Florida International University FIU Digital Commons

$4-1-2002$

\title{
Sugar and coffee: a history of settler agriculture in nineteenth-century Liberia
}

William Ezra Allen

Florida International University

DOI: $10.25148 /$ etd.FI13101591

Follow this and additional works at: https://digitalcommons.fiu.edu/etd

Part of the African History Commons

\section{Recommended Citation}

Allen, William Ezra, "Sugar and coffee: a history of settler agriculture in nineteenth-century Liberia" (2002). FIU Electronic Theses and Dissertations. 1068.

https://digitalcommons.fiu.edu/etd/1068

This work is brought to you for free and open access by the University Graduate School at FIU Digital Commons. It has been accepted for inclusion in FIU Electronic Theses and Dissertations by an authorized administrator of FIU Digital Commons. For more information, please contact dcc@fiu.edu. 


\section{FLORIDA INTERNATIONAL UNIVERSITY}

Miami, Florida

SUGAR AND COFFEE: A HISTORY OF SETTLER AGRICULTURE IN NINETEENTH-CENTURY LIBERIA

A dissertation submitted in partial fulfillment of the

requirements for the degree of

DOCTOR OF PHILOSOPHY

in

HISTORY

by

William Ezra Allen 
To: Dean Arthur W. Herriott

College of Arts and Sciences

This dissertation, written by William Ezra Allen, and entitled Sugar and Coffee: A History of Settler Agriculture in Nineteenth-Century Liberia, having been approved in respect to style and intellectual content, is referred to you for judgment.

We have read this dissertation and recommend that it be approved.

Edmund Abaka

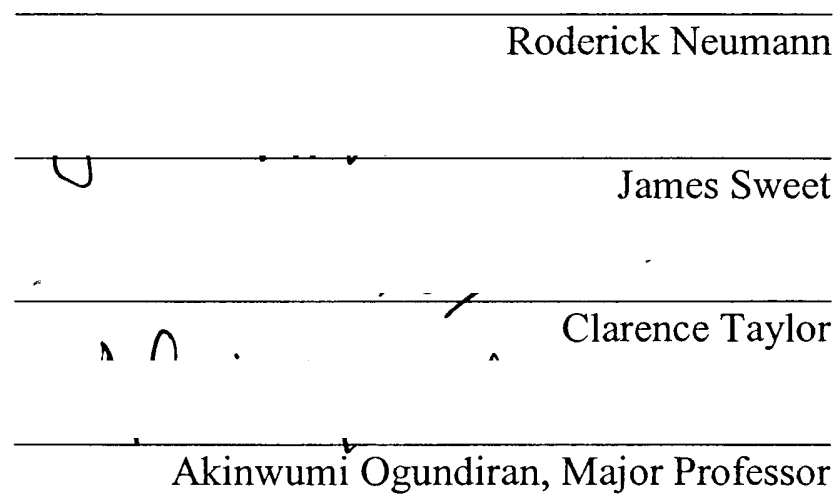

Date of Defense: April 1, 2002

The dissertation of William Ezra Allen is approved.

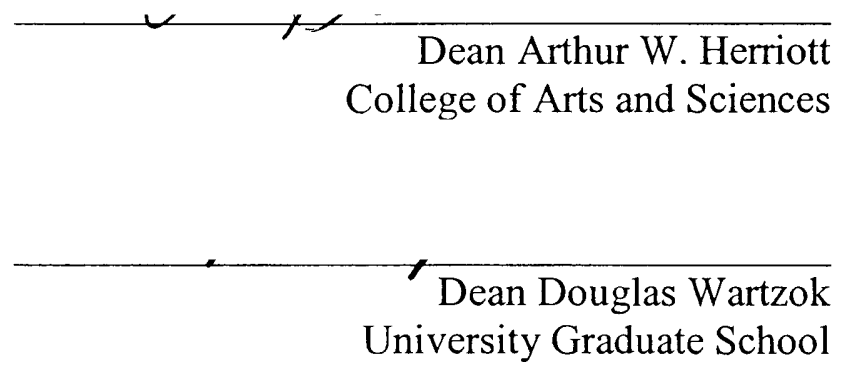

Florida International University, 2002 
(C) Copyright 2002 by William Ezra Allen

All rights reserved. 


\section{DEDICATION}

This dissertation is dedicated to the people of my hometown Palala, Liberia, and to the memories of my father, Nathaniel G. A. Allen, and Christopher Gray, friend and academic advisor. 


\section{ACKNOWLEDGMENTS}

I thank the numerous persons and institutions that contributed to make this dissertation possible. Research funding for the dissertation was provided by the Rockefeller Foundation African Dissertation Internship Awards. My profound appreciation goes to the faculty, staff and students of the University of Liberia who were always favorably inclined to offer assistance during my research in 1999. Particularly, I thank the instructors of the Demographic Unit at the University of Liberia (including Dr. Al-Hassan Conteh and Mr. Kaye) for their valuable support. I also express my gratitude to my Liberian friends, such as Alaric Tokpa and Augustine Toure, for their encouragement. Thanks are equally due to "Ma Jesse" and her family for the tasty Liberian dishes (e.g., dry-rice and fried fish) I ate at her home when I returned from the field.

I would also like to acknowledge the generous financial contribution, in the form of tuition wavers, that I received from the Department of History of Florida International University (FIU). Most certainly, I would not be writing these acknowledgments at this time had it not been for the kindness of Professor Chris Gray, one of the persons the dissertation is dedicated to. Chris was my classmate, friend, professor and academic advisor. He encouraged me to enroll in the doctorate program at FIU in the Fall of 1996 where he had recently been hired as an assistant professor in the history department. $\mathrm{He}$ guided me through the early, difficult years of graduate school and closely supervised the writing of my dissertation proposal--even as he lay tragically ill, facing imminent death. 
He passed away on October 16, 2000. To his wife Kisanga and the children, who were my family away from home, I will always be grateful.

I thank all the following members of my Dissertation Committee for their unwavering support and guidance: Dr. Clarence Taylor, Dr. James Sweet, Dr. Edmund Abaka, Dr. Roderick Neumann and Dr. Akinwumi Ogundiran. Special thanks go to Dr. Ogundiran (my Major Advisor), who was thrust into the leadership role as a result of the untimely death of Chris. His counsel and supervision, at a very critical juncture of the dissertation-writing process, was admirable. I express my indebtedness to Professor John C. Yoder of Whitworth College in Spokane, Washington, who served as my unofficial Outside Reader (i.e., the Liberianist). Dr. Yoder patiently read all my initial drafts and made detailed comments and suggestions.

I owe the greatest debt to my family in Liberia and the United States for their tireless assistance and understanding. To Gormah Allen, my non-literate mother, who "scratched" the farm laboriously so I could go to the "Whiteman House" for an education, I say in Liberian parlance, “Old Ma, God will continue to bless you yaa!" Finally, I thank my wife, Denise, for her encouragement and steadfast support. Her experience and selflessness made my academic sojourn so much easier. 


\section{ABSTRACT OF THE DISSERTATION \\ SUGAR AND COFFEE: A HISTORY OF SETTLER AGRICULTURE IN \\ NINETEENTH-CENTURY LIBERIA}

by

William Ezra Allen

Florida International University, 2002

Miami, Florida

Professor Akinwumi Ogundiran, Major Professor

This dissertation is about commercial agriculture in nineteenth-century Liberia. Based primarily on the archives of the American Colonization Society (founder of Liberia), it examines the impact of environmental and demographic constraints on an agrarian settler society from 1822 to the 1890 s. Contrary to the standard interpretation, which linked the poor state of commercial agriculture to the settlers' disdain for cultivation, this dissertation argues that the scarcity of labor and capital impeded the growth of commercial agriculture. The causes of the scarcity were high mortality, low immigration and the poverty of the American "Negroes" who began to settle Liberia in 1822.

Emigration to Liberia meant almost certain death and affliction for many immigrants because they encountered a new set of diseases. Mortality was particularly high during the early decades of colonization. From 1822 to 1843 , about 48 percent of all immigrants died of various causes, usually within their first year. The bulk of the deaths is attributed to malaria. There was no natural increase in the population for this early 
period and because American "Negroes" were unenthusiastic about relocation to Liberia, immigration remained sparse throughout the century. Low immigration, combined with the high death rate, deprived the fledgling colony of its potential human resource, especially for the cultivation of labor-intensive crops, like sugar cane and coffee. Moreover, even though females constituted approximately half of the settlers, they seldom performed agricultural labor.

The problem of labor was compounded by the scarcity of draft animals. Liberia is in the region where trypanosomiasis occurs. The disease is fatal to large livestock. Therefore, animal-drawn plows, common in the United States, were never successfully transplanted in Liberia. Besides, the dearth of livestock obstructed the development of the sugar industry since many planters depended on oxen-powered mills because they could not afford to buy the more expensive steam engine mills.

Finally, nearly half of the immigrants were newly emancipated slaves. Usually these former bondsmen arrived in Liberia penniless. Consequently, they lacked the capital to invest in large-scale plantations. The other categories of immigrants (e.g., those who purchased their freedom), were hardly better off than the emancipated slaves. 


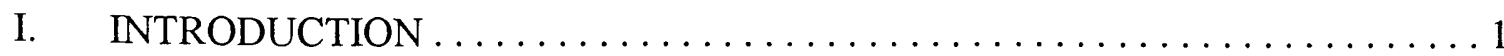

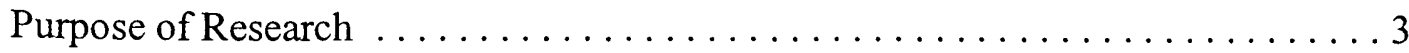

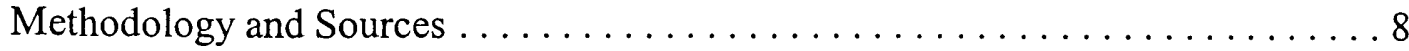

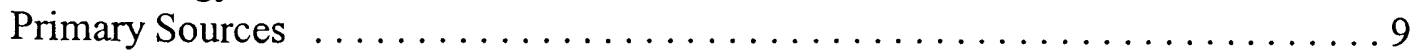

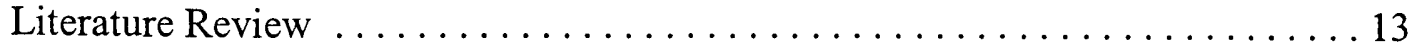

History of the Colonization Movement and the Founding of Liberia . . . . . . 13

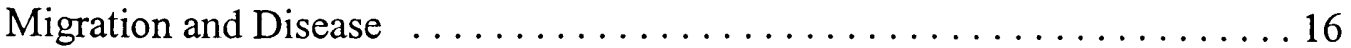

Supplementary Literature on Sugar and Coffee Production . . . . . . . . . 18

Liberian Agriculture . . . . . . . . . . . . . . . . . . . . . . . . . . . 19

The Motives for the Neglect of Agriculture . . . . . . . . . . . . . . 21

Situating Liberian Agriculture in the Context of West African History . . . . . . . 28

The Impact of Legitimate Commerce . . . . . . . . . . . . . . . 28

Probable Origins of the Assumption that Agriculture was Neglected .... . . 34

II AMERICO-LIBERIAN SETTLEMENT AND AGRICULTURAL ECOLOGY

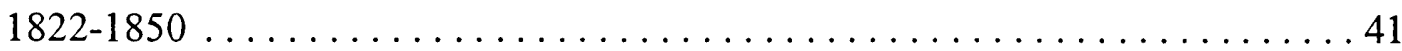

Establishment of the Liberian Settlement $\ldots \ldots \ldots \ldots \ldots \ldots \ldots \ldots \ldots \ldots . \ldots 4$

Formation of the American Colonization Society $\ldots \ldots \ldots \ldots \ldots \ldots 41$

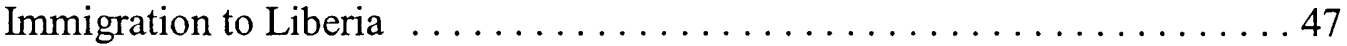

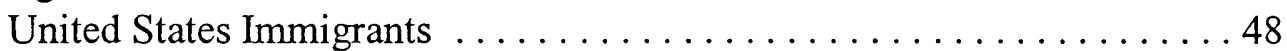

The Recaptured Africans or Liberated Africans . ............. 50

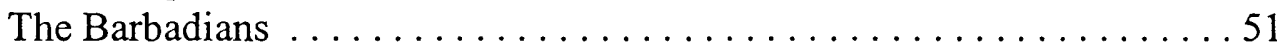

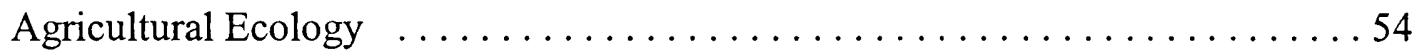

Diseases, Seasonality and Soil Quality . . . . . . . . . . . . . 54

From Towns to Farms: Settlement History and Agricultural Expansion . . . . . . 59

The Era of the Merchants . . . . . . . . . . . . . . . . . . . 59

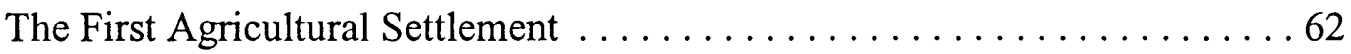

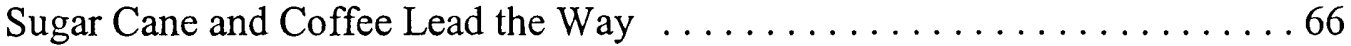

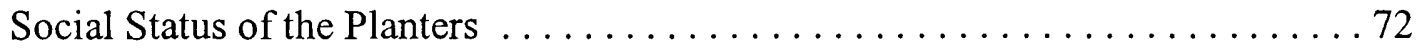

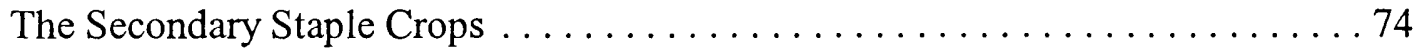

I. THE ERA OF SUGAR CANE AND SUGAR PRODUCTION, ca. 1850-1880s . 78 International Stimuli to Sugar Production in Liberia $\ldots \ldots \ldots \ldots \ldots \ldots . \ldots 78$ Factors of Production: Labor, Capital, Land and Entrepreneurship . . . . . . . 81 The Sugar Region of Liberia: St. Paul River and its "Few Facilities" . . . . . . . 85 "Intelligent Immigrations, A Little Heap of Money" . . . . . . . . . . . . . 92

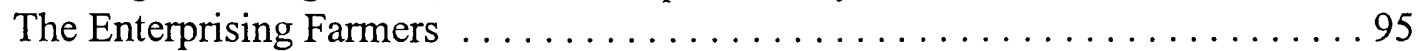

John B. Jordan: The Pioneer of Steam Sugar Cane Mill? . . . . . . . . . . . 97

Garret Cooper and Sons: A Family Affair . . . . . . . . . . . . . 98

William Anderson: The Heir Apparent . . . . . . . . . . . . . . . . 99 
Jesse Sharp: “An African Sugar Planter" . . . . . . . . . . . . . . . . . 103

L. L. Lloyd: Inefficient Entrepreneur or Victim of Unfortunate

Circumstances? . . . . . . . . . . . . . . . . . . . . . . . . . 104

Augustus Washington: The Man With "Scores of Irons in the Fire." . . . . 107

William Roe, Thomas Howland and M. T. Decoursey: Making Sugar

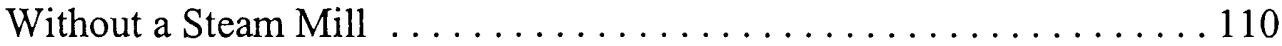

The Latecomers . . . . . . . . . . . . . . . . . . . . 113

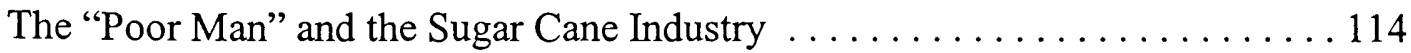

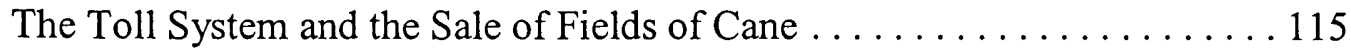

Costs of Investment: The Mills and Kettles . . . . . . . . . . . . . . . 118

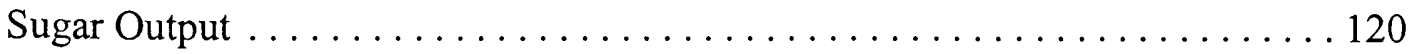

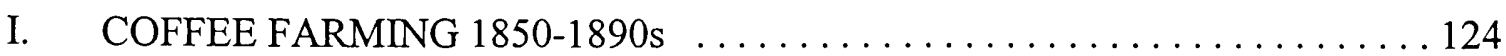

An Overview of Coffee Cultivation, 1850 to ca. $1860 \ldots \ldots \ldots \ldots \ldots \ldots \ldots$

The Coffee Huller, the Coffee Planters and the Coffee Regions . . . . . . . . . 128

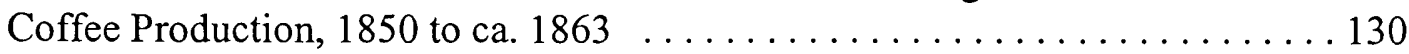

St. John Leads St. Paul . . . . . . . . . . . . . . . . . . . . 130

The Planters . . . . . . . . . . . . . . . . . . . . 132

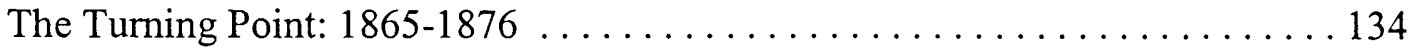

The "Morris Factor" ............................. 134

The Boom and the Decline 1870 s to 1890 s $\ldots \ldots \ldots \ldots \ldots \ldots \ldots \ldots \ldots \ldots$

The St. Paul Coffee Settlements . . . . . . . . . . . . . . . . . . . . . 147

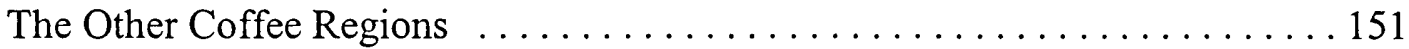

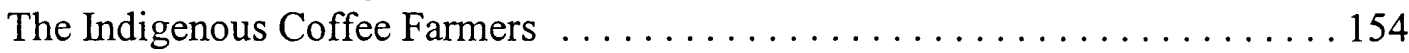

The Comparison ...................................... 157

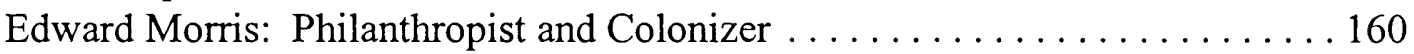

V. DISEASE, IMMIGRATION AND ADAPTATION $\ldots \ldots \ldots \ldots \ldots \ldots \ldots$

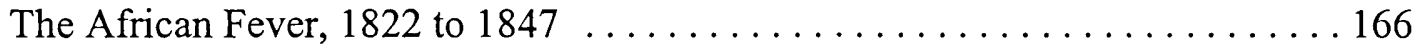

American Farmers Without Plows: "No animal labor to assist" . . . . . . . . . . 169

History of the Animal Disease: Trypanosomiasis . . . . . . . . . . . . 172

Patterns of Immigration: Low Immigration, High Non-Agricultural Laborers . 177

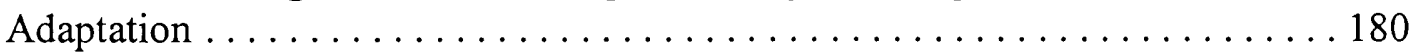

Genetic Adaptation, the Advent of Quinine and the Salubrious Interior . . . 180

VI. THE COLLAPSE AND DECLINE OF SUGAR AND COFFEE $\ldots . \ldots \ldots \ldots 189$

International Forces: Declining Prices $\ldots \ldots \ldots \ldots \ldots \ldots \ldots \ldots \ldots \ldots \ldots \ldots$

Foreign Competition . . . . . . . . . . . . . . . . . . . . . . . 191

Inadequate Technology . . . . . . . . . . . . . . . . . . . . . 194

VII. CONCLUSION: RETHINKING THE NOTION OF "NEGLECT" . . . . . . . . 202

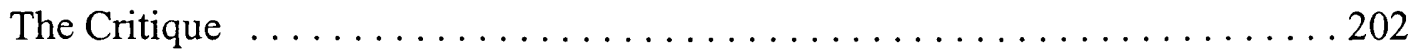

The Alternative Interpretation . . . . . . . . . . . . . . . . 206 


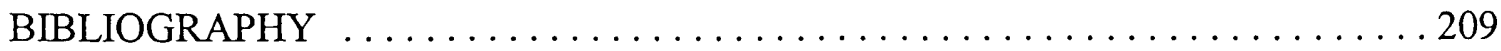

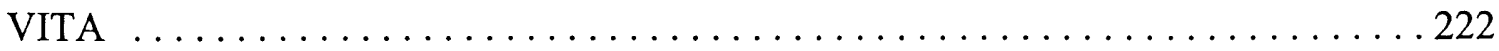




\section{LIST OF FIGURES}

FIGURE

PAGE

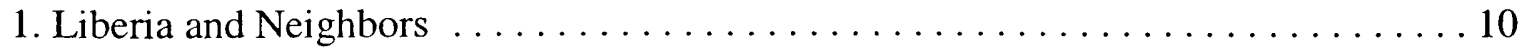

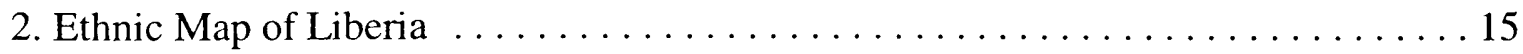

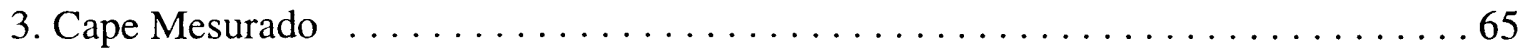

4. Map of Liberia with St. Paul River Settlements $\ldots \ldots \ldots \ldots \ldots \ldots \ldots$

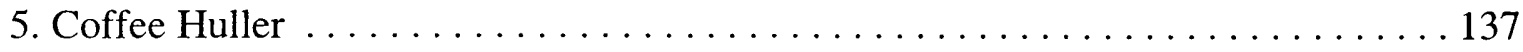

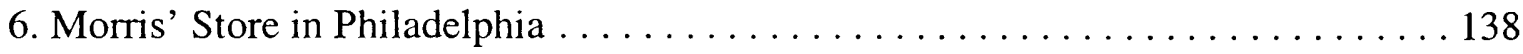

7. Liberian Products Palm Oil \& Palm Kernel in Round Glass Jars ... . . . . . . . 139

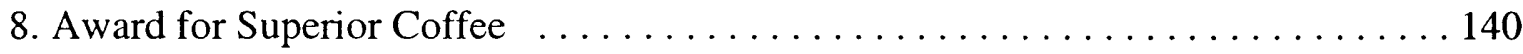

9. Award: Superior Coffee and Palm Soap $\ldots \ldots \ldots \ldots \ldots \ldots \ldots \ldots \ldots \ldots \ldots \ldots$ 


\section{CHAPTER I}

\section{INTRODUCTION}

Yet the reasons for this apathy among Americo-Liberians for agriculture, which prevailed up to the early 1870 's, were not far to seek. The majority of them being newly emancipated slaves, who had in servitude in America been used to being forced to work, erroneously equated their newly won freedom with abstinence from labor.

-M. B. Akpan ${ }^{1}$

This is a dissertation about the history of commercial agriculture in nineteenthcentury Liberia. According to the historiography, the free black immigrants from the United States, who settled in what is now Liberia throughout the nineteenth century, disdained agricultural labor. As a result, for a greater part of the century, they failed to produce tropical staple commodities such as coffee and sugar, that could have been sold profitably overseas. ${ }^{2}$ It is alleged that the immigrants had what was needed to become successful planters. Liberia, founded by the American Colonization Society (ACS) in 1822 , was located in luxuriant tropical forest on the west coast of Africa. It was richly endowed with agricultural potential, including abundant farmland and plenty of rainfall. The soil was fertile and some of the principal tropical goods demanded by European and

\footnotetext{
M. B. Akpan, "The Liberian Economy in the Nineteenth Century: The State of Agriculture and Commerce," Liberian Studies Journal 6, 1 (1975): 1-24

${ }^{2}$ For example, see, Ibid; J. Gus Liebenow, Liberia: The Evolution of Privilege (Ithaca: Cornell University Press, 1969), 12-13; George W. Brown, An Economic History of Liberia (Washington, D. C.: Associated Press, 1941), 139-140; Amos Sawyer, The Emergence of Autocracy in Liberia. Tragedy and Challenges (San Francisco: Institute for Contemporary Studies, 1992), 163-164.
} 
American consumers, like coffee, thrived undomesticated in the lush Liberian forest. ${ }^{3}$

Every colonist had access to sufficient land. Officials of the ACS distributed land generously and almost free of charge to the immigrants. Each family was given one acre of town lot and 5 acres of farmland for the father, 2 acres for the mother and one acre for each child. No family was allowed more than 10 acres, but those who wanted to establish plantations received up to 50 acres of land outside of the limits of the town. Additional land could be acquired through purchase and service in the militia. ${ }^{4}$

Scholars claim that in spite of this comparative advantage, the Liberian colonists showed very little interest in cultivation. Instead, the majority chose commerce over agriculture. The wealthier immigrants, who had the resources to invest in agriculture, bought African products including palm oil and camwood from the local people and sold them to European and American traders on the Liberian coast. In return, the Liberian traders bought Western merchandise (e.g., textiles) from the foreigners and bartered them for more African commodities. Some of the merchants became quite prosperous in the transatlantic trade. They established huge warehouses and bought ships that plied the West African littoral buying palm oil and other goods for shipment to Europe. Sometimes the Liberian vessels made the transatlantic voyage to Europe. ${ }^{5}$

Historian M. B. Akpan has argued that the immigrants (or Americo-Liberians as they later called themselves) remained staunchly opposed to agriculture until Liberian

\footnotetext{
3Akpan, "The Liberian Economy."

${ }^{4}$ Amos Sawyer, The Emergence of Autocracy in Liberia, 123.

${ }^{5}$ Dwight N. Syfert, "The Liberian Coasting Trade, 1822-1900," Journal of African History 13, 2 (1977): 217-235.
} 
maritime trade began to decline in the 1870 s. With the collapse of trade, the AmericoLiberians had very few career alternatives. It was only then, according to Akpan, that some of the former merchants turned their attention to the cultivation of sugar cane and coffee. ${ }^{6}$ Thus, Akpan concluded (and most scholars would agree) that "the greatest bane of agriculture among the Americo-Liberians was the mania for trade."7

In addition to the alleged distaste for farming, scholars usually cite other reasons for the failure of the Americo-Liberians to cultivate export crops. The lack of capital, the difficult in adjusting to the unique challenges that farming in the tropical Liberian environment presented and an unusually high mortality rate caused by malaria; the high death rate deprived the immigrant community of labor and deterred many from agriculture. ${ }^{8}$ Notwithstanding the obstacles, these scholars contend that it was the Americo-Liberians' contempt for agriculture that prevented them from cultivation in the first place. ${ }^{9}$ Akpan, for instance, claimed that environmental constraints simply "hardened" the Americo-Liberians' distaste for agriculture. ${ }^{10}$

\section{$\underline{\text { Purpose of Research }}$}

My research, which is based primarily on the available archival and secondary sources, has led me to discover that the conventional explanation for why the production

\footnotetext{
${ }^{6}$ Akpan, "The Liberian Economy," 17.

${ }^{7}$ Ibid., 7; Brown, An Economic History of Liberia, 164-165; Liebenow, Liberia: The Evolution of Privilege, 12-13.

${ }^{8}$ Akpan, "The Liberian Economy," 5-6; Liebenow, Liberia: The Evolution of Privilege, 12-13.

${ }^{9}$ Ibid.; George W. Brown, An Economic History of Liberia, 139-140.

${ }^{10}$ Akpan, "The Liberian Economy," 5-6.
} 
of export crops was mostly unsuccessful in the nineteenth century is highly questionable. First, contrary to the allegation that the Americo-Liberians shunned agriculture, archival sources from the nineteenth century indicate many immigrants went directly into agriculture upon their arrival in Liberia. The archival evidence will show, for example, that in 1825 (roughly three years after the Colony of Liberia was founded) the first agricultural community was organized by a group of newcomers from Virginia. The immigrants insisted that they were farmers and did not want to live in Monrovia, the commercial and administrative capital. Besides, the archives prove that a number of agricultural associations were founded in the $1820 \mathrm{~s}$ and $1830 \mathrm{~s}$.

The second reason to question the assumption that agriculture was neglected is based on data found in secondary sources. There are some doubts that the Liberian soil was ideally suitable for commercial agriculture as is claimed by scholars. Studies have generally confirmed that the quality of humus in African soil tends to be marginal. For example, the geographers, Peter Ahn and Hans Ruthenberg attributed this marginality to the loss of humus due to the leaching of the topsoil by tropical rainfall. ${ }^{11}$ Thus, the conclusion by historians Paul Bohannan and Philip Curtin that compared to the United States "African soils are indeed poor," is no surprise. ${ }^{12}$ The studies demonstrate that the effects of leaching are more severe in regions with a high concentration of laterite or small stones in the soil. ${ }^{13}$ Liberian soils must be particularly deficient in nutrients

\footnotetext{
${ }^{\Pi}$ Peter Ahn, West African Soils (Oxford, UK: Oxford University Press, 1970), 84-98; Hans Ruthenberg, Farming Systems in the Tropics (Oxford: Clarendon Press, 1971), 8-12.

${ }^{12}$ Paul Bohannan and Philip Curtin, Africa and Africans (Prospect Heights, IL: Waveland Press, 1995), $23-$ 24.

${ }^{13}$ Ahn, West African Soils, 84-98.
} 
because geographer Stefan Von Gnielinski has observed that 75 percent of Liberian land consists of lateritic soil and is "heavily leached." 14 Furthermore, until approximately the 1840s, most of the lands available to the Liberian colonists for agriculture were located on the Atlantic coast where the first settlements had been established. The Liberian coast consists of hilly, sandy and marshy lowlands. Such land is hardly ever described as "fertile," especially for the cultivation of the coffee plant which is less tolerant to the heavy rain that drenches the Atlantic littoral. ${ }^{15}$ Coffee trees thrive far better on elevated, heavily forested land with moderate rainfall; the forest canopy provides shade that is vital for the prosperity of the plant. ${ }^{16}$

Finally, the facts in the primary sources are obviously at variance with Akpan's claim that the majority of Americo-Liberians became cultivators only after they lost their privileged positions in the transatlantic trade in the 1870s. The evidence from the archives is unequivocal: Although many farmers occasionally doubled as traders, none of the ten or more prominent sugar cane and coffee planters were former merchants who turned to agriculture in the 1870 s. In fact, the boom years for the overseas trade in sugar and sugar cane cultivation were in the 1860 s; the sugar industry began its decline in the mid 1870 s and never recovered. As for coffee, by the 1870 s the leading farmers had been growing the crop since the $1850 \mathrm{~s}$. Furthermore, some of the coffee planters, who became

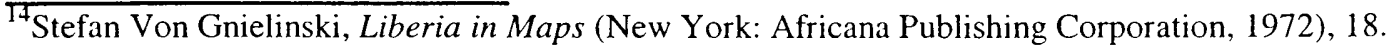

${ }^{15}$ Sugar cane may have thrived better than coffee in the marshy coastal lands. But the excessive rains (many times more than the 60 " suitable for the growth of the cane and temperatures of more than 80 degrees Fahrenheit) would have adversely affected the sugar cane. For discussion on the conditions for growing sugar cane, See, J. Carlyle Sitterson, Sugar Cane Country: The Cane Sugar Industry in the South, $1753-$ 1950 (Kentucky: University of Kentucky, 1953), 13.

${ }^{16}$ Compuzano Andrés Uribe, Brown Gold: The Amazing Story of Coffee (New York: Random House, 1954).
} 
prosperous in the last quarter of the century, emigrated between 1869 and early 1870 and went directly into coffee production.

My aim is to write an alternative history of commercial agriculture in nineteenthcentury Liberia. In Liberia, the words "plantation" and "farm" were used interchangeably. The reference to a plantation did not entail the use of slave labor or a "self-sustaining" population, all of which are historically associated with the plantation. ${ }^{17}$ Quite often, the Americo-Liberians used the word plantation to refer to an area (normally 3 acres and above) where staple crops (e.g., coffee) were cultivated for local and export sale. Labor for the plantation was customarily recruited on the basis of prearranged bargains for wages. Food for the household, according to the Liberian usage, was produced in gardens or on farms. ${ }^{18}$ Generally, the plantation or farm was much larger than the gardens.

In this dissertation the expressions "commercial agriculture" and "plantation agriculture" will denote the cultivation of one or two staple crops (also referred to as primary crops) for local or export sale. For this study, the emphasis is on cultivation for export trade. Sugar cane and coffee were the two staples that the Americo-Liberians grew successfully in the 1800 s. Successive attempts to produce other tropical crops eventually faltered. Therefore, the title of this dissertation, "Sugar and Coffee: A History of Settler Agriculture in Nineteenth-century Liberia," is the story of the Americo-Liberians' experience with plantation agriculture.

\footnotetext{
${ }^{17}$ Philip D. Curtin, The Rise and Fall of the Plantation Complex: Essays in Atlantic History (New York: Cambridge University Press, 1990), 10-13.

${ }^{18}$ For examples of the usages, see, Jehudi Ashmun, The Liberian Farmer; Or Colonists Guide to Independence and domestic Comfort (Philadelphia: Kaswell and Barrington, 1835).
} 
My research will contribute to efforts aimed at writing the history of commercial agriculture in nineteenth-century Liberia. Principally, it provides a new interpretation on the topic, focusing on areas such as the impact of diseases on agriculture and the scarcity of labor and capital which have generally been omitted from previous analyses. In addition, my research provides an explanation for the failure of agriculture in the period prior to the mid-nineteenth century (in spite of the pioneering efforts such as the formation of agricultural associations). Previous scholarship has been directed almost entirely to second half of the century, the era of the export trade in sugar and coffee. By expanding the scope of the inquiry, this dissertation will offer fresh, additional details on the history of commercial agriculture.

This dissertation also provides a local perspective on the lively debate that has evolved in West African history over the impact of the new commerce that replaced the slave trade in the $1800 \mathrm{~s}$. Basically, one school of thought maintains that the inception of the commerce in non-slave commodities after the abolition of the slave trade resulted in a crisis (e.g., A. G. Hopkins). The other school argues that the transition was made without any major crisis (e.g., Ralph Austen). ${ }^{19}$ A number of chapters in an edited text by Robin Law, provides localized perspectives to both sides of the debate. ${ }^{20}$ My study might also provide some additional local perspective.

\footnotetext{
${ }^{\Gamma 7}$ For a summary of the arguments see, A. G. Hopkins, "Economic Imperialism in West Africa: Lagos, 1880-1892," Economic History Review 21 (1968): 580-606; Ralph A. Austen, "The Abolition of the Overseas Slave Trade: A Distorted Theme in West African History," Journal of the Historical Society of Nigeria 5 (1970): 257-274); J. F. A. Ajayi and Ralph A. Austen, "Hopkins on Economic Imperialism in West Africa," Economic History Review 25 (1972): 303-306.

${ }^{20}$ Robin Law, From Slave Trade to 'legitimate'commerce: The commercial transition in nineteenth-century West Africa (New York: Cambridge University Press, 1995).
} 


\section{Methodology and Sources}

I have adopted a research methodology that is usually associated with the historical approach promoted by the journal Annales, which was founded by Lucien Febvre and Marc Bloch in 1929. Specifically, this dissertation draws upon the concept of la longue durée articulated by Fernand Braudel, a scholar of the Annales paradigm. Essentially, the principle of la longue durée method entails historical research that covers a period of much longer duration, usually a century or more. La longue durée is the opposite of the traditional historical research that explains causes mainly by studying events. $^{21}$

There are several reasons why la longue durée approach is useful to this study. Because historical sources are scarce, la longue durée allows for the examination of a larger "section" of the Liberian past which enables the researcher to discern "pieces of history" over a wider period. Event-centered history, with its focus on particular occurrences, is incapable of accomplishing this. Previous studies of the history of commercial agriculture centers almost exclusively on the big event, that is, the beginning of the overseas trade in second half of the 1800s. Very seldom do the analyses include the experiences from the earlier era. The apparent justification for the exclusion is that nothing essential was accomplished in this epoch. ${ }^{22}$ By eliminating the early era, scholars removed a critical "piece of history" from the analysis. The methodology I have chosen, that is la longue durée, will include all the documented aspects of the early Liberian

\footnotetext{
${ }^{21}$ For a discussion on the concept of la longue durée and the Annales historical method see, Fernand Braudel, On History, trans. Sarah Matthews, (Chicago: The University of Chicago Press, 1980); T. Stoianivich, French Historical Method: The Annales Paradigm (Ithaca: Cornell University Press, 1976).

${ }^{22}$ See Akpan, " The Liberian Economy in the Nineteenth Century," 6.
} 
settlements that relate to commercial agriculture during the first half of the century. It will demonstrate, for example, that the "pieces of history" converged and led to the production of staple crops for export.

\section{Primary Sources}

Eyewitness accounts from the nineteenth century pertaining to Liberian history in general are scarce. The primary and secondary sources directly related to the subject of commercial agriculture in Liberia are even more difficult to find. In this section, I will describe the archival materials that I used in my dissertation. Available information on sugar cane and coffee production is very scanty. For example, data on total acreage cultivated, the cost of investment, expenditures, quantities exported and revenues from sale are either unavailable or mostly incomplete. Information in the Census of 1843 , the only national enumeration for the century, is not very useful as far as agriculture is concerned. $^{23}$ At the time of the census, neither coffee nor sugar was sold abroad. Outside of the Census of 1843 , there is no national data on deaths, births and marriages, and biographical information on the settlers is very fragmentary. In short, there is no detailed account from the nineteenth century on the history of commercial agriculture.

Being aware of the paucity of primary sources, I included a fieldwork component in my research proposal which was intended to collect oral traditions. ${ }^{24}$ Unfortunately,

\footnotetext{
${ }^{23}$ The Census was conducted by the United States Government. U. S. Congress, Senate, U. S. Navy Dept., Tables Showing the Number of Emigrants and Recaptured Africans Sent to the Colony of Liberia by the Govt. of the United States. A Census of the Colony, (Sept., 1843 Senate Document no. 150, $28^{\text {th }}$ Cong., $2^{\text {nd }}$. Session, 1845), (hereafter The Census).

${ }^{24} \mathrm{Jan}$ Vansina, a distinguished pioneer in oral research in Africa, makes a distinction between oral traditions and oral history. The latter he calls contemporary accounts which "occurred during the lifetime of the informants." On the other hand, historical accounts that "have passed from mouth to mouth, for a period beyond the lifetime of the informants" is oral traditions. In this sense, I was attempting to collect oral
} 
the interviews for the oral traditions were discontinued shortly afterward. The decision to terminate the interviews centered around concerns for my safety and the hazardous conditions of traveling in Liberia at the time. From late 1989 through 1996, Liberia was embroiled in a civil war that unleashed violence unprecedented in its history. By 1997 the fighting had ended and a new government was elected and installed the following year. It was the general expectation that the inauguration of the civilian government would restore peace and security to Liberia. Encouraged by these signs and reassured by my contacts at the University of Liberia, I wrote the proposal to go to Liberia. (For a contemporary map of Liberia, see Figure 1.)

Upon my arrival in Liberia in 1999, it became immediately obvious that although the war had ended, Liberia was dangerous and unsafe. Ex-combatants and government soldiers roamed the country, harassing and threatening the population. There were constant reports of killings by soldiers, none of which seems to have ever been investigated. A sense of lawlessness prevailed. Besides these threats, free movements were severely restricted by the numerous "security checks-points" and the poor conditions of many of the roads. Several of my interviews were canceled or postponed either because roads were impassable or due to the long delays at the check-points. Because of these restrictions and out of concern for my safety, I eventually gave up the oral research. ${ }^{25}$ I spent the rest of the time in Liberia at the National Archives in Monrovia,

tradition since the information I was interested in originating in the nineteenth century. Jan Vansina, Oral Tradition as History (London: James Curry, 1985), 12-13.

${ }^{25}$ A detailed account of the atrocities committed throughout the civil war and leading to the election of 1997 is found in Stephen Ellis, The Mask of Anarchy: The Destruction of Liberia and the Religious Dimension of an African Civil War (New York: New York University Press, 1999), esp. 312-316. 
the capital, where life was relatively more secure. Occasionally-whenever it seemed safe to travel-I toured the sites and settlements where coffee and sugar cane were cultivated in the 1800 s.

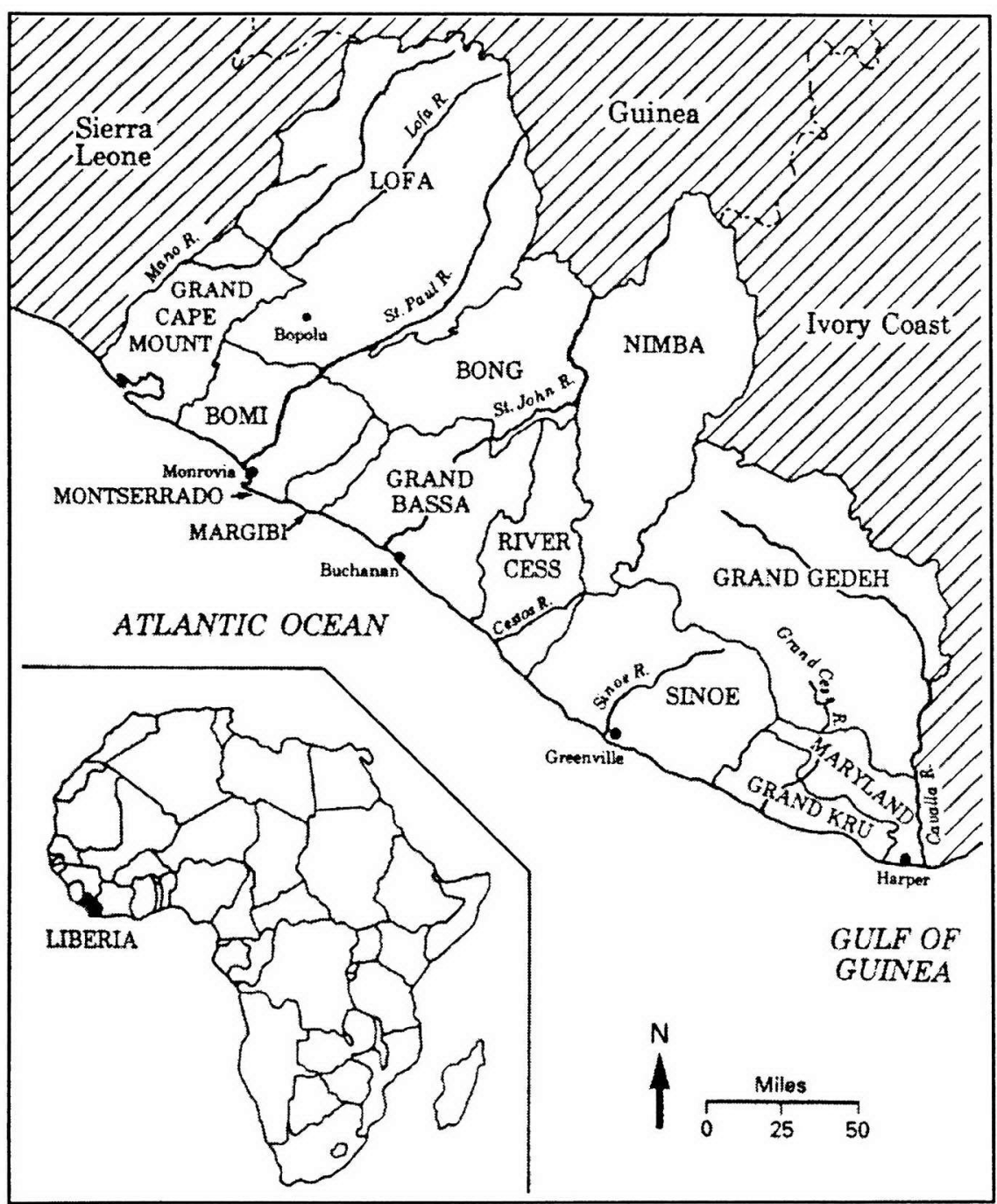

Figure 1. Liberia and Neighbors. (Reprinted by permission of Indiana University Press, Liebenow, 1987.) 
With the elimination of the oral interviews, the research for the dissertation was based largely on the archives of the ACS and a small collection of narratives from the nineteenth century. The archives of the ACS consist chiefly of administrative records prepared by officials of the ACS in Liberia, who submitted periodic reports to the organization in the United States. After the Americo-Liberians declared their independence from the organization in 1847 , the new government continued to send the dispatches to the ACS.

There are two principal documents in the archives, the "Annual Reports" and the "African Repository and Colonial Journal," later changed to the "African Repository." The Annual Reports consist mainly of official policies and administrative matters, while the African Repository contains general information about the immigrants and Liberia. Both works were published in the United States by the ACS. In 1822, the first Annual Report was distributed and continued to be published until 1912 when the ACS closed its offices permanently. The first edition of the African Repository and Colonial Journal was published in 1825 . It was issued to subscribers monthly, and subsequently quarterly. In 1892, the ACS discontinued publication of the African Repository and for the rest of the century printed instead, the "Liberia Bulletin." Nearly all the editions of the Annual Reports and African Repository are available in the Microform Section of Florida International University Library.

The small collection of books and manuscripts written in the 1800s also contains useful information on the history of commercial agriculture. Without doubt, the prime text in this selection (and perhaps in the entire primary source) is the correspondence 
between the Liberian immigrants and their former masters in the United States. A majority of the tiny population of free blacks, who were literate, had communicated with had their former masters. In their letters, the immigrants often wrote about farming in Liberia. ${ }^{26}$ Finally, information on sugar cane and coffee cultivation can be gleaned from a handful of texts prepared in the nineteenth century. They include a biography, manuals on farming and several narratives written by visitors to Liberia. ${ }^{27}$ My secondary sources are discussed below.

\section{Literature Review}

\section{History of the Colonization Movement and the Founding of Liberia}

For convenience, the main body of literature used to reconstruct the history of plantation agriculture can be divided into four broad themes: History of the Colonization Movement and the Founding of Liberia, Migration and Diseases, External Literature on Sugar and Coffee, and Liberian Agriculture. Account of the colonization movement and the founding of Liberia is available in most standard textbooks on Liberian history. Amos Sawyer's "The Emergency of Autocracy in Liberia" and J. Gus Liebenow's "Liberia: The Evolution of Privilege" are two of the best sources among the standard texts. Liebenow (deceased) and Sawyer, both political scientists, provide a lengthy detail

\footnotetext{
${ }^{26}$ The letters are published in two edited texts by Bell I Wiley and Randall M. Miller. Wiley's work contained all or most of the known correspondents. Miller's book contained the letters of one immigrant family. Bell I Wiley, ed., Slaves No More: Letters from Liberia, 1833-1869 (Lexington: The University of Kentucky, 1980); Randall M. Miller, ed., Dear Master: Letters of a Slave Family (Athens: The University of Georgia Press).

${ }^{27}$ The leading texts in this category are: Ralph Randolph Gurley, Life of Jehudi Ashmun: Late Colonial Agent in Liberia (New York: Robinson \& Franklin, 1839); Ashmun, The Liberian Farmer; J. W. Lugenbeel, Sketches of Liberia: Comprising A Brief Account of the Geography, Climate, Productions, and Diseases, of the Republic of Liberia (Washington: C. Alexander, Printer, 1850); Helen Cross Knight, The New Republic (Boston: Massachusetts Sabbath School Society, 1851).
} 
on the evolution of the Liberian state and the consolidation of Americo-Liberian authority over the various ethnic groups. ${ }^{28}$ (See Figure 2.)

The most detailed account of the colonization movement is P. J. Staudenraus' "The African Colonization Movement: 1816-1965." Some of the principal themes include the rise of the colonization movement in the United States in the late 1700 s, the founding of the ACS, the establishment of Liberia and some of the major problems that the immigrants encountered in Liberia. ${ }^{29}$ Staudenraus' book is well documented. His bibliography leads the reader to the principal archives and secondary sources on the topic. In addition to Staudenraus' book, the publications by Edwin Redkey, Richard West, Floyd Miller and Penelope Campbell offer additional information on the Liberian colonization process. ${ }^{30}$ Redkey's "Black Exodus" traces the major political and social forces in the United States (the push-factor) that motivated free blacks to consider emigration to Liberia and other parts, such as Haiti. West discussed (among others) the rise of the abolition movement in England in the late eighteenth century, which led to the founding of the first colony in Sierra Leone for free blacks from London in 1787. In

\footnotetext{
${ }^{28}$ C. E. Zamba Liberty gave a scathing criticism of Liebenow's book. Liberty charged that Liebenow ascribed the problems in Liberia solely to the rulership of the Americo-Liberians. He called Liebenow's analysis of the Liberian problem "conspiratorial and monocausal." C. E. Zamba Liberty, "Growth of the Liberian State: An analysis of its Historiography" (Ph.D. diss., Stanford University, 1977), 29-30.

${ }^{29}$ P. J. Staudenraus, The African Colonization Movement: 1816-1865 (New York: Octagon Books, 1980).

${ }^{30}$ Edwin S. Redkey, Black Exodus: Black Nationalism and Back-to-Africa Movements, 1890-1910 (New Haven, CT.: Yale University Press, 1969): Richard West, Back to Africa: A History of Sierra Leone and Liberia (London: Jonathan Cape, 1970); Floyd Miller, The Search for a Black Nationality: Black Emigration and Colonization, 1787-1863 (Chicago: University of Illinois, 1975); Penelope Campbell, Maryland in Africa: The Maryland State Colonization Society 1831-1857 (Urbana: University of Illinois, 1971).
} 


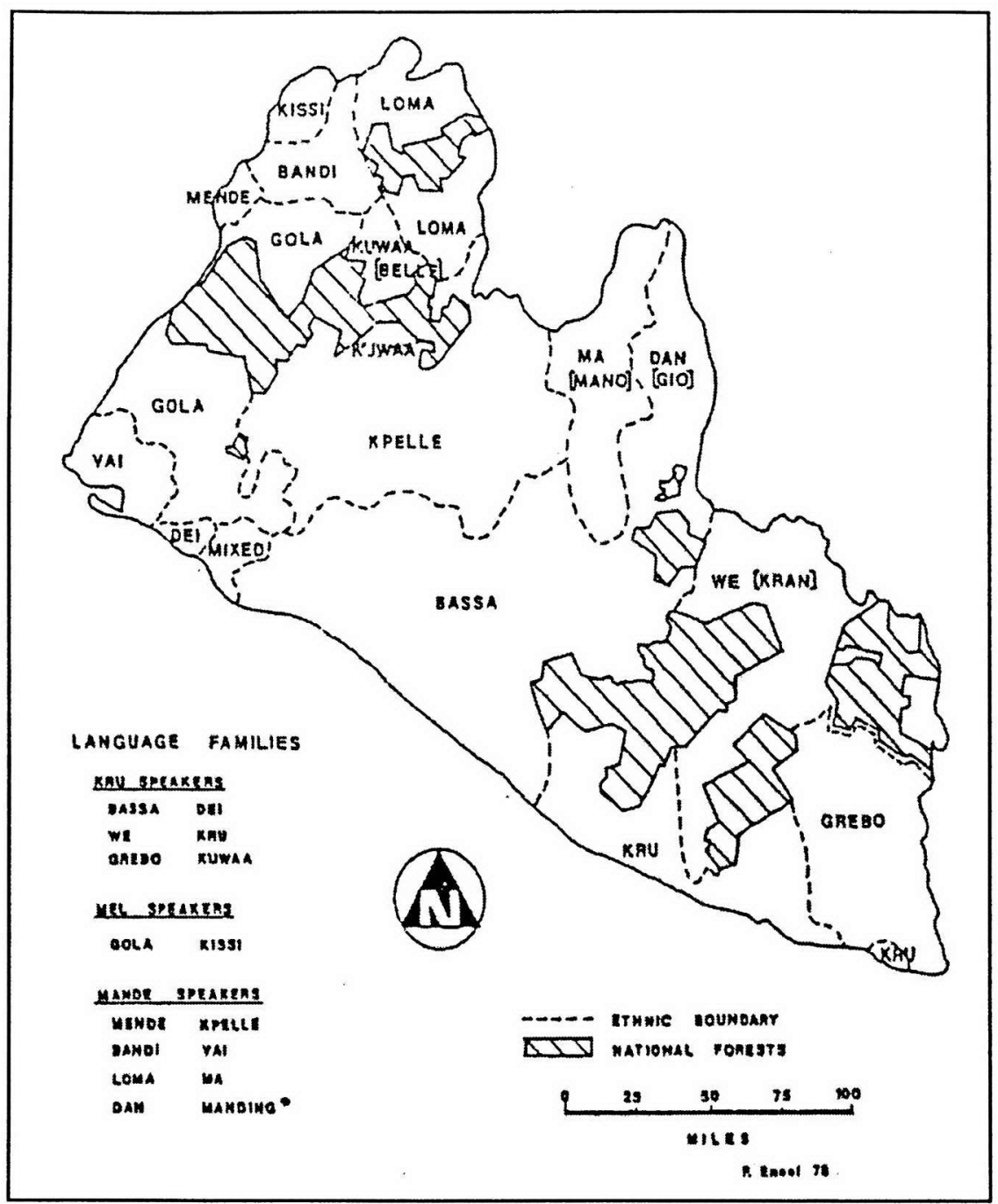

Figure 2. Ethnic Map of Liberia. (Reprinted by permission of Cornell University Press. Liebenow, 1969.) 
Miller's book, an account of the debates between the supporters and critics of the colonization movement in the United States is given. And finally, Penelope Campbell's is one of the few narratives on the history of "Maryland in Africa." The Colony of Maryland was founded by the American state of Maryland at the eastern extreme of the Liberian coast in 1835. For a little more than two decades, Maryland in Africa existed as an "independent state" although the "nation" owed its survival almost exclusively to the parent body in the United States. It was eventually annexed by the Republic of Liberia in 1857. Besides reconstructing the history of Maryland, Campbell's book is particularly useful because it presents a local American perspective (i.e., the State of Maryland as opposed to the ACS which was a national body) on the colonization movement.

\section{Migration and Disease}

There is an impressive list of books and manuscripts on the topic of migration and disease. Regrettably, not many of them are about migration and disease among the Liberian colonists. Historian Antonio McDaniel's publication of 1993 offers the most comprehensive analysis on the high death rate that the Liberian immigrants experienced. His analysis, which is drawn from the data in the Census of 1843 , covers a very small section of the century. ${ }^{31}$ One conclusion by McDaniel, which is very relevant for this study, is the extremely high death rate of the Liberian immigrants. In the words of McDaniel, "Life expectancy at birth was less than three years ... I am unaware of any other life tables that show such an extraordinary level of mortality." 32 This was a

\footnotetext{
${ }^{31}$ Antonio McDaniel, Swing Low, Sweet Chariot: The Mortality Cost of Colonizing Liberia in the Nineteenth Century (Chicago: University of Chicago, 1993).

${ }^{32}$ Ibid., 77.
} 
disastrous loss, but it was even more devastating, I will argue, because of the ultimate impact on agriculture. Another valuable publication on mortality of the Liberian immigrants is found in the Journal of African History which was written by the late Tom Shick. ${ }^{33}$ His work is an interpretative analysis of the data on mortality.

Theories on the general topic of migration and disease were selected from the studies of the following authors: Philip Curtin, William McNeil, R. Hoeppli and Emilo Pampana. ${ }^{34}$ Curtin's central contribution is his comparative study of the mortality rate of British soldiers in foreign lands (e.g., tropical Africa) and the English citizens that remained at home. His "relocation cost" analysis is helpful for understanding the causes of the devastating mortality rate in Liberia. McNeil and Hoeppli cover the general history of diseases. McNeil emphasizes the relationship between migration and diseases, while Hoeppli examines early accounts of the probable role of the transatlantic slavery in the transmission of some killer-diseases like malaria. The last book in this category, Emilo Pampana's text, is essential for his discussion of the history of malaria, the pathology of the infection, its diffusion and the attempts made by science to eliminate it. Pampana's work was very useful because it included the basic knowledge needed to understand the deadly malaria that plagued the Liberian immigrants.

\footnotetext{
${ }^{33}$ Tom Shick, "A Quantitative Analysis of Liberian Colonization from 1820 to 1843 with Special Reference to Mortality." Journal of African History 12, 1 (1971): 45-59.

${ }^{34}$ Philip Curtin, Death by Migration: Europe's Encounter With the Tropical World in the Nineteenth Century (New York: Cambridge University Press, 1989); Disease and Empire: The Health of European Troops in the Conquest of Africa (New York: Cambridge University Press, 1998); William McNeil, Plagues and People (New York: Anchor Books, 1998); R. Hoeppli, Parasitic Diseases in Africa and the Western Hemisphere: Early documentation and Transmission by the Slave Trade (Verlag Fürrecht Und Gesellschaft AG. Basel, 1969); Emilio Pampana, A Textbook of Malaria Eradication (London: Oxford University, 1969).
} 
This section was included primarily to fill the gap in the sources on sugar and coffee production in Liberia. Given the scantiness of archival and secondary accounts on commercial agriculture in Liberia, I use several core texts on the cultivation of sugar cane and coffee from other parts of the world as supplementary texts. For example, the Liberian record on the prices of sugar cane mills and the boilers are incomplete. J. C. Sitterson's research (cited previously) on sugar manufacturing in the United States (17531950) helped to resolve that problem and other issues pertaining to sugar manufacturing. Mark Pendergrast's and V. D. Wickizer's studies on coffee production are essential because they include information on the technological gap that existed between Liberian coffee planters and their counterparts in Latin America. ${ }^{35}$ Richard Dunn's book on plantation agriculture in the West Indies from 1624 to 1713 provides an important background information (e.g., tools, output and technology) on sugar cane cultivation. ${ }^{36}$ Herbert Klein's "African Slavery in Latin America and the Caribbean," serves as an introductory work on the production of the staples. ${ }^{37}$ Klein's book highlights the history of sugar cane and coffee cultivation and the critical role of labor and technology in the industry.

\footnotetext{
${ }^{35}$ Mark Pendergrast, Uncommon Grounds: The History of Coffee and How it Transformed Our World (New York: Basic Books, 1999); V. D. Wickizer, The World Coffee Economy: With Special reference to Control Schemes (Stanford: Stanford University, 1949).

${ }^{36}$ Richard Dunn, Sugar and Slaves: The Rise of the Planter Class in the English West Indies, 1624-1713 (New York: W. W. Norton \& Co., 1973), 272.

${ }^{37}$ Herbert S. Klein, African Slavery in Latin America and the Caribbean (New York: Oxford University Press, 1986).
} 


\section{Liberian Agriculture}

In this final category, the work of Akpan, Liebenow, Sawyer and Brown represent the dominant view on the history of agriculture in the historiography. (All are previously cited.) These authors identified obstacles (e.g., the lack of cap0ital) that hindered the development of plantation agriculture. However, they invariably contend that it was the Americo-Liberians' disdain for agricultural labor that ultimately prevented them from succeeding as planters. Amos Sawyer's book contains more detailed information and analysis on the Americo-Liberians' attitude toward agriculture. He notes that the contempt for agriculture was more evident among the educated upper class of AmericoLiberians. From this class emerged the prosperous "merchant princes" and officials of the Liberian government. He praises the lower classes, the "rural planters" for the efforts in producing sugar and coffee for the overseas trade, in spite of the difficulty they encountered. Sawyer asserts that the rural farmers "came closer to the ideas of Jeffersonian agrarianism." In the end, however, Sawyer like the other scholars, attributes the poor state of commercial agriculture to the negligence of the settlers. ${ }^{38}$ I will examine the alleged motives for the neglect of agriculture in the next section, under the caption, "The Motives for the Neglect of Agriculture."

A few authors hold an opinion that is somewhat different from the conventional interpretation that the Americo-Liberian shunned agriculture. For example, another study by Tom Shick, which concentrates on immigration and the formation of the Liberian state, emphasizes that important progress was made in sugar cane and coffee production.

\footnotetext{
${ }^{38}$ Sawyer, The Emergence of Autocracy in Liberia, 105, 114, 163-164.
} 
He attributes the poor state of agriculture mainly to the inability of the ACS and the United States to provide the settlers with the necessary resources for developing agriculture. ${ }^{39}$ For his part, Santosh Saha directly challenges the standard interpretation that the Americo-Liberians neglected agriculture. As proof, he argues that the immigrants adopted agricultural values (e.g., record-keeping, surveying, fencing, annual agricultural fairs) from the United States. Moreover, Saha argues, that the production of sugar and coffee during the second half of the century, contradicts the assumption that the immigrants neglected commercial agriculture. ${ }^{40}$

Saha's work has not received the attention that it deserves, given the controversial nature of his thesis. Those who have read his book dismiss it, stating that Saha's methodology is superficial and substandard. ${ }^{41}$ One critic responded to Saha's theory by pointing out that the adoption of American values is not necessarily sufficient proof that the Americo-Liberians did not neglect agriculture. ${ }^{42}$ But despite the criticisms, none of the scholars rejected the main tenet of Saha's thesis: that is, since the evidence shows that the settlers cultivated sugar cane and coffee and adopted American farming values, they cannot justly be accused of negligence.

\footnotetext{
${ }^{39}$ Tom W. Shick, Behold the Promised Land: A History of Afro-American Settlement in Nineteenth-Century Liberia (Baltimore: John Hopkins University Press, 1981), esp. Chapters 8-9.

${ }^{40}$ Santosh C. Saha, A History of Agriculture in Liberia, 1822-1970: Transference of American Values (Lewiston: Edwin Mellen, 1990).

${ }^{41}$ For example, see, Cyril E. Broderick, "Liberian Agriculture: History and Status Toward the Twenty-first Century" Liberian Studies Journal, 23, 1 (1998): 45.

${ }^{42}$ Personal Communication from John Yoder, Professor of History and Political Studies, Whitworth College, Spokane, Washington, February, 2002.
} 
My work differs in several respects from studies in the current literature. Outside of Saha's work, my dissertation will be the first comprehensive history of agriculture in nineteenth-century Liberia. All the authors that hold the dominant view on agriculture set out to write a political or an economic history of Liberia. As such, agriculture is not the focus of their investigation. One drawback in these studies is that most of their conclusions are not the result of original research. Quite frequently the authors repeat the same findings found in the studies of their colleagues. ${ }^{43}$ My work is also fundamentally different from that of Shick and Saha's. Shick's book, which is mainly a history of the founding of the Americo-Liberian state, discussed sugar cane and coffee farming very briefly. It focused on the achievements made in one region. I hope to bring a much broader interpretation to the subject by covering all the principal centers of sugar cane and coffee cultivation. The major weakness in Saha's work, in my opinion, is his inability to explain the changes that occurred in the mid-century which spurred the expansion of sugar cane and coffee cultivation. I set aside one chapter for this topic.

\section{The Motives for the Neglect of Agriculture}

Scholars have outlined four reasons why the Americo-Liberians resented cultivation. The motives centered almost exclusively on the immigrants' experience with slavery in the United States. I will address them individually. The first explanation has to do with the notion that the immigrants disdained agriculture because they were accustomed to work only under the coercive system of slavery. In other words, without

\footnotetext{
${ }^{43}$ The most glaring example of this duplication is found in the reasons that the scholars gave for the neglect of agriculture. The explanations are very identical, in some cases, even verbatim. For example, see, Akpan, "The Liberian Economy," 4; Liebenow, Liberia: The Evolution of Privilege, 12-13; Sawyer The Emergence of Autocracy in Liberia, 164-165; Brown, An Economic History of Liberia, 139-140.
} 
the system of slavery in Liberia, the former slaves did not have the will to work. (See the epigraph at the beginning of chapter.) The evidence that Akpan cited to corroborate his charge that the immigrants did not want to work because they "equated their newly won freedom with abstinence from labour," is from the archives. The archival source is a communication of 1831 which was written by William Mechlin, Agent of the Colony of Liberia. Mechlin did write that the immigrants "have so long been accustomed to be forced to work, that they will not voluntarily exert themselves beyond what is absolutely necessary to procure a miserable and precarious subsistence." However, this comment was only one of several reasons that Mechlin sent to the ACS in Washington, D.C., to explain the "very imperfect state" of agriculture. ${ }^{44}$ The other reasons Mechlin gave are:

The agriculture of the Colony, although much improved, still remains in a very imperfect state; we have not as yet adopted to any extent the agricultural improvements of civilized countries, nor do I think we are sufficiently well acquainted with the proper time for planting... The crops of last year did not succeed well in consequence of the unusual drought ... The generality of the emigrants finding that they can acquire a subsistence for themselves and their families by other pursuits are very apt to consider agriculture as a secondary importance ... One of the chief obstacles ... is the mania for trading which pervades all classes. ${ }^{45}$

It is obvious from the archival evidence that Akpan omitted the larger portion of Mechlin's remarks. Furthermore, throughout the century, various administrators in Liberia gave their own assessments for the failure of agriculture. For example, in 1843 Governor Joseph J. Roberts wrote the following remarks in his report about agriculture: "As the Colony suffers much for want of capital, so the mass of the people are without adequate knowledge of the best modes of tropical agriculture; and but few are well

\footnotetext{
${ }^{41}$ The African Repository and Colonial Journal (hereafter AR \& CJ), 1831, 259-260.

${ }^{45}$ Ibid., 259.
} 
acquainted with some of the most useful arts." ${ }^{46}$ Akpan overlooked these other causes listed in the archives for the failure of agriculture.

Another reason often presented to explain why the immigrants supposedly disdained cultivation, is that agriculture evoked unpleasant memories of slavery. ${ }^{47}$ The fact that none of the scholars documented the source of this information or elaborated on the allegation, makes it difficult to challenge. Yet, evidence from the archives and the correspondence of the immigrants suggest that this generalization is problematic. The following excerpts from the letters of former slaves attest to the problem: James P. Skipwith, ex-slave of John H. Cocke, 1859: "I am trying to Farm But cannot see But little Progress as yet;" Robert M. Page, former slave of Anne Randolph Page, 1839: "My principal business is farming and working in the black smith shop;" James McGeorge, former slave of John McDonogh, 1844: "The land up that river is very good and all it would want would be means to carry farming into operation. ...;" William C. Burke, former slave of Confederate General Robert Lee, 1854: "The only farmers here who are making anything for sale, are those who come to this country with money." 48 Accounts in the narratives and archives confirm that many of the former slaves were overjoyed and grateful to finally possessed their own land in Liberia, something they had always longed for in the United States.

\footnotetext{
${ }^{46}$ The Annual Report of the American Colonization Society, (hereafter Annual Report), 1843, 12.

${ }^{47}$ For example, see, Dwight N. Syfert, "The Liberian Coasting Trade, 1822-1900," 219; Liebenow, Liberia: The Evolution of Privilege, 12-13; Akpan, "The Liberian Economy,'4-5.

${ }^{48}$ Wiley, Slaves No More, 92, 102, 135 and 191.
} 
The third reason advanced for the failure of agriculture is that the AmericoLiberians disliked African foods and instead preferred imported American provisions (including pork, bacon, Irish potatoes and flour). ${ }^{49}$ This bias in favor of American food, Akpan claimed, was "hardly compatible with enthusiasm for agriculture." ${ }^{50}$ The archival evidence does confirm that the wealthy class imported American foodstuffs and some were probably dissatisfied with the carbohydrate-centered African diet (i.e., cassava, rice and potatoes). ${ }^{51}$ But the same sources demonstrated that some prosperous AmericoLiberians, as well as the vast majority of the poor who could not afford to buy imported food, did relish African dishes. A story found in a letter of 1859 that was written by Joseph J. Roberts, who served as President of Liberia in two different periods, is illustrative:

The natives, whose villages we traversed, were most kind and obliging.; Zodah Queah manifested his delight at our visit to his town by repeated embraces, and a bountiful supply of "dumb-bay" and "wheaney soup,"-whether of monkey, boa constrictor, or what not, no one presumed to inquire-sufficient that some of us thought we could discover traces of chicken, and set-to with a hearty good will, seeming not only to relish, but to do justice to King Zodah's hospitality. ${ }^{52}$

A second anecdote discovered in the archives presents further evidence that many of the elites learned to savor African cuisine. In 1870, during a program in Liberia to celebrate the abolition of slavery in the British West Indies a group of five AmericoLiberians traveled to one of the settlements. They lunched at the home of another

\footnotetext{
"Akpan, "The Liberian Economy," 4-5; Liebenow, Liberia: The Evolution of Privilege, 12-13.

${ }^{50}$ Ibid. 5

${ }^{51}$ The African Repository (hereafter AR), 1886, 7.

${ }^{52} \mathrm{AR}, 1859,248$.
} 
Americo-Liberian. The meal was "dumboy," probably the "dum-bay" that ex-President

Robert and his traveling companions had enjoyed. ${ }^{53}$

We had scarcely finished friendly greetings ... when another little "stir" arrested our attention, and lo, a fine Liberian "Dumboy," the very name of which is associated with so many pleasant reminiscences. Soup-plates, spoons, two large dishes of the above named article, with fat fowl soup, were placed before us. The Dumboy, notwithstanding its singular name, is a very excellent dish ... we Liberians would not exchange for any foreign dishes that could be offered. It is healthy, harmless and very nutritious. ${ }^{54}$

There are several significant points to this story. The dumboy was cooked in the home of an Americo-Liberian and eaten by very prominent Americo-Liberians. Three of the five visitors were females, who it would be safe to assume, were familiar with Liberian cuisine. The ladies were also very important members of the Liberian social elite. They were, First Lady Mrs. Roye, former First Lady Mrs. Benson, and Mrs. Blyden, "consort" of Professor Edward Blyden. One of the men was a professor at Liberia College and the other, the Commissioner of Education. The Commissioner, Rev. G. W. Gibson, became President of Liberia in 1902.

Accounts of the foods consumed by the poorer immigrants confirmed that they could not afford the prices of imported foods. William Burke, the emancipated slave of Robert Lee, wrote: "We have a vegetable known by the name eddoe, or tania, very much like our Irish potato, a very excellent breadstuff. I raised a quantity of them, which my

\footnotetext{
${ }^{53}$ An explanation for the origin of the word dumboy is found in AR, 1866, 280. According to the African Repository, dumboy is derived from the Bassa language, which is the corrupted form of the word "dor" meaning cassava and "bouy" mortar. Together the word "dorbouy" denotes the cooked cassava that is prepared by pounding in a mortar. Therefore, according to the article, the proper form of the word is "Dorbouy." The Dorbouy is "eaten" (more precisely swallowed) by dousing the dough in a spicy soup (usually made with a combination of fish, meat or chicken) and cutting it into small pieces. The pieces are then swallowed. Dorbouy (commonly called Dumboy) is still one of the principal dishes in Liberia. It is eaten by all the sixteen ethnic groups and the Americo-Liberians.

${ }^{54}$ The Liberian Register, (n.d.), quoted in AR, 1870, 311-314.
} 
family live upon, they being very wholesome."55 Another immigrant, Henry Hannon, wrote his former master (sometime in the 1840s) and included the following:

You desire of me to mention something about meat and Bread stuffs that we have in Africa. When we want Bread we take the Rice, beat it in a morter, siften it until it become a beautiful white flour, knead it \& Break it as other Bread. Meats, we have a great meny wild Deer, hogs, goats, and meny other animals. Very good meats when we can get them we cannot get Every time we want them. ${ }^{56}$

Finally, in 1870 a dozen newcomers informed acquaintances in the United States:

"We have under cultivation, rice, peas, potatoes, corn, eddoes, cassadas, ginger, figs, and arrow root. Every family is well satisfied."57 These stories strongly suggest that the assumption that Americo-Liberians disliked African food is based on a generalization, which the facts show, did not apply to all of the immigrants.

Even the preference for American food by the Liberian immigrants, if that were consistently the case, is not sufficient evidence that they spurned agriculture. The food habits of British settlers in the West Indies corroborate this point. According to historian Richard Dunn, many of the planters "imported most of their food from England, Ireland and North America."58 Their bias in favor of European diet did not prevent some of them from becoming wealthy sugar planters. A study by the anthropologist Sidney Mintz on Caribbean slaves may help to better explain the Liberian immigrants' attachment to American food-if this was indeed the case. According to Mintz, freedom meant many

\footnotetext{
${ }^{55}$ Wiley, Slaves No More, 206.

${ }^{56}$ W. Wayne Smith, ed. "A Marylander in Africa: The Letters of Henry Hannon," Maryland Historical Magazine 69, 4 (1974), 403.

${ }^{57} \mathrm{AR}, 1870,253$.

${ }^{58}$ Dunn, Sugar and Slaves, 272.
} 
different things for former slaves. They were obviously happy that freedom meant the end of the drudgery and brutality that they had to endure daily. More significantly (at least for this study) Mintz discovered that freedom for the former bondspeople meant that for the first time they had the opportunity to choose their own "food." ${ }^{59}$ A little over a century before Mintz conducted his study, Booker T. Washington, the former American slave, who became one of the prominent black leaders in the last two centuries, expressed the same feelings in his autobiography: "I remember that at one time I saw two of my young mistresses and some lady visitors eating ginger-cakes in the yard ... and I then and there resolved that, if I ever got free, the height of my ambition would be reached if I could . . . eat ginger-cakes in the way I saw those ladies doing." 60

The last explanation given for the neglect of agriculture suggests that prolonged residency in the United States may have had a greater impact on the mulatto segment of the Americo-Liberian community. According to Akpan, the mulattoes, who made up a smaller percentage of the total population, contended that they were more susceptible to malaria than the darker-skinned settlers. They further asserted that the strenuous agricultural labor exposed them to the deadly malarial infection. For this reason, many of them did not engage in cultivation but rather chose careers in government and commerce. ${ }^{61}$ The question that the mulatto immigrants were more susceptibility to

\footnotetext{
${ }^{59}$ Sidney Mintz, "Tasting Food, Tasting Freedom", in Slavery in the Americas, Wolfgang Binder, ed. (Germany: Königshausen, 1993), 257.

${ }^{60}$ Booker T. Washington, Up From Slavery (1901 rpt. New York: Penguin Books, 1986), 10.

${ }^{61}$ Akpan, "The Liberian Economy," 6.
} 
malaria than the darker-skinned settlers will remain unresolved for now, mainly because the evidence is thin, inconclusive and controversial. ${ }^{62}$

In sum, the standard interpretation that the Americo-Liberians disdained agriculture because it evoked unpleasant memories of slavery is not supported by either the historical facts or the secondary accounts.

\section{Situating Liberian Agriculture in the Context of West African History}

If the facts do not support the evidence presented by scholars, how does one explain the origins of the allegation that the Americo-Liberians neglected agriculture or that they were simply lazy? Or the assumption that the preference for commerce over agriculture was an anomaly in the nineteenth century. A review of the archives and the historiography reveals that these themes dominate the history of Liberian agriculture. I believe that both topics can be better understood by an analysis of the circumstances that existed in West Africa and the Atlantic World in the nineteenth century.

\section{The Impact of Legitimate Commerce}

West Africa underwent tremendous changes in the nineteenth century. One catalyst for the change was the abolition of the transatlantic slave trade by England and the United States, followed immediately by the introduction of the concept of "Legitimate Commerce." With the abolition of the slave trade by England and the United States in

\footnotetext{
${ }^{62}$ For some perspectives on the subject, see, Edward W. Blyden, "On Mixed Races In Liberia ," in Annual Report of the Board of Regents of the Smithsonian Institute, 386-388 (Washington: Government Printing Office, 1871); Kenneth F. Kiple, Another Dimension of the Black Diaspora: Diet, Disease, and Racism (New York: Cambridge University press, 1981), esp. 53, 56 and 62; J. B. Webster and A. A. Boahen, History of West Africa: The Revolutionary Years-1815 to Independence (New York: Praeger Publishers, 1970), 154.
} 
1807 and 1808 respectively, abolitionists proposed that African societies cultivate primary staples that were needed in Europe and the United States. The staples included palm oil, groundnuts, coffee and sugar. In exchange for their agricultural commodities, African cultivators would receive Western manufactured goods such as textiles, spirits, salt, and iron. ${ }^{63}$ This new trade arrangement was called Legitimate Commerce to distinguish it from the traffic in slaves that England and the United States had declared illegal. $^{64}$

West Africa responded favorably to the new concept, in spite of the fact that slave ships continued to purchase captives from ports along the coast. ${ }^{65}$ In the Senegambia region (roughly present-day Senegal and the Gambia), the French Government opened agricultural experimental stations for the promotion of cotton, tobacco, coffee and sugar cane. ${ }^{66}$ The project floundered and was finally abandoned by the $1870 \mathrm{~s}^{67}$ Labor shortage was one of the reasons given for the failure. ${ }^{68}$ Peanuts or groundnuts, which were first

\footnotetext{
${ }^{63}$ Anthony Hopkins, An Economic History of West Africa (New York: Columbia University Press, 1973), 125-135. The literature here is vast. See, for example, Robin Law, ed. From Slave Trade to 'legitimate' Commerce: The commercial Transition in Nineteenth-century West Africa (New York: Cambridge University Press, 1995); J. F. Ade Ajayi and Michael Crowder, History of West Africa vol. 2, (New York: Columbia University Press, 1973).

${ }^{64}$ One of the foremost proponents of legitimate commerce was the English abolitionist, Thomas Fowell Buxton. His ideas on the subject are contained in the following text. Thomas Fowell Buxton, The African Slave Trade and its Remedy (London: Dawsons of Pall Mal, 1968), Chapter II. A summary of the application of Legitimate Commerce in Africa is discussed by J. B. Webster. J. B. Webster, "The Bible and the Plough," Journal of Historical Society of Nigeria African 2, 4 (1963): 418-434.

${ }^{65}$ Ajayi and Crowder, History of West Africa vol. 2, 43-47.

${ }^{66}$ Boubacar Barry, Senegambia and the Atlantic Slave Trade (New York: Cambridge University Press, 1998), 137-139; A. G. Hopkins, An Economy History of West Africa (New York: Columbia University Press, 1973), 137-138.

${ }^{67}$ Hopkins, An Economic History of West Africa, 137-138; Barry, Senegambia and the Atlantic Slave Trade, 137-139.

${ }^{68}$ Ibid.
} 
cultivated by Africans in the Senegambia in the 1830 s, became the most successful agricultural crop of the region. ${ }^{69}$ From the 1840 s, peanuts were exported from the region. In France, the grease extracted from the peanut was converted to lubricants and cooking oil. $^{70}$

The failure of plantation agriculture in the Senegambia combined with the expansion of industrialization in Europe, led to renewed interest in some of the non-slave commodities that were exported during the slave trade. Gum, leather, beeswax and ivory were among the leading old trade goods from the region. ${ }^{71}$ Gum was a valuable ingredient in the manufacture of textile, while beeswax was used in the medical industry. ${ }^{72}$ Gum and beeswax were collected, although the former was later grown with considerable success. ${ }^{73}$ The bulk of these old trade goods was procured from the interior. $^{74}$

Further south in the British Colony of Sierra Leone, the cultivation of agricultural staples for legitimate commerce was also unsuccessful. Freetown, the original settlement, was established by English philanthropists in 1787 as a refuge for indigent Africans from London. Gradually, African immigrants from Nova Scotia in Canada and Jamaica joined

${ }^{69}$ Barry, Senegambia and the Atlantic Slave Trade, 142-145; Hopkins, An Economic History of West Africa, 141; George E. Brooks, "Peanuts and Colonialism: Consequences of the Commercialization of Peanuts in West Africa, 1830-70," Journal of African History XVI, 1 (1975): 29-54.

${ }^{70}$ Ibid.; See also Law, From Slaves to 'legitimate' commerce.

${ }^{71}$ Barry, Senegambia and the Atlantic Slave Trade, 129-147; Hopkins, An Economic History of West Africa, Chapter 4.

${ }^{72}$ Barry, Senegambia and the Slave Trade, 69; Hopkins, An Economic History of West Africa, 88; Ajayi and Crowder, History of West Africa, 46.

${ }^{73}$ Barry, Senegambia and the Slave Trade, 69-86, 140; Ajayi and Crowder, History of West Africa, 344.

${ }^{74}$ Ibid., 146; Ibid., 352-353. 
the London settlers in Freetown. The last group of settlers were the Recaptives, liberated from slave ships on the Atlantic Ocean. ${ }^{75}$ Outside of the small quantities of peanuts that were cultivated by the immigrants, hardly any other staple was grown in the colony. British colonial officials in Sierra Leone usually lay the blame for the lack of agricultural crops in the colony on the African immigrants, who they characterized as lazy. ${ }^{76} \mathrm{~A}$ number of historians such as, Christopher Fyfe, J. F. Ade Ajayi and Michael Crowder have presented an alternative explanation. They ascribed the failure of agriculture, not to indolence, but to poor soil..$^{77}$

Timber was probably the primary export of Sierra Leone for most of the first half of the $1800 \mathrm{~s} .{ }^{78}$ Africans felled the trees and prepared them for shipment to Britain where they were used for building ships. ${ }^{79}$ By the end of the 1860 s, the timber trade had come to an end because the primary forest trees along the coast of Freetown were nearly depleted. Moreover, the change from timber to iron for shipbuilding may have delivered the deathblow to the industry. ${ }^{80}$

The other commodities from Sierra Leone that formed part of the legitimate commerce of the era were gold, palm oil and palm kernels. ${ }^{81}$ Palm oil and palm kernels

\footnotetext{
${ }^{75}$ Ibid., 35-52.

${ }^{76}$ Christopher Fyfe, A History of Sierra Leone (Oxford, UK: Oxford University Press, 1962), 259.

${ }^{77}$ Ajayi and Crowder, History of West Africa, 39.

${ }^{78}$ Ibid., 46; Hopkins, An Economic History of West Africa, 138.

${ }^{79}$ Ajayi and Crowder, History of West Africa, 46.

${ }^{80}$ Ibid.

${ }^{81}$ Hopkins, An Economic History of West Africa, 138.
} 
were used in industrial Europe essentially for the manufacture of lubricants, soaps, candles and margarine. ${ }^{82}$ For the most part, the immigrant community of Sierra Leone (especially the Creoles) served as distributors of European manufactured goods. They exchanged their wares with the people of the interior for gold and other products which were sold to foreign merchants on the coast for more manufactured goods. ${ }^{83}$

In the Americo-Liberian colony of Liberia, east of Sierra Leone, officials of the ACS viewed the production of staples as a disappointment. Sugar cane and coffee were the only two commodities that were grown with any degree of success. In addition to sugar and coffee, palm oil and camwood (used primarily as lubricant and for dyeing textile respectively) were exported. The Americo-Liberians obtained the palm oil and the camwood from the indigenous people. While some officials in the ACS considered the lack of capital and equipment to be the main obstacles to the cultivation of agricultural staples, others charged that the Americo-Liberians were lazy. As proof, the officials pointed out that the immigrants preferred commerce to agricultural labor. ${ }^{84}$

In the region east of Liberia, advancement in commercial agriculture was largely limited to palm oil production. For instance, in the Niger Delta, palm oil cultivation was very successful. Outside of palm oil production, however, hardly any other staple crops

\footnotetext{
${ }^{75}$ The account of the palm oil and palm kernel trade can be found in most history books on West Africa. So far, a 1997 publication by Martin Lynn offers the most illuminating details. Martin Lynn, Commerce and Economic Change in West Africa: The Palm Oil Trade in the Nineteenth Century (UK: Cambridge University Press, 1997).

${ }^{83}$ Ibid. 47-53; Hopkins, An Economic History of West Africa, 152-154. For a detailed account of the commercial activity of the Creoles in West Africa, see, Akintola Wyse, The Krio of Sierra Leone: An Interpretive History (London: C. Hurst and Co., 1989).

${ }^{84}$ See, Annual Report. 1856, 30; AR \& CJ. 1831, 259-260.
} 
were cultivated for sale overseas. ${ }^{85}$ The Danes did succeed for sometime in establishing plantations in the south-east region of the Gold Coast from the late eighteenth to the midnineteenth century. Some staples such as cotton and maize were exported. Overall, the Gold Coast plantations did not live up to the high expectation of the Danes. The plantations were eventually abandoned. ${ }^{86}$ In Abeokuta, in south-east Nigeria, the English succeeded in growing cotton but production declined in the 1870 s, reportedly in part, to the "high cost of free African labour." ${ }^{, 77}$ During the 1880s, African farmers in the Gold Coast and southern Nigeria made remarkable progress in agriculture when they began to cultivate cocoa ${ }^{88}$ Cocoa would become a leading source of foreign exchange for the Gold Coast in the twentieth century.

The following conclusion can be drawn from the brief account of economic activities on the West Coast of Africa in the nineteenth century. First, the goal of the abolitionists, to turn West Africans into cultivators of primary staples for export to the West, was partly successful. Peanuts from the Senegambia, palm oil and palm kernels largely from the Bights of Benin and Biafra were the obvious accomplishments. But attempts to cultivate the other staples (e.g., coffee and cotton) ultimately faltered.

Second, a majority of the commodities that West Africa sold abroad during the nineteenth century were collected or produced in the interior. The coastal societies played the role of

\footnotetext{
${ }^{85}$ For details on the palm oil trade, see, Martin Lynn, Commerce and Economic Change in West Africa and Hopkins, An Economic History of West Africa.

${ }^{86}$ Ray A. Kea, "Plantations and Labour in the south-east Gold Coast," in From Slave Trade to 'legitimate' commerce, ed., Law, 119-143.

${ }^{87}$ Hopkins, An Economic History of West Africa, 137-138.

${ }^{88}$ Ibid., 138.
} 
intermediaries; seldom were they producers. Finally, trade rather than the cultivation of agricultural staples, was the dominant economic enterprise on the coast of West Africa in the nineteenth century.

When viewed from this historical context, the Americo-Liberians overwhelming preference for trade over agriculture (if indeed this is correct) was not an aberration. The bias in favor of commerce appears to have been the norm for communities on the West Coast of Africa in the nineteenth century. Like the rest of the Atlantic communities on West Coast of Africa, the Americo-Liberians served as middlemen in the transatlantic trade. After agriculture, trade was the next tandem of Legitimate Commerce. From this perspective, the Americo-Liberians were fulfilling one of the goals of the new trade that was introduced in the nineteenth century. Consequently, their engagement in the transatlantic commerce was normal. Christopher Fyfe, writing in defense of the African immigrants in Sierra Leone who chose to trade instead of tilling the unproductive land, asserted that the Africans "were choosing the only occupation which paid them-and in so doing, following European example." ${ }^{199}$

\section{Probable Origins of the Assumption that Agriculture was Neglected}

The origins of the notion that the Americo-Liberians detested agricultural labor or that they "erroneously equated their newly won freedom with abstinence from labor," may be traced more closely to the transatlantic slave trade. Contemporary studies suggest that Europeans' attitude toward Africans prior to the advent of the slave trade in the $16^{\text {th }}$ century and probably throughout most of the next, was clearly different from the vicious

\footnotetext{
${ }^{89}$ Fyfe, A History of Sierra Leone, 259.
} 
notion of African inferiority so prominent in the literature of the latter period. In their examination of English narratives from the early 1700s, Dorothy Hammond and Alta Jablow, discovered that although English writers described Africans as "people of beastly living," European traders on the coast of Africa generally held a favorable impression of their African counterparts. ${ }^{90}$ Philip Curtin observed that European travelers in West Africa in the late 1700s "often condemned individual Africans as bad men-or all Africans as savage men—but they left the clear impression that Africans were men."91 And Basil Davidson wrote that the chronicles of this early period "speak often of difference; they do not speak of inferiority., 92

The notion that Africans were inferior began to creep in the English literature from about the mid-1700s. This period, historians have noted, coincided with the expansion of the Atlantic slave trade and marked the beginning of the virulent racism that Africans were to endure for the next two centuries. ${ }^{93}$ These remarks made by Thomas Jefferson in 1781 (Jefferson became President of the United States ten years later) embodied the emergent racism: "I advanced it . . . as a suspicion only, that the blacks,

\footnotetext{
${ }^{85}$ Dorothy Hammond \& Alta Jablow, The Myth of Africa (New York: The Library of Social Science, 1977), 19-20;

${ }^{91}$ Philip Curtin, The Image of Africa: British Ideas and Action, 1870-1850 (Madison: The University of Wisconsin Press, 1964), 35.

${ }^{92}$ Basil Davidson, The Search for Africa: History, Culture, Politics (New York: Random House, 1994), 43.

${ }^{93}$ Ibid., 57; Hammond \& Jablow, The Myth of Africa, 22-47; Curtin, The Image of Africa, 363-

387.Winthrop D. Jordan, The White Man's Burden: Historical Origins of Racism in the United States (New York: Oxford University Press, 1974), 26-86; George M. Fredrickson, The Arrogance of Race: Historical Perspectives on Slavery, Racism and Social Inequality (Middletown, CT: Wesleyan University Press, 1988), 189-215.
} 
whether originally a distinct race, or made distinct by time and circumstances, are inferior to whites in the endowments of both body and mind." 94

In the nineteenth century, a growing body of knowledge materialized purporting that Africans were inferior to whites in "mind and body." 95 In the southern region of the United States where Africans were subject to the indignity of involuntary servitude, the notion of the servile African was reinforced by what social scientists have referred to as a racial stereotype. The stereotype, called Sambo, was that of the African slave, "docile, but irresponsible, loyal but lazy ... utter dependence and childlike attachment" to his owner. ${ }^{96}$

The charge of the lazy and improvident African slave was made much more forcefully as the opposition to slavery gained momentum in the United States in the early decades of the 1800s. Opponents of abolition contended that if emancipated, the free African would be incapable of supporting him or herself. As a result, the apologists argued, the manumitted slaves were likely to resort to the commission of crimes in order to survive. ${ }^{97}$

\footnotetext{
${ }^{94}$ Thomas Jefferson, Notes on the State of Virginia, ed. David Waldstreicher, (1787 rpt. Bedford, MA: ST. Martin's, 2002), 180.

${ }^{95}$ A summary of the literature is found in Hammond \& Jablow, The Myth of Africa; Curtin, The Image of Africa; Davidson, The Search for Africa.

${ }^{96}$ Stanley Elkins, Slavery: A Problem in American Institutional and Intellectual Life (Chicago: University of Chicago Press, 1969), 82. See also, Fredrickson, The Arrogance of Race, 206-215 and Eugene Genovese, Roll Jordan Roll: The World the Slaves Made (New York: Vantage Books, 1974), 285-309

${ }^{97}$ Staudenraus, The African Colonization Movement, 29; Lamont D. Thomas, Paul Cuffe: Black Entrepreneur and Pan-Africanist (Urbana and Chicago: University of Illinois Press, 1988), 111; Richard West, Back to Africa: A History of Sierra Leone and Liberia (London: Jonathan Cape, 1970), 99.
} 
In Africa and the West Indies, Africans were also accused of being slothful. Historian Frederick Cooper discovered that British abolitionists and missionaries believed that former plantation slaves in Zanzibar and coastal Kenya were "without selfreliance"98 The British were convinced that only by supervision could the emancipated Africans' "deep-rooted slave instinct to be idle and thriftless" be eliminated. ${ }^{99}$ This accusation by the English is identical to the one made by William Mechlin, the white American Agent of the ACS in Liberia in 1831 (previously cited): The immigrants "have so long been accustomed to be forced to work, that they will not voluntarily exert themselves...." Both statements seem equally indistinguishable from those found in the Liberian historiography-e.g., "erroneously equated their newly won freedom with abstinence from work."

Frederick Cooper further noted that similar charges of indolence were levied against former slaves in the West Indies. According to the author, a large number of the middle-class in the West Indies, influenced by "class relations in England and experience in the West Indies" after the 1840s, considered "ex-slaves as incapable even of being a proper working class." Cooper attributes the prejudice to the "increasingly racist tenor" of the era which regarded all former slaves as inferior. ${ }^{100}$

Cooper and some others have suggested that in addition to racist motives, the influential white class believed that slaves and former slaves were indolent because the

\footnotetext{
${ }^{98}$ Frederick Cooper, From Slaves to Squatters: Plantation Labor and Agriculture in Zanzibar and Coastal Kenya, 1890-1925 (Portsmouth, N H: Heinemann 1997), 38, 45.

${ }^{99}$ Ibid.

${ }^{100}$ Ibid., 30.
} 
Africans were unaccustomed to the basic tenets of the capitalist mode of production. Some of the capitalistic principles are the regulation of work schedule and punctuality. ${ }^{101}$ Eugene Genovese recorded some complaints that slave masters made about what they described as poor work habits of the slaves. For example, most slaves were accused of opposing "regular work" or "to work half a day and then relax." 102 Another deviation from the capitalist mode of production involved the determination of emancipated slaves to freely choose where they worked and what kinds of jobs they performed. Thomas Holt and Walter Rodney documented how newly emancipated slaves in the West Indies constantly resisted attempts by the ruling class to legally bind them to plantations as wage earners. ${ }^{103}$ Similarly, after the Emancipation in the United States, the former slaves were determined to freely choose how they would allocate their time as freed men and freed women. A huge number of the freedmen and their families migrated to industrious cities in the North in search of jobs, refusing to work for wages on plantations. Those who remained in the South preferred to acquire their own farmland rather than continue to toil on the plantations, even though the Union Government assured them that they would be paid this time around. ${ }^{104}$ Quite often, the dominant white power structure would interpret such "deviant" attitudes or any other deviation from the capitalist work ethos as idleness.

${ }^{101}$ Cooper, From Slaves to Squatters, Chapters Two and Three; Eugene Genovese, Roll Jordan Roll: The World the Slaves Made (New York: Vantage Books, 1974), 285-309.

${ }^{102}$ Genovese, Roll Jordan Roll: The World the Slaves Made, 300-301.

${ }^{103}$ Thomas C. Holt, The Problem of Freedom: Race, Labor, and Politics in Jamaica and Britain, 18321938 (Baltimore: John Hopkins University Press, 1992), esp., 13-79; Walter Rodney, A History of the Guyanese Working People, 1881-1905 (Baltimore: John Hopkins University Press, 1981), 120-173.

${ }^{104}$ Edward Madgol. A Right to Land: Essays on the Freedmen's Community (Westport, CT: Greenwood Press, 1977). 
It seems quite obvious from the history of slavery that the charge of laziness was used indiscriminately to characterize all African slaves and former slaves, not just the exslaves in Liberia. From all indications, it appears that the allegation of the indolent Americo-Liberian was a transatlantic stereotype deeply rooted in Euro-American racism. When the ACS was organized in 1816, some of its members explicitly stated that the goal of the new organization was to remove the free blacks, "the greatest sources of insecurity, and also of unprofitableness." ${ }^{105}$ Thus the idea of the lazy and slothful Americo-Liberian, who was not used to working unsupervised, predated the founding of Liberia. The historical facts certainly weighed heavily in favor of Frederick Cooper's conclusion on the subject: "Being an ex-slave, being black, being lazy, and causing disorder became increasingly linked." 106

I conclude this chapter by re-emphasizing the need for writing an alternative history of commercial agriculture for nineteenth-century Liberia. In the preceding discussion, I demonstrated that the conventional explanation for the alleged failure of commercial agriculture is suspect. Too often, accounts in the current historiography were contradicted by the facts in the archives and the secondary sources. An example of the inconsistency is found in the explanations scholars have advanced for the alleged neglect of agriculture. Hardly any proof was found to support the popular assumption that the Americo-Liberians disdained commercial agriculture because they associated farming in Liberia with the unpleasant memories of slavery in the United States. The very fact that they produced sugar and coffee in the first place is sufficient reason to raise doubts about

\footnotetext{
${ }^{105}$ Staudenraus, The African Colonization Movement, 29.

${ }^{106}$ Cooper, From Slaves to Squatters, 30.
} 
the notion that cultivation reminded the Americo-Liberians of involuntary servitude.

Because of these, and other questionable assumptions in the current literature, there is a need to reconstruct a new interpretation of the history of commercial agriculture in nineteenth-century Liberia.

This dissertation is organized into seven chapters. The research objective, the sources and methodology, the literature review and a brief discussion on the socioeconomic environment of the Atlantic World in the nineteenth century are presented in Chapter I. Chapter II includes the historical overview of the founding of Liberia, the agricultural ecology and the expansion of agriculture. The history of sugar cane and coffee farming is presented in Chapters III and IV. In Chapter V, the impact of environmental and demographic constraints on agriculture are considered. Chapter VI explains the causes for the decline Liberia's overseas trade. Chapter VII, the final section, summarizes the central thesis in the dissertation. 


\section{CHAPTER II}

\section{AMERICO-LIBERIAN SETTLEMENT AND AGRICULTURAL ECOLOGY}

$1822-1850$

The interest now manifested by the farmers, I think, has never been surpassed. The success that attended the sugar operations at the colonial farm, the M. E. mission farm at White Plains, and Mr. Willis's farm at Millsburg, have convinced the people pretty generally of the practicability of farming.

—Joseph J. Roberts ${ }^{1}$

\section{Establishment of the Liberian Settlement}

\section{Formation of the American Colonization Society}

The idea of repatriating free blacks to Africa began to gain momentum in the United States during the last quarter of the eighteenth century. It was prompted by concern over the growing number of free blacks in the United States. Some Americans considered the large population of free blacks a national threat and therefore, wanted to send them away. For others, the presence of a burgeoning population of free blacks in American society was a sad reminder of the inhumane system of slavery and social injustice. The solution to the problem of suffering and discrimination, the humanitarians believed, was to repatriate the afflicted population to Africa. Thus, trepidation and empathy became the driving force behind the African colonization movement and the founding of Liberia.

Indeed, the population of free blacks did increase markedly in the United States between the 1790s and the next four decades or so. Two factors that contributed to the

${ }^{A R} \&$ CJ, 181843, 16. 
growth were the evolution of the anti-slavery movement in the North and the impact of the American war of independence. The anti-slavery crusade commenced in the $1760 \mathrm{~s}$ when the Christian religious sect called the Society of Friends or Quakers began to publicly speak out against the evils of slavery. ${ }^{2}$ By the end of the century, several Christian denominations had joined the anti-slavery crusade. The success of the abolition movement became evident by the close of the eighteenth century, when several northern states either declared slavery illegal or enacted laws that allowed for gradual emancipation. Vermont led the way by abolishing slavery in 1777 , followed by Massachusetts and Pennsylvania in the 1780s. Finally, Rhode Island and Connecticut enacted laws for gradual emancipation in 1784 and in 1799, New York did likewise. ${ }^{3}$ So successful was the abolition movement that by the end of the 1820 s, all the northern states had declared slavery illegal and emancipated the slaves. As a result of this action, the population of free blacks expanded.

A large number of the free blacks had also become free during the War of Independence (1776-1783). Some slaves took the opportunity presented by the chaos and simply fled from their masters. Many others received their freedom as a reward for serving in the war on the side of the victorious thirteen states. Still, many more slaves

\footnotetext{
${ }^{2}$ See, Gary B. Nash and Jean R. Soderlund, Freedom by Degrees: Emancipation in Pennsylvania and its Aftermath (New York: Oxford University Press, 1991), esp. chap.3; Hiram H. Hilty, Toward Freedom For All: North Carolina Quakers and Slavery (Richmond, IN.: Friends United Press, 1984), 13-43.

${ }^{3}$ Nash and Soderlund, Freedom by Degrees, chap. 3; Mary Berth Norton et al., A People and a Nation: A History of the United States (Boston: Houghton Mifflin Co, 2002), 124-126; Paul S. Boyer et al., The Enduring Vision: A History of the American People (Boston: Houghton Mifflin Co, 2002). 123-124.
} 
were manumitted by their masters who were motivated by the same enlightened principles of freedom and equality that had inspired them to rise up against British rule. ${ }^{4}$

The abolition of slavery in the North and the manumission of slaves as a consequence of the war gave rise to an increasing population of free blacks. For instance, the total number of free blacks in the United States in 1790 was about 60,000 , but rose to 108,000 by the early years of the 1800 s. $^{5}$ By 1810 , the total number of free blacks had risen to approximately 150,000 . It continued to increase for several more decades, although at a lower rate. ${ }^{6}$ It was such staggering growth that inspired both the sympathy and the fear that set the plan for colonization in motion.

Among the earliest proponents of African colonization in the United States were the Calvinists, a religious sect from the Protestant Reformation era of sixteenth-century Europe. A cardinal principle of the American Calvinists was the belief that they had a moral obligation to help alleviate the suffering of all, "pagans and heathen, the urban and rural poor, the oppressed, the drunk, the destitute, and all sorts and conditions of humanity." Motivated by this sense of conscientious obligation, Calvinists were appalled by the level of social ills in American society. They viewed the miserable and wretched life of free blacks in the United States with dismal. Moreover, the Calvinists were convinced that given the level of racism and prejudice in the United States, white

\footnotetext{
${ }^{4}$ Ibid.

${ }^{5}$ Ibid.

${ }^{6}$ John Hope Franklin, From Slavery to Freedom: History of American Negroes (New York: Alfred A. Knopf, 194), 214-215; Paul S. Boyer et al., The Enduring Vision, 124.

${ }^{7}$ Sawyer, The Emergence of Autocracy, 17.
} 
America would never treat the free blacks as equals. Thus, they regarded the colonization of free blacks in Africa as the best solution to the "Negro" problem. In Africa, the Calvinists believed that the repatriates would have the opportunity to enjoy freedom and at the same time, attain social and economic development.

Some Calvinists envisioned the repatriates as missionaries, spreading the Gospel to "pagans and infidels" in Africa. ${ }^{8}$ Reverend Samuel Hopkins of Rhode Island was one such Calvinist. In the early 1770s, Hopkins began training a number of free blacks for evangelical service in Africa. He enrolled two of the prospective missionaries in theological classes at Princeton College, but his colonization plan was disrupted by the war of independence. ${ }^{9}$ Another clergy from the North called Reverend Robert Finley, who was also distressed by the dismal conditions of free blacks in his native New Jersey, later outlined a plan for colonizing free blacks that was similar to that of Hopkins'.

On the side of those who supported colonization out of the alarm presented by the large number of free blacks were some of the leading political figures of the era. Thomas Jefferson, the man who had written the memorable clause, "All men are created equal," offered a dire prediction about the danger posed by the burgeoning population of blacks: "Deep-rooted prejudices entertained by the whites; ten thousand recollections by the blacks ... will divide us ... and produce convulsions which will probably never end but in the extermination of the one or the other race." Jefferson warned that "a revolution of the wheel of fortune" might place the slave over his master. ${ }^{10}$ To prevent this catastrophe,

\footnotetext{
${ }^{8}$ Staudenraus, 4-5.

${ }^{9}$ Ibid.

${ }^{10}$ Thomas Jefferson, Notes on the State of Virginia, 175-176, 196.
} 
Jefferson formulated his own colonization plan. It called for the gradual emancipation of slaves, to be followed immediately by removal from the United States. ${ }^{11}$

Indeed, Jefferson's apocalypse did come to pass-albeit outside of the United States. In 1791, few years after his prophecy, the most violent slave revolt in the New World occurred on the French sugar colony of San Domingo (present-day Haiti). The revolt was led by an ex-slave called Toussaint Louverture. A large number of white slave masters, as well as blacks, lost their lives in the dozen or so years of fighting. In the end, the Haitian sugar industry, the largest producer in the world, was completely destroyed and the first government of black leaders in the New World was established in an independent Haiti. ${ }^{12}$

The slave holding class in the United States, and many of its sympathizers, saw the Haitian revolt as an ominous sign. Colonization was particularly appealing because it would rid the United States of the swelling number of free blacks whom slave masters perceived as the instigators of rebellions. Slave holders also charged that free blacks had a "mischievous influence on the slaves," because they refused to work and were predisposed to commit crimes. ${ }^{13}$ On December 28, 1816, a group of men assembled in Washington, D.C. to formally organize a body to execute the plan of colonization. The American Colonization Society was founded on that day.

\footnotetext{
Tibid., 175-176.

${ }^{12}$ For details on the Haitian Revolt, see, C. L. R. James, The Black Jacobins: Toussaint Louverture and the San Domingo Revolution (New York: The Dial Press, n.d.).

${ }^{13}$ Richard West, Back to Africa, 89-90.
} 
Most of the founding members were prominent political figures with strong ties to the slave-holding class. Henry Clay, one of the Vice Presidents of the Society, was Speaker of the House of Representatives and a slave owner from Kentucky. ${ }^{14}$ During a formative meeting, Clay allayed the fears of slave masters who were concerned that colonization might be misconstrued for abolition. He assured the slave owners that colonization was for "free Negroes," not slaves. ${ }^{15}$ John Randolph, another founding member, promised that colonization would protect slave property by removing the free blacks, the "promoters of mischief" and the "depositories of stolen goods." 16

The clergy, who all along had expressed pity for the free blacks, were also present at the meeting of 1816. Reverend Robert Finley was perhaps the leading minister in the audience with established credentials in the colonization movement. Earlier, Finley toured New York and New Jersey to raise money for his colonization plan. He had traveled to Washington and enlisted the support of prominent officials of government, including Speaker Clay and Supreme Court Justice Bushrod Washington. Francis Scott Key (author of the "Star-Spangled Banner") was another sympathizer of the free blacks at the meeting. Key, a prominent lawyer in Washington, D.C. and devout Christian, was one of those who hoped that colonization would eventually lead to the emancipation of slavery. Key had worked alongside Finley in Washington, D.C. to mobilize support for the African colonization scheme. He was elected to the Executive Board of the ACS. Robert Finley did not assume any role in the new organization, although author Lamont

\footnotetext{
T4Ibid., 96-97.

${ }^{15}$ Staudenraus, The African Colonization Movement, 28-29.

${ }^{16}$ Ibid.
} 
D. Thomas opined that the effort of the clergy was rewarded in Georgia with the

"presidency of its state university" [University of Georgia]. ${ }^{17}$

Leadership of the ACS was headed by Bushrod Washington, the president. Future United States president, General Andrew Jackson, was a member of the Executive Board. For more than two years after the formation of the society, the organization was unable to carry out its goal because it did not have the funds to implement its plan of colonization. The fortune of the organization changed in 1819 when United States President James Monroe (a sympathizer of the ACS) took advantage of a seemingly ambiguous interpretation in a Congressional Legislation and allocated some funds to the ACS. ${ }^{18} \mathrm{~A}$ year later, the organization sent the first group of emigrants to West Africa.

\section{Immigration to Liberia}

The ACS transported three major groups of immigrants to Liberia. They were the free "Negroes" from the United States, the liberated Africans or recaptured Africans and the Barbadians. Of the three groups, the emigrants from the United constituted the overwhelming majority. The largest number of free blacks was repatriated between 1822 and 1866. After 1866, fewer than 3,000 American emigrants settled in Liberia. By the

\footnotetext{
${ }^{17}$ Lamont D. Thomas, Paul Cuffe: Black Entrepreneur and Pan-Africanist (Urbana and Chicago, Il: University of Illinois Press, 1988, 115.

${ }^{18}$ The legislation was the Slave Trade Act of 1819 which authorized the President to use $\$ 100,000$ for the repatriation of Africans that the United States Navy had rescued from slave ships on the Atlantic Ocean. This law was an extension of the Act of 1808 that had abolished the slave trade in the United States. See, Staudenraus, The African Colonization Movement, 50-58.
} 
end of the century, a total of approximately 16,428 free blacks had been repatriated to Liberia. ${ }^{19}$

\section{United States Immigrants}

Between 1822 and 1866, the free blacks were recruited mainly from three regions in the United States: the South, the North and the Midwest. The southern states contributed the highest number. Virginia took the lead with 3,733 free blacks. ${ }^{20}$ Free blacks from the northern states made up the second highest total. Pennsylvania was the frontrunner, with 337 emigrants. ${ }^{21}$ The lowest regional figure consisted of 300 immigrants from seven Midwestern states. ${ }^{22}$ This pattern of regional distribution was not altered significantly after 1866 .

The free black immigrants can be classified into two major categories for the purpose of analysis. One group consisted of those that were born free, those who had purchased their freedom and anyone else who was not a slave when he or she applied to go to Liberia. In the second category were former slaves that had been emancipated by slave masters to go to Liberia. These were the emancipated immigrants. By 1866 , this group numbered slightly higher at 5,957, while the freed immigrants totaled $5,638 .^{23}$ The abolition of slavery in the United States following the end of the civil war in 1865

\footnotetext{
${ }^{19}$ Total compiled from the Annual Reports of the AC. See, Annual Report 1867; Annual Report, 1876; Annual Report, 1896. This figure corresponds, more or less, with those cited in the secondary sources.

${ }^{20} \mathrm{ACS}, 1867,64$.

${ }^{21}$ Ibid.

${ }^{22}$ Ibid.

${ }^{23}$ Ibid.
} 
rendered the distinction between both groups irrelevant, since all subsequent immigrants were legally freed by the Thirteenth Amendment. A majority of the immigrants traveled to Liberia as families. ${ }^{24}$

Even though the archival evidence is scanty and incomplete, a clear line of social distinction, based on education and occupation, can be discerned among the two groups (i.e., the emancipated and freed immigrants). Although the majority of the immigrants were illiterate, there was, however a tiny circle that had some form of literacy (i.e., the ability to read or write). This educated class was concentrated among the freed immigrants. As expected, the largest percentage of uneducated migrants was the emancipated immigrants or ex-slaves; ${ }^{25}$ southern states generally denied education to their chattels.

Occupation among the colonists can be divided into three main classes. Not surprising, the majority of the immigrants were farmers who belonged to the class of emancipated immigrants. In addition to being illiterate, these farmers usually arrived in Liberia penniless. The next occupation class consisted of a small group with some entrepreneurial background. Prior to emigration, some had operated small businesses in the United States or were earning wages. ${ }^{26}$ As a result, this tiny group of well-to-do colonists arrived in Liberia with small amounts of money or merchandise which gave

\footnotetext{
${ }^{24}$ The rolls of immigrants are listed in the most editions of the Annual Reports and the African Repository, especially from the 1850s and onward. See also, Shick, "A Quantitative Analysis of Liberian Colonization," 47; The Census and Robert Brown, Immigrants To Liberia: 1843 to 1865 (Philadelphia: Institute for Liberian Studies, 1980).

${ }^{25}$ The Census; Robert Brown, Immigrants To Liberia.

${ }^{26}$ Staudenraus, The African Colonization Movement, 154. Marie Tyler McGraw's article is interesting because it looks at one group of enterprising emigrants from Virginia. Marie Tyler McGraw, "Richmond Free Blacks and African Colonization, 1816-1832," Journal of American Studies 2, 21 (1987): 207-224.
} 
them enormous advantage over the destitute class of emancipated immigrants. They usually became successful merchants and planters.

The final occupational class was the artisans, such as blacksmiths, masons, shoemakers and leather-workers. Some were generally well off prior to emigration and continued to prosper in Liberia. Many of them experienced difficulty in Liberia either because they could not find regular employment or they did not have the raw materials required to do their jobs (e.g., leather for shoemakers). ${ }^{27}$ It should be noted in conclusion that many of the settlers could work acceptably in any of the three occupational categories, essentially being jack-of-all-trades. This was especially true for the artisans and the farmers.

\section{The Recaptured Africans or Liberated Africans}

The second largest immigrant group was the liberated Africans. They were would-be-slaves freed from slave ships on the Atlantic Ocean by United States Navy Patrol, trying to enforce the ban on the importation of slaves to the United States. There were eighteen liberated Africans in the colony. ${ }^{28}$ In 1845 , an estimated 700 recaptured Africans, the highest in the first half of the century, were resettled in Liberia. ${ }^{29}$ Between 1860 and 1861, the largest group of liberated Africans, consisting of 3,684 men, women and children, was relocated to Liberia. ${ }^{30}$ The 3,684 immigrants were probably among the

\footnotetext{
${ }^{27}$ See, Wiley, Slaves No More, 191.

${ }^{28}$ Annual Report, 1824, 161.

${ }^{29} \mathrm{AR}, 1865,149-50$.

${ }^{30}$ Ibid., 1861, 70-76.
} 
last group of liberated Africans to be resettled in Liberia. By the end of the century, a total of approximately 5,722 recaptured Africans had been transported to Liberia. Most of the would-have-been-slaves were captured in Central Africa and Nigeria. ${ }^{31}$ The majority of them claimed to have originally lived in the region of the Congo River. Therefore, the entire population of liberated Africans in Liberia became known as the "Congoes." 32

The liberated Africans were among the most destitute of the Liberian immigrants. They were mainly teenagers. Almost certainly, all of them could not read or write English. After their horrifying ordeal of captivity and experience on the slave ships, they arrived in Liberia terrified and usually completely naked. ${ }^{33}$ The rural African background of the liberated immigrants suggests that they were agriculturalists.

The Barbadians

The Barbadian emigrants, consisting of 346 men, women and children arrived in Liberia in $1865 .^{34}$ Like the emigrants from the United States, the Barbadians traveled in small family groups: 96 were children between two and twelve years old and 39 were less

\footnotetext{
${ }^{31}$ A majority of the liberated Africans claimed to have originated from "Congoes." Others were from Nigeria. AR \& CJ, 1839, 9; AR, 1859, 164; Ibid., 1860, 75. John Yoder has suggested that some of the liberated Africans from Central Africa were Luba and Lunda speakers. Others were Tiv, Ibo and Yoruba from Nigeria. Yoder's work has been submitted for publication. John Yoder, He Kill My Ma, He Kill My Pa, I Will Vote For Him: A Study of Political Culture, Civil Society and State Crisis in Liberia.

${ }^{32}$ ACS Annual Report, 1841, 23; AR \& CJ, 1847, 25; AR, 1861, 70-76.

${ }^{33} \mathrm{AR}, 1865$, 149-151; Ibid., 1863, 106-111; Ibid., 1861, 112-113, 131

${ }^{34} \mathrm{AR}, 1865,186,242$. There is a text on West Indian immigrants in West Africa in the nineteenth century. The author did not include the Barbadian-Liberians in the discussion, although the book covers the period 1808 to 1880. See Nematta Amelia Blyden, West Indians in West Africa, 1808-1880: The African Diaspora in Reverse (New York: University of Rochester Press, 2000).
} 
than two years of age. ${ }^{35}$ Barbadians had waited for several decades to emigrate to Liberia. During the visit of newly elected President Joseph J. Roberts of Liberia in 1848, members of the Barbados Colonization Society expressed the desire to emigrate and live in the land of their "forefathers." ${ }^{36}$ Because they did not have the means to cover the cost of transportation, the Barbadians had to wait until an opportunity became available. ${ }^{37}$ They got the chance in 1864. That year, the Liberian government set aside, through an act of the legislature, $\$ 4,000$ for immigration from Barbados. Besides the money, the act provided for the allocation of 25 acres of land to each Barbadian family, 15 acres more than immigrants from the United States had been allotted. ${ }^{38}$ Officials of the ACS agreed to cover the cost of transportation from Barbados to Liberia. ${ }^{39}$ The decision of the Liberian Government and the ACS was motivated largely by the decline in immigration from the United States which was exacerbated by the civil war. For instance, between 1861 and 1864 , a total of 169 immigrants was transported to Liberia, the lowest for any comparable period to that date. In 1864 (the year of the legislation was passed) only 23 immigrants were resettled in Liberia. ${ }^{40}$

\footnotetext{
${ }^{35} \mathrm{AR}, 1865,186,242$.

${ }^{36} \mathrm{AR} \& \mathrm{CJ}, 1848,240-241$.

${ }^{37}$ One Barbadian, a Mr. Tait (along with his wife and seven children) reportedly spent all his earnings to travel to Sierra Leone and then to Liberia. He hired a boat (without cover) from Sierra Leone for $\$ 1$ for the final voyage to "the promised land." Tait and his family arrived in Liberia after "nine days and nights ... wet, wearied, hungry." The Liberian Legislature made a donation of $\$ 100$ to Mr. Tait and gave him 50 acres of farmland. AR, 1865, 119-120.

${ }^{38}$ Ibid., $1865,37$.

${ }^{39}$ Ibid., 1865, 242.

${ }^{40}$ Annual Report. 1867, 56-64.
} 
The Barbadian settlers were basically an agricultural community. Just before their resettlement in Liberia, the African Repository carried an article that underscored the mutual benefits of the Barbadian emigration. For the Barbadians, it was observed that the most important gain was freedom from a life of a "kind of serf" in the Caribbean. ${ }^{41}$ In other words, for the first time, the Barbadian immigrants would have access to their own land in Liberia. Liberia, on the other hand, stood to benefit because Barbadian farmers were generally good "cultivators of the soil, ... Men familiar with the culture of the sugar-cane and the manufacture of sugar-familiar with raising arrowroot, ginger, and all of the rest of the numerous productions of the torrid zone." ${ }^{, 42}$ Of all the occupations listed for the Barbadians, agriculture or skills related to agriculture, constituted the largest category: There were planters, farmers, sugar boilers, millwrights and distillers. ${ }^{43}$ The evidence indicates that the majority of the Barbadians had some form of literacy. In 1873, the African Repository recorded: "The Barbadians are known to be the most intelligent ... There were but few of their number that could not read, write and cipher when they arrived in the country." 44

In conclusion, by the end of the century the ACS transported an estimated total of 22,496 emigrants from the United States, Nigeria and the Congo and Barbados to

\footnotetext{
AR, $1865,119$.

${ }^{42}$ Ibid.

${ }^{43}$ lbid., 236-242.

${ }^{44} \mathrm{AR}, 1873,274$.
} 
Liberia. ${ }^{45}$ In terms of occupation, agriculture was the largest class. Its members consisted of the emancipated freed immigrants from the United States, the liberated Africans and the Barbadians. These farmers were generally illiterate and impoverished. The other major professional class included the merchants and artisans. They made up a very small proportion of the immigrant population. Most of them were educated and relatively well off.

\section{$\underline{\text { Agricultural Ecology }}$}

\section{Diseases, Seasonality and Soil Quality}

The colonists from the United States were thrust into an environment that was markedly different from the temperate climate that most of them had previously inhabited. Studies in migration and disease suggest that with the exception of the liberated Africans (particularly those originally from regions with pathogens similar to the ones in Liberia), all the new immigrants were exposed to a whole new set of diseases or "virgin soil epidemics." high mortality rate of the Liberian settlers. It can be recalled that Antonio McDaniel was particularly shocked that life expectancy at birth for the immigrants was less than three

\footnotetext{
${ }^{31}$ The figure is computed from the archives. It corresponds more or less, with the number cited in secondary sources. Annual Report, 1867, 1886, 1893 and 1896. In 1897 the ACS reported that about 325 selfsponsored immigrants arrived in Liberia that year. These independent immigrants covered the cost of transportation and did not receive the six-month food ration and shelter that the ACS-sponsored immigrants were entitled to. Annual Report, 1897, 6. The total number of self-sponsored immigrants for the century is undetermined.

${ }^{46}$ The concept of "virgin soil epidemics" states that migrants or people, who have had no previous contact with a particular disease, were more likely to be susceptible to the new infection. For a summary of the theory of "virgin soil epidemics," see, Alfred W. Crosby, "Virgin Soil Epidemics as a Factor in the Aboriginal in Depopulation in America," William and Mary Quarterly 33 (1976): 293-294. The concept of "virgin soil epidemics" is discussed in details in several books. See William H. McNeill, Plagues and Peoples (New York: Anchor Books, 1998), chaps. 3, 5; Alfred W. Crosby, Ecological Imperialism: The Biological Expansion of Europe, 900-1900 (New York: Cambridge, 1986), chap. 9.
} 
years of age. A review of the census of 1843 confirms the morbidity of the Liberian environment. In spite of the fact that between 1820 and 1843 the ACS transported 4,571 immigrants to Liberia, only 1,819 of the settlers were still alive in $1843 .{ }^{47}$ Deaths were caused primarily by diseases. ${ }^{48}$

Besides diseases, several unique features of tropical farming posed problems for the emigrants from North America. For instance, the newcomers had to adjust to the pattern of seasonality during the farming period in Liberia. The two main farming seasons in Liberia are the wet and dry periods. This means that farming must be carried out promptly when the rains are available or farmers risk starvation or poor yields. ${ }^{49}$ The proximity of Liberia to the equator also guaranteed that its farming season is sharply divided into wet and dry periods. Liberia is situated between four degrees, twenty-two minutes and eight degrees, thirty-three minutes north of the equator. This means that temperatures are generally the same throughout the year. The closeness of Liberia to the equator ensures that it receives an ample supply of rain. However, the greatest quantity of this precipitation is concentrated in just four months: May, June, September and October. Some rains do fall in the rest of the year, but because of the scorching sun, most of the

\footnotetext{
${ }^{47}$ The figure includes the first group of immigrants that settled on Sherbro Island, east of Sierra Leone in 1820. See, The Census; Tom W. Shick, "A Quantitative Analysis of Liberian Colonization From 1820 To 1843 With Special Reference to Mortality," Journal of African History, XII, 1 (1971): 45-59.

${ }^{48}$ Ibid.

${ }^{49}$ Ruthenberg, Farming Systems in the Tropics, 14; Paul Richards, Indigenous Agricultural Revolution (Boulder, CO: Westview Press, 1985), 44-49;
} 
downpours are quickly lost to evaporation. Therefore, farmers have to time the planting season so that it coincides the rainy months. ${ }^{50}$

Adjusting to this particular rainfall pattern was a new experience for the colonists. Farming in the United States was determined more by variations in temperature, rather than by sharp alterations in rainfall. As a result, vegetables could be grown in most parts of the United States for nearly "three hundred days" (i.e., "March to November"). ${ }^{51}$ On the contrary, the planting period in Liberia was generally restricted to the early weeks of the rainy months. The heavy runoffs that usually followed the rains tended to wash away seeds and sprouts. During his visit to Liberia in 1824, Ralph Gurley the general agent of the ACS, attributed the negligible progress of agriculture to the colonists' unfamiliarity with tropical farming. He instructed Agent Jehudi Ashmun to prepare an "Agricultural Manual." Ashmun completed the handbook in 1825. It contained general information, according to Ashmun, "from the best sources at my command." On the subject of seasonality, Ashmun wrote:

Here you can find neither Winter, Spring, Summer nor Autumn . . . you must learn an entirely different way of farming ... It is vastly important that your new grounds should be cleared, well burnt, planted and fenced before these rains come on. It is not possible to do either, well, afterwards. ${ }^{52}$

In spite of Ashmun's manual, seasonality was a lingering problem. John B.

Pinney of New York, who served in Liberia as agent of the colony (1834-1835), gave the

\footnotetext{
${ }^{50}$ For a nineteenth-century account of the Liberian climate see, J. W. Lugenbeel, Sketches of Liberia: Comprising a Brief Account of the Geography, Climate, Productions, and Diseases, of the Republic of Liberia (Washington: C. Alexander, Printer, 1850).

${ }^{51}$ Sam B. Hilliard, Hog Meat and Hoecake: Food supply in the Old South, 1840-1860 (Carbondale: Southern Illinois University, 1972), 172-173.

${ }^{52}$ Ashmun, The Liberian Farmer, 3, 8.
} 
following advice to Methodist missionary John Seys of Liberia in 1859: "I observed by the paper that the cotton seed failed or was destroyed by too much rain ... by planting seeds near the close of the rainy season, say in October-the plant would bear all in the dry season and no balls would rot." Pinney assured Rev. Seys that his advice was based on the experience of someone who had planted Sea Island cotton in Liberia on November 24, 1840 and by January 1, 1841 “ . . a branch from the cotton planted six weeks . . . exhibited a beautiful white cotton of a very long and fine staple." 53

Another problem associated with farming that the newcomers had to confront was the general poor quality of Liberian soil. It was previously indicated that compared to soil in the United States, the quality of Liberian soil was inferior. Leaching can lead to soil degradation in two main ways. Obviously, it washes away valuable organic plant foods from the soil. In addition, leaching can accelerate the process of erosion by making the soil loose, thereby causing it to be washed away at a faster rate. When soil is washed away through erosion, it is generally deposited in areas where it is hardly useful to farmers (e.g., in streams). Thus, a considerable quantity soil is permanently lost. According to Stefan Von Gnielinski, 17 percent of the soil in Liberia is prone to erosion. ${ }^{54}$

To manage the marginal soil, farmers in the pre-Liberia era developed several ways to restore fertility to the land. The most widespread practice was to allow previously farmed land to lay fallow, sometimes for as long as fifteen years. A new portion of land (unused or mature secondary growth) was then cleared for the next farming season. This system, commonly called "shifting cultivation," gave old fields

\footnotetext{
${ }^{53}$ Liberia Herald, 4 January 1860.

${ }^{54}$ Stefan Von Gnielinski, ed., Liberia in Maps, 18.
} 
time to restore their vegetation. During the process of the regrowth, the old fields were invigorated by debris from decayed plants and animals.

Shifting cultivation may not have been a totally new experience for some of the American colonists. Former slaves from Southampton Virginia, for instance, had practiced shifting cultivation by "reopening land that had lain fallow." 55 The settlers would have discovered, however, that clearing the dense tropical undergrowth of Liberia was more arduous than cutting the sparse vegetation in Virginians, especially since working animals were very scarce. Animal-drawn ploughs, which the American emigrants had been accustomed to using, were not always available in Liberia. For a combination of reasons, disease being the obvious, draft animals such as horses and cattle were seldom used in the farming communities of the coastal regions of West Africa. But it must be noted that there is no guarantee that the availability of animal-drawn ploughs would have been advantageous to Liberian cultivators. Economic historian Anthony Hopkins has observed that the plough is inappropriate for farming in tropical West Africa because fields are laden with stubs, among other reasons. ${ }^{56}$ Still, Liberians did discover other areas where draft animals were highly beneficial. The scarcity of draft animals and the impact it had on commercial agriculture is discussed in more detail in Chapter V.

\footnotetext{
${ }^{55}$ Daniel W. Crofts, ed., Cobb's Ordeal: The Diaries of a Virginia Farmer, $1842-1872$ (Athens: University of Georgia Press, 1997), 64.

${ }^{56}$ For the arguments, see. Hopkins, An Economic History of West Africa, 36-37.
} 
From Towns to Farms: Settlement History and Agricultural Expansion

The Era of the Merchants

Although the ACS intended for the Liberian immigrants to cultivate staple crops for export, it realized however, that commerce was advantageous. The Society reasoned that the immigrants could become the intermediary in the commerce between the people of the interior and the foreign merchants on the Atlantic coast. The fledgling Liberian colony, as well as American merchants, could benefit from the trade. Consequently, the ACS founded the first settlements at locations that enabled the immigrants to assume an intermediary role in the transatlantic trade. These locations were prominent, well-known commercial centers. Take, for instance, Cape Mesurado where Monrovia (the original town) was established. Portuguese mariners and African traders had bartered at the Cape at least since the sixteenth century. ${ }^{57}$ One of the most important goods for Portuguese traders on the Windward Coast was the Malagueta Pepper, commonly called "grains of Paradise" in Europe. Until the 1700s, the grains of Paradise "formed the foundation of most spices and the flavoring of drinks and viands." ${ }^{, 58}$ Portuguese mariners purchased the Malagueta Pepper from the indigenous people at Cape Mesurado and other places along the pre-Liberian coast. Accordingly, the Portuguese named the region the Malagueta Coast. $^{59}$

\footnotetext{
${ }^{57}$ See J. Barbot, "A Description of North and South Guineas," in A Collections of Voyages and Travels, Vol VI ed. Awnsham Churchill, (London: J. Walthoe, 1704-1732), 109-138; Harry Johnston, Liberia, vol. 1, (London: Hutchinson \& Co., 1906); W. Bosman, "A New and Accurate Description of the Coast of Guinea," in A General Collection, Vol. 16, ed. J. Pinkerton, (London: 1806-1814).

${ }^{58}$ Johnston, Liberia, vol. 1, 58.

${ }^{59}$ Ibid., 37-59.
} 
When the immigrants arrived in 1822, Cape Mesurado was still a commercial center. European and American vessels bought slaves, which were very likely the principal trade items, along with camwood, gold, ivory, rice and water from the Cape. ${ }^{60}$ The founding of the first settlement at Cape Mesurado was intended to give the immigrants full control of the long-established trade on that part of the coast. Similar strategic locations were selected at other points along the Atlantic littoral.

During the first half of the nineteenth century, revenue from the transatlantic commerce was the primary source of income for the colonists. Liberian merchants were actively engaged in the commerce along the coast. As indicated earlier, Liberian-owned vessels plied the West African coast, selling manufactured goods from the United States and Europe and buying African products for sale overseas. ${ }^{61}$ Some of the merchants also served as agents for foreign companies. The merchants were mostly freed immigrants, the elite in the settler society. Dwight $\mathrm{N}$. Syfert determined that of the eighty-one merchants that operated between 1822 and 1847 , fifty-two had some form of literacy and forty-four were born free. ${ }^{62}$ These traders or "merchant princes" were prosperous and held influential positions in the government. Joseph J. Roberts, a wealthy merchant, was the first and sixth President of Liberia. Hilary Teage, another Liberian merchant prince, became Secretary of State. ${ }^{63}$

\footnotetext{
${ }^{50}$ Svend E. Holsoe, "A Study of Relations Between the Settlers And Indigenous Peoples of Western Liberia," African Historical Studies IV, 2 (1971): 331-362.

${ }^{61}$ Webster and Boahen, History of West Africa: The Revolutionary Years, 150-152; Syfert, "The Liberian Coasting Trade, 1822-1900."

${ }^{62}$ Dwight N. Syfert, “The Origins of Privilege: Liberian Merchants, 1822-1847," Liberian Studies Journal VI, 2 (1975): 109-128.

${ }^{63}$ Ibid.
} 
Trade proved to be more advantageous than agriculture during this early period.

Commerce was more reliable and it offered quicker returns. On the other hand, agriculture turned out to be highly unpredictable. One reason for the uncertainty was the immigrants' unfamiliarity with the mode of tropical agriculture. Many of the colonists, who attempted to become farmers in the early period, eventually switched to trade or became part-time farmers. The case of Reverend Colston Waring is illustrative. Waring is remembered almost entirely as a merchant prince. What is missing in most accounts about Waring's life is his early endeavor as farmer. ${ }^{64}$ One of the few narratives about Waring, the farmer, was recorded by Jehudi Ashmun in 1824:

The Rev. C. M. Waring was the first to adventure a large and valuable amount of labor and funds, in a then novel experiment of an untried crop, in African lands. In the latter part of $1824 \ldots$ he brought nearly the whole of a plantation of ten acres under cultivation, at a very great expense ... The whole plantation miscarried. ${ }^{65}$

Even though Waring continued to farm (in 1832 he cultivated 6 acres of coffee ${ }^{66}$ ) he apparently devoted much of his time and energy to commerce. The decision turned out to be a wise choice for Waring. He reportedly earned a substantial $\$ 70,000$ from his business in $1830{ }^{67}$ Ashmun mentioned two others, Lewis Cook and Rev. Lott Carey, who also tried unsuccessfully to become farmers. The causes for the failures ranged from

\footnotetext{
${ }^{64}$ See Sawyer, The Emergence of Autocracy in Liberia, 110; Akpan, "The Liberian Economy," 11-12.

${ }^{65}$ Gurley, Life of Jehudi Ashmun, Appendix, 131.

${ }^{66}$ Annual Report, 1834, 8.

${ }^{67}$ P. J. Staudenraus, The African Colonization Movement, 154.
} 
"an error in the proper season for planting ... rice birds, and monkeys" to the lack of "an improved agriculture. ${ }^{.68}$

The attempt by the settlers to protect trade, which generated nearly all the revenues for the colony constantly teetering on the verge of bankruptcy, was certainly a paramount consideration in the decision to declare independence in 1847. As Liberia became more and more dependent on revenues from trade, the government tried to regulate commerce so that it could effectively collect custom duties from foreign vessels. One measure adopted by the authorities was the designation of specific locations on the Liberian coast as ports of entry and the insistence that foreign vessels disembark only at those harbors. Usually, foreign merchants refused to recognize the authority of the Liberian Government, contending that the Commonwealth of Liberia was not a sovereign nation and as such it did not have the jurisdiction to regulate trade. Eventually, the Commonwealth of Liberia declared its independence in 1847, apparently with the approval of the ACS. ${ }^{69}$

\section{The First Agricultural Settlement}

Although commerce was the primary choice of many Americo-Liberians during the first half of the century, some of the immigrants were determined to succeed as farmers. The Virginians, who arrived in Liberia in 1825 and founded the first agricultural community, may be regarded as the pioneers of commercial agriculture. Many of the newcomers were from rural Virginia. Upon disembarkment, they insisted that they were

\footnotetext{
${ }^{68}$ Ibid., 131-132.

${ }^{69}$ See Sawyer, The Emergence of Autocracy, 90-93.
} 
farmers and therefore wanted to "remove to their plantations at once." ${ }^{\text {" } 70}$ At the time there were no farming communities in the colony, even though since his appointment in 1822 Ashmun had enjoined the colonists to occupy the farmlands that had been distributed to them. The farmlands or plantations were located about 3 miles from the town lots. ${ }^{71}$ But the colonists failed to occupy their plantations. Ashmun attributed the failure to the poor quality of land at the Cape. He wrote that the land was mostly "rocky ... sandy and unproductive" and the few places suitable for cultivation were difficult to clear because of the "thick and lofty forest.","2

In 1825, Ashmun had acquired a large tract of land in the back of Monrovia from the Dei-speakers who reportedly ceded the Cape to the colonists. The land, which Ashmun described as the "finest farming lands in the world," was situated on the Saint Paul River, one of the largest bodies of water in the country. It was on this land that the Virginian settlers established the first agricultural settlement. Ashmun named the farmland the St. Paul Settlement which was later changed to Caldwell, for Elias B. Caldwell. Caldwell was a founding member of the ACS and at the time, the Secretary of the organization.

Ashmun and his bosses in Washington, D.C. may have been inspired with activities in Caldwell because in 1828 a second settlement, Millsburg, was founded on a

\footnotetext{
${ }^{70}$ Annual Report, 1826, 37-38.

${ }^{71}$ Ibid., 38.

${ }^{72}$ Gurley, Life of Jehudi Ashmun, Appendix, 128-129.
} 
portion of the same land that had been relinquished to the colony in $1825 .^{73}$ Millsburg was situated about 10 miles north of Caldwell, on the opposite side of the St. Paul River. It was linked to Monrovia by small river crafts. Millsburg had been founded primarily as a farming community, however, its location was significant to the commercial class in Monrovia. Millsburg was situated on the same trade route with the famous commercial town of Bopolo or Boporo. Bopolo, located about 75 miles north of Monrovia, was the the largest town between Guinea and the Liberian coast. Commodities destined for the coast from Guinea went through Boporo, then Millsburg and finally Monrovia. In 1822, Boporo was controlled by a loose political union called Condo. Its leader, Sao Boso of the Manding ethnic group of Guinea, vied with the Gola-speakers who lived on the edge of the forest northwest of the St. Paul River and the Dei-speakers for control of the Boporo trade route. ${ }^{74}$ (See Figure 3.)

\footnotetext{
${ }^{73}$ Millsburg is a combination of the names of Rev. Samuel J. Mills and Professor Ebenezer Burgess. Both men had traveled to Africa on behalf of the ACS in 1818 to conduct a reconnaissance mission. Mills died on the return voyage.

${ }^{74}$ For a history of Boporo see, Svend E. Holsoe, "The Manding in Western Liberia: An Overview," Liberian Studies Journal, 7, 1(1976-77), 2. Svend E. Holsoe, "The Condo Confederation in Western Liberia," Liberian Historical Review, 3, 1(1966): 1-28.
} 


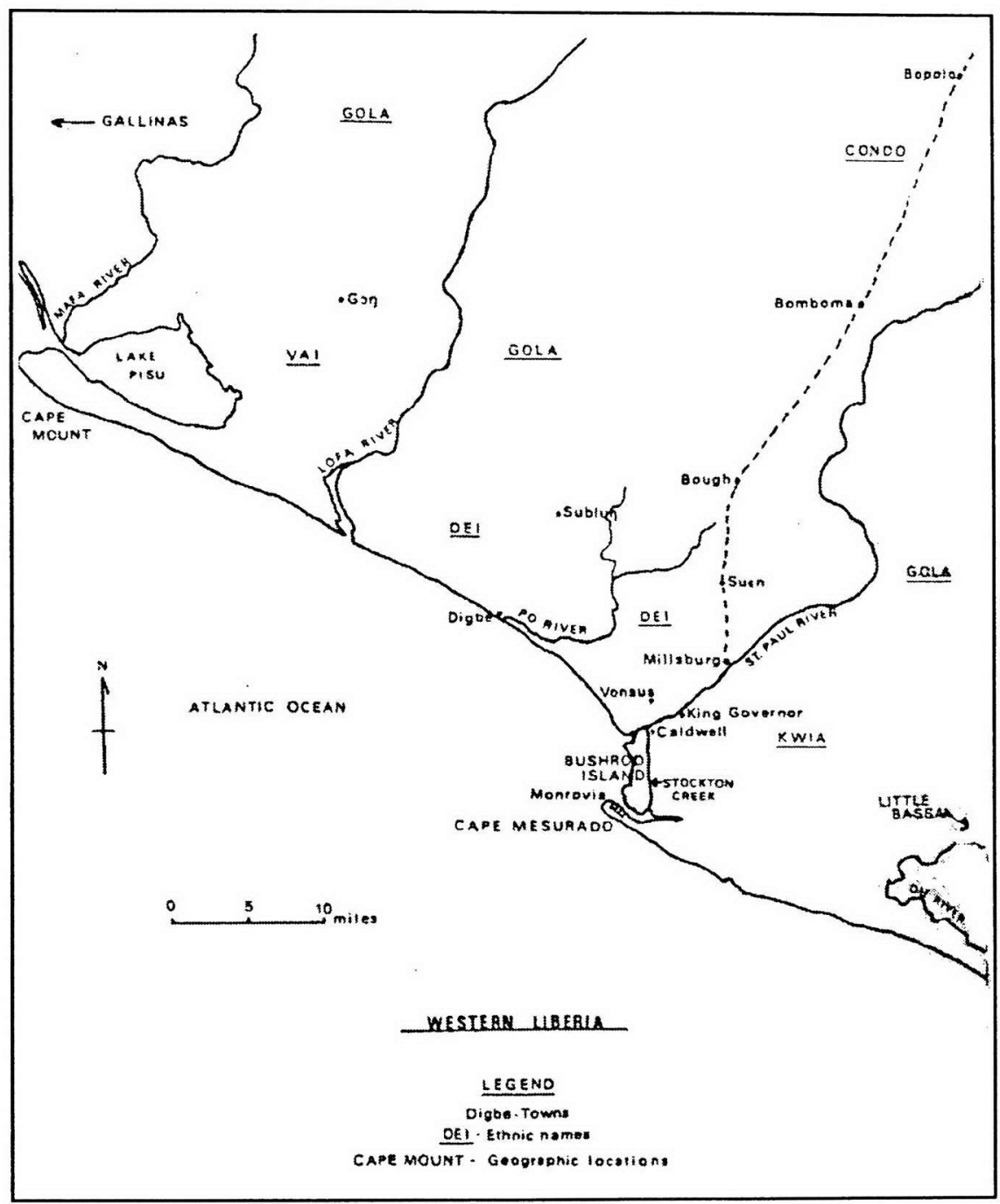

Figure 3. Cape Mesurado. (Reprinted by permission of the African Studies Center, Boston University, Holsoe, 1971.) 
Ashmun had actually established Millsburg at the request of the Dei leaders who were steadily losing their position as middlemen to the colonists at the Cape. The Dei ethnic group hoped to retain some control over the interior trade by forging an alliance with the militarily superior colonists. They promised not to interfere with the trade from the interior, if Ashmun agreed to establish a settlement at the location they chose. The location was Millsburg. ${ }^{75}$

Caldwell and Millsburg were the only two interior settlements founded in the 1820s. At the time of independence in 1847 , a total of probably nine farming communities had been established in the interior of the three counties that made up the Republic of Liberia. All of the communities were located along the banks of rivers. Probably six or seven of them were situated in the vicinity of the St. Paul River in Montserado County. Several of these early frontier towns (along with those that had been established in the second half of the century) became the centers for sugar and coffee production.

\section{Sugar Cane and Coffee Lead the Way}

Even though commerce was the predominant economic activity in Liberia, some of the colonists did attempt to cultivate staple crops. Sugar cane and coffee became the two favorites. The decision to grow sugar cane and coffee in Liberia was spurred by a highly favorable international market driven primarily by increasing worldwide consumption. Between the 1830s and 1850s, the global demand for sugar and coffee had

\footnotetext{
${ }^{75}$ Gurley, Jehudi Ashmun, 363-365. Svend Holsoe provides a summary of the relationship between the colonists and the local ethnic groups at the coast. Holsoe, "A Study of Relations Between Settlers and Indigenous Peoples in Western Liberia, 1821-1847" African Historical Studies, IV, 2(1971): 331-362.
} 
exceeded the supply. In both the sugar and coffee industry, the void created as the result of the destruction of the Haitian sugar and coffee plantations in the aftermath of the 1791 Revolution remained largely unfilled. Sugar manufacturers in Latin America expanded production in spite of the precipitous decline in prices (e.g., prices fell by 30 percent from 1840 to 1850 and by an additional 25 percent in the sixties and seventies). ${ }^{76}$ In the United States, the rush to grow sugar cane during the 1850 s, heightened by falling cotton prices, led to what a planter described as the "sugar fever."77

Like sugar, weakened coffee prices did not slow production because demand continued to rise. For most of the first half of the century, coffee prices declined. In 1821 , for instance, the price of coffee was 25 cents a pound, but dropped to a low of about 11 cents a pound by $1825 .^{78}$ The decline continued for approximately the next three decades. ${ }^{79}$ In spite of the unattractive price, cultivators expanded production to meet rising demand. In the United States the growing rate of consumption was quite noticeable: coffee drinkers increased their annual intake from three pounds in 1830 , to five and a half pounds in 1850 and eight pounds by $1859 .{ }^{80}$ It was such growing demand for coffee-and sugar-particularly in the United States, that motivated the ACS and the Liberian Government to promote cultivation in Liberia. Many of the new immigrants,

\footnotetext{
${ }^{76}$ Sidney W. Mintz, Sweetness and Power: The Place of Sugar in Modern History (New York: Penguin Books, 1985), 144; Klein, African Slavery in Latin America and the Caribbean, 89-137.

${ }^{77}$ Sitterson, Sugar Cane Country, 27-28.

${ }^{78}$ Pendergrast, Uncommon Grounds, 47.

${ }^{79}$ Ibid., V. D. Wickizer, The World Coffee Economy: With Special Reference to Control Schemes (California: Stanford University, 1943).

${ }^{80}$ Pendergrast, Uncommon Grounds, 46.
} 
who were mindful of the favorable market for sugar and coffee in the United States, eagerly embraced the opportunity to cultivate both commodities in Liberia.

In the first half of the century, the government and the colonists adopted several measures to encourage sugar cane and coffee cultivation. One of the earliest steps was a change in the existing policy of land distribution. The ACS announced in 1830 that each new immigrant family that chose to live 3 miles beyond the town would receive 50 acres of farmland, and in addition, the family could purchase 50 adjoining acres at 25 cents per acre. ${ }^{81}$ This was more than three times the land that had previously been allocated.

Another incentive aimed at stimulating commercial agriculture was prize money. In 1834 the ACS reported that "premiums" had been offered to "encourage agricultural industry." ${ }^{82}$ A detailed list of the premium was published in 1841. The highest award to a single individual was $\$ 100$ for coffee: "over five thousand trees raised in any one year . . . in the best condition." Sugar was one of three items that was assigned the second highest cash award. An award of $\$ 50$ was given for the "largest quantity of manufactured sugar." The rest of the prizes were set aside for vegetables and domestic animals. ${ }^{83}$ No one won the maximum prize for "coffee trees over 5,000 ." The $\$ 50$ prize for sugar was also unclaimed. Three coffee growers received secondary awards. They were Samuel Benedict ( $\$ 50$ for 3960 coffee trees), James Moore ( $\$ 37.50$ for 3,300 trees), Lewis Sheridan ( $\$ 25$ for 3,000 trees) and Samuel Claborn ( $\$ 20$ for 2,000 trees). ${ }^{84}$

\footnotetext{
${ }^{81}$ AR \& CJ, 1843, 303-304.

${ }^{82}$ Annual Report, 1834, 7-8.

${ }^{83}$ Ibid., 1841, 49.

${ }^{84} \mathrm{AR} \& \mathrm{CJ}, 1841,215$.
} 
A third measure adopted to advance agriculture was the formation of public farms or colonial farms. The first public farm was opened on Bushrod Island, near Monrovia, probably in 1837. Additional farms were established in the settlements of Bassa Cove and Sinoe. Public farms were intended as experimental agricultural stations. Indigent settlers were required to work on the public farms. This latter function appears to give credence to Political Scientist, Amos Sawyer's claim that the farms were "labor camps," where poor settlers were coerced to work. He concluded that the farms were "counterproductive" to agricultural development. ${ }^{85}$

Perhaps the public farms were "labor camps," but they were not "counterproductive" to agriculture. As an experimental station, the public farms provided training to farmers in tropical agriculture, particularly in the cultivation of coffee and sugar cane. ${ }^{86}$ In 1841 Governor Thomas Buchanan (1839-1841) contacted two "white men," who were visiting Liberia from the United States to superintend the Bushrod Island public farm. One of them, Mr. Jenks or Jenkes, was reported to have had considerable expertise in sugar cultivation and manufacturing sugar. The second person, Mr. Harzen, was an expert on coffee production. Harzen died of fever shortly before Buchanan could arrange the terms of his employment. Mr. Jenks may have succumbed to the fever as well, because he also passed away suddenly. ${ }^{87}$

Jenks is remembered as the man who taught the colonists improved methods of manufacturing sugar. Before Jenks' employment, the public farm manufactured the first

\footnotetext{
${ }^{85}$ Sawyer, The Emergence of Autocracy, 88-89.

${ }^{86} \mathrm{AR} \& \mathrm{CJ}, 1838,5 ;$ Annual Report, 1841, 36.

${ }^{87}$ Annual Report, 1842, 14-15; 1843, 12.
} 
quantity of cane sugar. Governor Buchanan later explained that the quantity was less than what should have actually been realized from the cane. The Governor attributed the problem to "the greatest possible disadvantage," that included poor facilities and the lack of knowledge of making sugar. ${ }^{88}$ Buchanan hired Jenks not too long afterward. afterward. During his brief tenure, Jenks conducted experiments at the public farm that confirmed the soil and the climate were suitable for sugar cane and taught the farmers to make sugar more efficiently. ${ }^{89}$ In 1842 , shortly after the sugar expert's passing, the Public Farm manufactured "between two and three thousands pounds of good sugar." A small quantity of the sugar was dispatched to the United States as sample..$^{90}$ Subsequently, some farmers began to manufacture sugar on their farms. In 1842, the Liberia Herald reported that "Mr. Willis [Cyrus] has made 1,000 pounds of sugar" and another colonist expected to make "4,000 pounds."91 The colonists attributed the production of sugar to the lessons they learnt from Jenks. Doctor J. Lawrence Day, the Colonial Physician in Liberia at the time, eulogized Jenks in this Shakespearean prose: "The good he [Jenks] did, lives after him." 92

A final step taken to promote commercial farming in the early period was the formation of agricultural associations. Records show that in 1829 farmers in Caldwell (i.e., the original agriculture settlement), “associated themselves into an Agricultural

\footnotetext{
${ }^{88}$ Ibid., 1841, 36; Ibid., 1843, 12.

${ }^{89}$ Ibid.

${ }^{90}$ Ibid., 1841, 36; AR \& CJ, 1842, 256.

${ }^{91}$ Liberia Herald, 17 March 1842.

${ }^{92}$ Annual Report, 1843, 12.
} 
Society." The report further noted that the members held "weekly meetings" at which time discussions about the "progress on their plantations" were announced. ${ }^{93}$ A second account described an agricultural association that was organized in 1838 "to encourage the cultivation of sugar-cane, and the manufacture of sugar." It was recorded that the acting Governor of the colony, Anthony D. Williams, acquired "a few shares of the stock $\ldots$ in behalf of the Society." 94

By the end of the 1840s, not very much had been accomplished in commercial agriculture. According to the census of 1843, 54 acres of sugar cane and 21,197 coffee trees were cultivated in Liberia. ${ }^{95}$ No sugar was exported, aside from the samples sent to the United States. A number of reasons are given in the archives for the colonists' inability to manufacture sugar and cultivate coffee. They include inadequate knowledge of tropical farming, the scarcity of draft animals, the lack of farming equipment, the immigrants' preference for commerce and indolence. ${ }^{96}$

Some modest progress was, however, made in the period. The most notable achievement was in coffee cultivation. It seems that the first quantity of coffee exported for sale occurred in 1848. The export consisted of "thirteen bags of coffee (averaging 110 pounds to the bag) raised on the plantation of Stephen A. Benson." ${ }^{\text {,97 }}$ A report from the United States, printed in "The African Repository and Colonial Journal” of 1848,

\footnotetext{
${ }^{93}$ Ibid., 1829, 12-13.

${ }^{94} \mathrm{AR} \& \mathrm{CJ}, 1838,5$.

${ }^{95}$ The Census.

${ }^{96}$ See, for example, Liberia Herald, 17 March 1842; AR \&CJ, 1843, 303-304, 329; Annual Report, 1856, 30 .

${ }^{97} \mathrm{AR} \& \mathrm{CJ}, 1848,286$.
} 
expressed satisfaction with the commodity. The report indicated that Liberian coffee was "equal to any in the world." 98

\section{Social Status of the Planters}

It is important at this point to emphasize the social background of the planters of this early period. The information is scanty. Yet, from the paltry evidence the following picture emerged. The largest coffee planters owned 6,000 trees. They were Samuel Benedict, Lewis Sheridan and James Moore. Each of the men possessed 6,000 coffee trees. ${ }^{99}$ These are the planters that won the secondary prizes for the highest number of coffee trees in 1841. William Weaver was the fourth largest farmer, with 2,000 trees.

The four men were educated and apparently well off. Samuel Benedict, who emigrated from the State of Georgia in 1835 , is described in a 1851 publication as a "scholar and a man of fortune."100 Judge Benedict, as he was commonly called, held a number of influential positions in Liberia. The most prestigious office must be President of the Constitution Convention, the body that wrote the first constitution for the new republic. Lewis Sheridan could read and write. The early nineteenth-century Liberian historian, Abayomi Karnga, characterized Sheridan as "a distinguished Negro capitalist."101 Sheridan had spearheaded the founding of Bexley, one of the earliest inland settlements. There are two "James Moores" in the census of 1843 and it is unclear

\footnotetext{
${ }^{98} \mathrm{AR} \& \mathrm{CJ}, 1848,286$.

${ }^{99}$ Information obtained from The Census.

${ }^{100}$ Helen Cross Knight, The New Republic (Boston: Massachusetts Sabbath School Society, 1851), 149.

${ }^{101}$ Abayomi Karnga, History of Liberia (Liverpool, United Kingdom: D. H. Tyte \& Co., 1926), 26. See also, Knight, The New Republic.
} 
which one was the coffee planter. Both men are literate. The older Moore is an "apothecary," and the father of the second James Moore. No profession is listed for the younger Moore. An excerpt from the 1851 obituary of James Moore, Sr. stated that "He was not a graduate in medicine; though, being a man of good sense, and having given much attention to the observation of diseases, he made himself a useful medical practitioner." ${ }^{102}$ It is likely that the older James Moore, the pharmacist, owned the 6,000 coffee trees. William Weaver, the man with the 2,000 trees was literate. He emigrated in 1824. Colonel Weaver, as he was popularly called, served in a number of capacities, including commander in the colonial militia. When he died, probably in 1852 , Weaver was a member of the National Legislature. ${ }^{103}$

Fewer farmers were involved in sugar cane cultivation and sugar manufacturing. A total of 54 acres of cane was counted in $1843 .{ }^{104}$ Two planters were enumerated: Cyrus Willis and G. Moore. The men grew 10 acres and 4 acres respectively. Both men were farmers and were uneducated. The remaining 40 acres were held by two institutions: the Colonial Farm or Public Farm (30 acres) and the M. E. Mission (10 acres). The M. E. Mission was very likely the Methodist Episcopal Mission Manual Labor School founded in the 1830 s for orphaned children. ${ }^{105}$ The financial status of the sugar producers, particularly Willis and G. Moore is unknown. However, a story in the 1842 edition of the Liberia Herald had this much to say:

\footnotetext{
98 AR, 1851, 325.

${ }^{103} \mathrm{AR}, 1852,241-242$.

${ }^{104}$ The Census.

${ }^{105}$ Knight, The New Republic, 149.
} 
Rev. Mr. Wilson at the Manual Labor farm of the M. E. Mission ... will make 4,000 pounds [sugar] and Mr. Willis has made 1,000 pounds. All this has been done with an insufficient temporary affairs of a mill which they borrowed from Mr. Moore. ${ }^{106}$

From the sketchy data, the following conclusions can be drawn. At the time of the census in 1843 , four of the six large principal planters were educated. The level of education of three of the men (i.e., Benedict, Weaver and Moore) is described as "liberal," obviously the highest rank among categories such as, "reads, spells and reads and writes." Clearly the four coffee planters were among the tiny group of prosperous Americo-Liberians. They were from the elite, upper class of the Americo-Liberian society. Members of this class were generally educated and relatively wealthy. This same class produced the wealthy "merchant princes"and five of the first presidents of Liberia. ${ }^{107}$ As far as it can be established, four of the five presidents were primarily merchants.

\section{The Secondary Staple Crops}

It is worth mentioning that during this period, the Liberian immigrants also attempted to cultivate other minor staple crops for export. Among the principal "secondary" commodities were groundnuts or peanuts (Arachis hypogaea) and arrowroot (Maranta arundinacea) ${ }^{108}$ Arrowroot and groundnuts (along with corn, cassava or

\footnotetext{
${ }^{106}$ Liberia Herald, 17 March 1842.

${ }^{107}$ Wiley, Slaves No More, 308; Syfert, "The Origins of Privilege."

${ }^{108}$ Wiley, Slaves No More, 146; ACS, 1841, 36-37; ACS, 1829, 13.
} 
manioc and potatoes) were among the American food crops introduced into Africa from the sixteenth century and onward. ${ }^{109}$

Peanuts may have been cultivated for the first time in Liberia sometime between the $1820 \mathrm{~s}$ and $1840 .^{110}$ The expanding role of peanuts in industries and households in Europe and the United States from the nineteenth century made them a valuable export commodity. Administrators in the colony recognized the commercial value of peanuts and attempted to promote their cultivation. In 1840 a premium of $\$ 10$ was awarded to Peggy Hope for "one and-a-half acres." 111 Three years later, 31 acres of land were reported to be cultivated with peanuts. ${ }^{112}$

There is no indication that peanuts were exported from Liberia in the first half of the 1800 s, except a controversial story that historian George Brooks uncovered which states otherwise. The account in question was published in the "Colonization Herald" in the United States in March 1839 and cited in a United States House of Representatives Report. It stated that "a quantity of pea or ground nuts" from Liberia was sold in the ${ }^{109}$ Herbert G. Baker, Plants and Civilization (Belmont, California: Wadsworth Publishing Company, Inc., 1970), 55-56. For further details on the transference of American food plants see, Alfred Crosby, The Columbian Exchange: Biological and Cultural Consequences of 1492 (Westport, Conn.: Greenwood Press, 1972).

${ }^{110} \mathrm{An}$ account in the Annual Report of 1829 indicates that peanuts was one of the "products now rearing in the Colony"; Annual Report, 1829, 13. Yet, George Brown, an American missionary who lived in Liberia suggested that peanuts were first cultivated sometime during his residency in Liberia between 1836 and 1842. He wrote, "some of them [the colonists] are beginning to cultivate peanuts." George S. Brown, Brown's Abridged Journal, Containing a Brief Account of the Life, Trials and Travels of Geo. S. Brown, Six Years a Missionary in Liberia, West Africa: A miracle of God's Grace, (Troy, New York: Press of Prescott \& Wilson, 1849), 370. In 1841 a little over 8 acres of peanuts were reportedly cultivated; Annual Report, 1841, 36-37.

${ }^{111} \mathrm{AR} \& \mathrm{CJ}, 1842,215$.

${ }^{112}$ The Census, 394. 
United States in 1838 for a profit of " $\$ 12,000 . "$ "13 Brooks conclusion that "in the absence of substantiating evidence," the peanuts must have been obtained from some place outside of Liberia, appears reasonable. It is highly unusual that the record of such an outstanding transaction has not been found in the archives of the ACS, since the organization was consistently trying to convince its critics that Liberia was economically viable. Finally, Brooks explained that peanuts did not thrive in Liberia (i.e., "the area south of Sierra Leone") because the soil was unfit for its cultivation. ${ }^{114}$ Liberia's warm climate and narrow belt of coastal sand are somewhat ideal for growing peanuts, except that the rainfall in the region is about twice as much as the crop requires. ${ }^{115}$

Arrowroot, the other major secondary crop, was used principally as a source of starch. In the United States (and probably England), arrowroot flour was ordinarily used as an essential ingredient in the foods of infants and sick patients. ${ }^{116}$ Many of the colonists in Liberia relished the "wholesome" taste of arrowroot flour. In the absence of wheat-flour, they found arrowroot even more desirable. According to J. W. Lugenbeel, the American resident physician in Liberia, some of the immigrants prepared bread entirely from arrowroot flour. Lugenbeel further noted that the flour could be combined with rice to make delicious "rice bread" or sweet potatoes to give "fine biscuits," "pie-

${ }^{\Pi 3}$ George E. Brooks, "Peanuts and Colonialism: Consequences of the Commercialization of Peanuts in West Africa, 1830-70," Journal of African History, 16, 1 (1975), 51.

${ }^{114}$ Ibid., 50.

${ }^{115}$ The Liberian Coast (along with the West African littoral) receives at least forty inches of rain. According to Jan S. Hogendorn., peanuts will prosper in and area with "a minimum of 22-24 inches of rainfall." Jan S. Hogendorn, Nigeria Groundnuts Exports: Origins and Early Development (Zaria, Nigeria: Ahmadu Bello University Press, 1978), 41.

${ }^{116}$ AR \& CJ, 1845, 341; St. Cloud Tribune, (Florida) 23 December 1909); Leslie S. Cobley, An Introduction to the Botany of Tropical Crops (New York: Longman Inc., 1976), 126-127. 
crust" and "cakes" were also made from arrowroot flour." Arrowroot was among the first crops to be cultivated in the colony. It was listed among the cultivated crops in 1829. 118 In the "Statistics" of 1841, "27 acres in Arrow Root" is recorded, although arrowroot is not included in the Census of $1843 .{ }^{119}$ Sometime during the second half of the 1840s Lugenbeel mentioned that "arrow-root has been used pretty extensively in Liberia. . ..."120

A summary of the main developments relating to commercial agriculture shows that in spite of the advantages that commerce had over agriculture, some of the Liberian colonists did cultivate export crops. Sugar cane and coffee were the two chief preferences. The Liberian government encouraged the cultivation of sugar cane and coffee by offering premiums to farmers. Experimental stations for teaching the rudiments of tropical agriculture were also established. Sugar production was one of the benefits of the station or public farm. Finally, commercial agriculture was carried on almost exclusively by the small class of educated and relatively wealthy immigrants. It remains to be seen if this class will continue to be the vanguard in commercial agriculture in the next period. The subsequent chapter, which focuses on sugar production, should provide part of the answer.

\footnotetext{
${ }^{\Pi 7} \mathrm{AR} \& \mathrm{CJ}, 1845,341 ;$ Lugenbeel, Sketches of Liberia, 25-26.

${ }^{118}$ Annual Report, 1829, 13.

${ }^{119}$ Ibid., 1841, 37.

${ }^{120}$ Lugenbeel, Sketches of Liberia, 26.
} 


\section{CHAPTER III}

\section{THE ERA OF SUGAR CANE AND SUGAR PRODUCTION, ca. 1850-1880s}

Give us two or three industrious, intelligent immigrations; let them have a little money-for you know, however combustible the fuel, a little heat is necessary to create combustion ... let them have a little heap of money, and we will soon astonish you.

-Hilary Teage ${ }^{1}$

This chapter will consider the efforts that were made to grow sugar cane and manufacture sugar from 1850 through the $1880 \mathrm{~s}$, when production finally came to an end. The chapter is organized into several major themes. They include a brief discussion on the major resources that were required to make sugar, a description of the sugarproducing region, a synopsis of the individual role of the leading sugar manufacturers, and a consideration of the obstacles that poorer farmers faced. In the remaining sections, an attempt will be made to estimate the total cost of the investment that was made in the sugar industry and the overall quantity of sugar that was manufactured. I will first present an overview of how the growing demand for sugar in Europe and the United States stimulated production in Liberia.

\section{International Stimuli to Sugar Production in Liberia}

Liberia's brief but somewhat impressive history of sugar production was precipitated almost entirely by global circumstances. First and foremost, it was the favorable market for sugar, stimulated by an ever-expanding demand for sugar among the

\footnotetext{
AR, 1851, 269.
} 
working classes in Europe and the United States, that provided the catalyst for sugar cane cultivation in Liberia. By 1850 , the prospects for manufacturing sugar in Liberia, seemed highly favorable. Even though the price of sugar had fallen for most of the previous half century, rising global consumption spurred production. The increase in production persisted because the number of sugar consumers in Europe and the United States was also growing. Moreover, as the population of sugar users expanded, so did its utility. In Britain, for instance, consumers were using sugar increasingly in the preparation of an assortment of foods, like jams, puddling and breads. ${ }^{2}$ As a result, sugar consumption constituted a significant portion of the caloric intake. In 1852, the United Kingdom gulped "a billion pounds" of sugar, up from "300 million pounds" earlier in the $1800 \mathrm{~s}^{3}$

Sugar production in Liberia was even more intimately tied to conditions in the United States. The breakdown of cotton prices in the 1820 s and 1830 s, followed by the rise in the sugar tariffs, greatly stimulated the expansion of sugar production or the "sugar fever" in the United States in the 1850s. ${ }^{4}$ Liberia's preoccupation with sugar, which began in the second half of the 1850 s, occurred in the same period as the American "sugar fever." In the sixties, Liberian planters also saw a greater opportunity to sell their sugar in the United States when American sugar cane farms were destroyed as the result of the civil war. Conversely, the reconstitution of the American industry by 1880 proved to be a disaster for Liberian farmers who were unable to compete with the much larger and better financed sugar producers in the New World.

\footnotetext{
${ }^{2}$ Mintz, Sweetness and Power, chapter 3.

${ }^{3}$ Ibid., 143.

${ }^{4}$ Sitterson, "Sugar Cane Country." 24-28.
} 
Another direct link between sugar production in Liberia and developments in the United States was the rise in immigration to Liberia in the 1850s and 1860s. Growing racial prejudice in the United States at the time contributed to the increased immigration. Prior to the 1850 s, immigration remained low because many free blacks in the United States associated the ACS with pro-slavery forces. ${ }^{5}$ The enactment of the Fugitive Slave Law in 1850, which authorized Federal Agents to return the runaways to their owners, led some blacks to reconsider their decision not to emigrate to Liberia. Augustus Washington, who became a wealthy sugar manufacturer, stated that it was the "Fugitive Slave Bill" and other discriminatory laws that prompted him to leave the United States. ${ }^{6}$ The following comments by Henry Johnson, who arrived in Liberia with his family from New York in 1866, further demonstrate how racial prejudice motivated some free blacks to relocate to Liberia.

Do you know what I came for? [Johnson to his American visitor] Because I got tired of being called Henry. I was in the Brokers' Board, and no matter what I bought or sold, no matter what my dealings with my associates, I was never called Mr. Johnson; it was always Henry. I got sick of such humiliation, and determined to come to Liberia. ${ }^{7}$

In the end, it was the combination of all these international forces, like the steady demand for sugar, the opportunity to sell Liberian sugar in the United States and American racism that intersected to stimulate sugar production in Liberia.

\footnotetext{
${ }_{5}^{5}$ See, Redkey, Black Exodus, Introduction; Wilson Jeremiah Moses, ed., Liberian Dreams: Back-to-Africa Narratives from the 1850s (Pennsylvania: The University of Pennsylvania Press, 1998), Introduction.

${ }^{6}$ Moses, 130-131.

${ }^{7} \mathrm{AR}, 1877,109$.
} 
Although the worldwide market for sugar was favorable, Liberian farmers nonetheless, faced a problem that has plagued sugar manufacturers ever since the first sucrose was invented in the Islamic and Mediterranean World sometime after $700 \mathrm{~A} . \mathrm{D}{ }^{8}$ Sugar cane cultivation requires large amounts of labor, capital and land. Liberian farmers had access to sufficient land, even though the price of land for sugar cane cultivation rose rapidly during the height of the sugar era. Entrepreneurs, were scarce; as indicated in the previous chapter, the majority of the immigrants were uneducated, unskilled or semiskilled. Fortunately, there was a small core of resourceful settlers that proved to be efficient planters and businessmen. So, the most critical challenge that the farmers faced, like the pioneers of sugar manufacturing in the Islamic and Mediterranean World, was the scarcity of labor and capital.

Labor requirement is especially critical because a number of the stages of production, for example, harvesting, grinding and boiling the cane juice, closely follow one another. This means that the producer must have a workforce in place for each of these stages. Any delay in carrying out the next step in production could lead to lower quality of sugar. The first stage in sugar-making is to clear the land and dig strings of holes or trenches and place two feet long pieces of old cane stalk in them. Gestation takes anytime from nine to eighteen months, at which time the field must be kept free of weeds. When the cane is ripe, it has to be harvested and transported to the mill for grinding almost immediately. Any prolonged delay could compromise the quality of

\footnotetext{
${ }^{8}$ Klein, African Slavery, 8-10; Curtin, The Rise and Fall of the Plantation Complex, 3-16.
} 
manufactured sugar. At the mill, a workforce is maintained to carry out tasks like feeding the cane between the "teeth" or cylinders so it can be crushed and the juice extracted. The juice has to be boiled in a matter of hours or the quality of the finished product could similarly be jeopardized. ${ }^{9}$

The large amount of labor required to make sugar helps to explain why from the time it was first invented, sugar has developed an intimate relationship with slavery. From Asia, through the Mediterranean plantations and then the New World, slaves have been unwilling partners in the forward march of sugar. ${ }^{10}$ Many of the Liberian settlers had themselves been slaves on sugar cane plantations in the United States and the Caribbean. Opposition to slavery in Liberia by the ACS and the immigrants made the recruitment of slaves for commercial agriculture in Liberia very unlikely. So, even if some Liberian farmers wanted to exploit the age-old system of slavery, they could not do so without incurring the wrath of their sponsors in the United States. ${ }^{11}$

Capital, the next necessary input in sugar manufacturing, could also be considerable. Two major pieces of equipment, a sugar cane mill and several kettle are required to make sugar. Liberian planters imported both pieces of equipment from the United States and England. ${ }^{12}$ The farmers used mills that relied on animal and human

\footnotetext{
${ }^{9}$ See, Dunn, Sugar and Slaves, 191-201.

${ }^{10}$ Klein, African Slavery; Dunn, Sugar and Slaves; Richard Sheridan, Sugar and Slavery (Barbados: Caribbean, 1974).

${ }^{11}$ In the 1930s, a League of Nations Commission of Inquiry (with prompting from the United States) concluded that forced labor existed in Liberia and the practice was somewhat similar to slavery. See, I. K. Sundiata, Black Scandal: America and the Liberian Labor Crisis (Philadelphia: Institute for the Study of Human Issues, 1980).

${ }^{12} \mathrm{AR}, 1861,125$; Ibid., 1872, 284. There are reports (cited in this chapter) that sugar cane mills were manufactured in Liberia, although it is not clear how they were invented.
} 
traction and steam. However, all of the planters preferred the steam engine mills mainly because it cut down on labor and saved time in the process. At the time, the price of the steam engine ranged from $\$ 6,000$ to about $\$ 2,000 .^{13}$ A single kettle cost an estimated $\$ 750$ in the United States ${ }^{14}$. Given that farmers used two or three kettles at a time for making sugar, the price of the kettles were no less than $\$ 1,500$ at the time. Therefore, a farmer would need at least $\$ 3,500$ for the kettles and the steam mill. This sum did not include the charge for the construction of the boiling house or sugar house, used in the final stages for manufacturing sugar.

Those planters, who could only afford to purchase mills powered by oxen (called wooden mills), also needed substantial capital. The price of a wooden mill was no less than $\$ 500 .{ }^{15}$ In addition, the cost of operating the wooden mill could rise even higher because the draft animals died frequently from disease and exhaustion. (The causes are discussed in details in Chapter V.) To turn the cylinders of the mill for grinding the cane, a number of oxen were yoked individually to the mill by several long poles (hence, the name wooden mills) forming a circle. As the animals moved, a worker fed individual sugar cane stalks between the rotating cylinders that slowly crushed the cane. It is likely that the number of oxen farmers used to grind sugar cane varied with the size of the mill. One planter reported that he "worked his mill with three yoke of oxen at a time."16

\footnotetext{
${ }^{13}$ All the estimates and prices in this chapter and the dissertation are in the dollar values of the nineteenth century (i.e., the time of the transaction), unless otherwise indicated. The prices of the mills are found in the following sources: Annual Report, 1866, 29-30, Ibid., 1859, 15.

${ }^{14}$ Sitterson, Sugar Country, 160.

${ }^{15}$ This estimate is based on an account in the African Repository which stated that two steam mills and thirteen wooden mills cost $\$ 15,000$. AR, 1865,45 .

${ }^{16}$ Ibid., 1863, 312.
} 
Historian Richard Dunn noted that sugar cane farmers in the West Indies employed "half a dozen oxen or horses and several men" at a time. ${ }^{17}$

All the animals used for traction in Liberia (with the exception of the ones the ACS occasionally supplied) were acquired from the Liberian interior or more accurately, from "Mandingo Country" (i.e., Guinea). ${ }^{18}$ The two types of beasts of burden commonly brought from Guinea were horses and oxen. Given the dearth for these animals, prices often varied. Scion Harris, one of few farmers to utilize both horses and oxen, noted that the "cattle is cheap ... from six to seven dollars apiece ... The horse cost from forty to fifty \& sixty [dollars]."19 A sugar cane planter stated that "While in Bopora [Bopolo] I purchased a heifer for paid $\$ 15 \ldots$ Horse cost about $\$ 75$ or $\$ 150$ in goods. ${ }^{20}$ When the price of the animals is added to the other costs (e.g., the wooden mill, the kettles, the laborers and the construction of the sugar house), a planter would need at least $\$ 2,500$ to start a second-rate sugar manufacturing business. This was a hefty sum for the settlers, a large percentage of whom had never earned wages all of their lives.

Land, the other factor of production, was relatively easy to acquire until 1856 through the $1860 \mathrm{~s}$, when Liberians became preoccupied with sugar production. That obsession, which the Liberia Herald described as a "mania for sugar cane estates," led to the abrupt rise in the price for land. An article in the September 1859 edition of the Liberia Herald noted that the price of land along the St. Paul River (the center for sugar

\footnotetext{
${ }^{\Pi 7}$ Dunn, Sugar and Slaves, 192.

${ }^{18}$ See, for example, AR \& CJ, 1828, 14-15; AR, 1866, 340; Wiley, "Slaves No More," 235.

${ }^{19}$ Wiley, "Slaves No More," 235.

${ }^{20} \mathrm{AR}, 1866,340 . \mathrm{b}$
} 
production) had been steadily rising. The newspaper blamed the "mania for sugar estates" for the "rapid rise in the price of land suitable for cane." ${ }^{21}$ It concluded that "there are no lands immediately on the river that can be procured unless of exorbitantly high rates." 22

It appears that the price of land along the St. Paul continued to rise in the $1860 \mathrm{~s}$. According to the African Repository of 1864, an acre of "front tier" land on the St. Paul River cost " $\$ 25 . " 23$ Evidence discovered in a letter of 1859 suggests that the 1864 price was about 300 percent higher than it had been in 1859 . The letter was written by an immigrant called James Skipwith. In his correspondence, Skipwith proudly told his former master in the United States: "I have 10 acres of Land for which I Pade $\$ 6$ an Acre ... The land . . . is front land on the St. Paul River ... No better land has ever been found on James River [in Virginia]."24 Skipwith was so confident that he had made a good investment, he assured his erstwhile owner: "I believe that I shall make my Bread."25 Skipwith did not become prosperous or make his "bread" as he had so convincingly predicted: He died in 1861 just when some of his peers, who had bought land in the 1850s and planted sugar cane, began to make their "bread." 26

\footnotetext{
${ }^{9}$ Liberia Herald, 7 September 1859.

${ }^{22}$ Ibid.

${ }^{23} \mathrm{AR}, 1864,188$.

${ }^{24}$ Wiley, Slaves No More, 92.

${ }^{25} \mathrm{Ibid}$.

${ }^{26}$ Ibid., 98.
} 
The Sugar Region of Liberia: St. Paul River and its "Few Facilities"

From the beginning of sugar production in the 1840 s to the collapse of the industry in the 1880 s, the St. Paul River remained the only region in Liberia where sugar was manufactured for overseas trade. Although there were river basins and alluvial land in other parts of the country suitable for the cane, none of those regions were ever able to challenge the supremacy of the St. Paul River. In 1860, an observer stated the obvious when he explained why sugar cane was confined to the "vicinity of the St. Paul's river." At the time the observer noted that "the influence of a few facilities which our farmers in this region have enjoyed over their brethren of the other settlements, has given them an honorable vantage ground for the present." 27 The "few facilities" were the equipment for making sugar (e.g., mills and sugar houses).

The underlying reason, however, why farmers selected the St. Paul River region was its proximity to Monrovia, the commercial and administrative capital of Liberia. None of the sugar-producing region of the St. Paul was situated more than 20 miles from Monrovia where essential services such as overseas transportation and access the government services were provided. ${ }^{28}$ Moreover, the location of the St. Paul provided an opportunity to those settlers, who doubled as planters and politicians, to live on their plantations and still make the daily commute to Monrovia for work or vice versa.

Essentially then, Monrovia played the role of a central-place by "providing central goods"

${ }^{27}$ Ibid., 1860, 311.

${ }^{28}$ Transatlantic ships did make voyages to the Ports of Buchanan and Cape Palmas, but the vessels tended to disembark at Monrovia more frequently precisely because the latter offered a higher volume of trade and services. 
like shipping service to "complementary regions" such as the St. Paul River sugarproducing settlements. ${ }^{29}$

All the facilities for making sugar were located in about four or five of the approximately ten settlements of the St. Paul River during the era of sugar cane. The most prosperous sugar manufacturing settlements were Louisiana, White Plains, ClayAshland and the New York Settlement. Louisiana was established in about 1843. It was founded by former slaves of an American planter called John McDonogh from the southern state of Louisiana. ${ }^{30}$ White Plains, established in 1835 , was home to several sugar manufacturers. Clay-Ashland, originally called "Kentucky", was established in 1847 by immigrants from Kentucky in the United States. The name Clay-Ashland was later adopted in honor of Speaker Henry Clay (a founding member and President of the ACS) and his hometown, Ashland. Clay-Ashland would turn out to be a booming coffee settlement in the last quarter of the century. By 1863 , there were seven small sugar cane farmers in Kentucky, none of whom possessed a steam mill. ${ }^{31}$

New York, founded in 1852, was the wealthiest of all the sugar cane settlements. In a way, New York embodies the entire sugar cane era: the fortune and decline of New York was intertwined with the sugar cane industry. By 1852, sugar cane farming became the principal economic activity in the settlement. By the 1860 s, the settlement became Liberia's primary sugar producer. In 1863, the settlement accounted for the largest

\footnotetext{
${ }^{29}$ For a the discussion on the central-place theory, see, Walter Christaller, "Central Places in Southern Germany," trans., Carlisie W. Baskin, (Englewood Cliffs, NJ: Prentice-Hall, 1966) and Peter Haggett, "Geography: A Modern Synthesis (New York: Harper \& Row, n.d.), 363-397.

${ }^{30}$ See Wiley, "Slaves No More," 116-153.

${ }^{31} \mathrm{AR}, 1863,310-311$.
} 
number of sugar cane growers in the region of the St. Paul. Four New York producers, owned about 36 percent of all the sugar cane farms on the St. Paul by $1863 .^{32}$ New York also operated three of the four steam sugar cane mills that existed in Liberia by 1865 . The decline of the sugar cane era also resulted in the demise of the once prosperous New York Settlement. As the sugar era came to an end, the settlement was gradually abandoned. By end of the decade, nearly all the sugar cane farmers had deserted the settlement. The New York Settlement was eventually incorporated by Caldwell, its much older, nearby neighbor. The conspicuous advantage that the St. Paul held in sugar production did not prevent other riverine communities from aspiring to grow sugar cane and manufacture sugar. A potential sugar manufacturing region was located at the Junk River, about 35 miles southeast of Monrovia. The probability that the marshy land of the Junk River could become a rival to the St. Paul was noted by an observer who said that the region was "unsurpassed by any in Liberia for growing sugar cane." ${ }^{33}$ The Junk region was just as suitable for sugar cane as the St. Paul, and even though the residents cultivated sugar cane, they never became sugar producers. Hilary Teage's analogy, in the epigraph at the beginning of the chapter, that "however combustible the fuel, a little heat is necessary to create combustion," is particularly relevant to the case of the Junk region. In spite of its comparative advantage for growing sugar cane and the determination of the settlers to cultivate the cane, the Junk region did not have the "few facilities" or "a little heat" that made the settlements of the St. Paul the center of sugar manufacturing. (See Figure 4 for St. Paul River Settlements.)

\footnotetext{
${ }^{32}$ Ibid., 1863, 310-311.

${ }^{33}$ Liberia Christian Advocate Newspaper, quoted in AR, 1860, 311.
} 


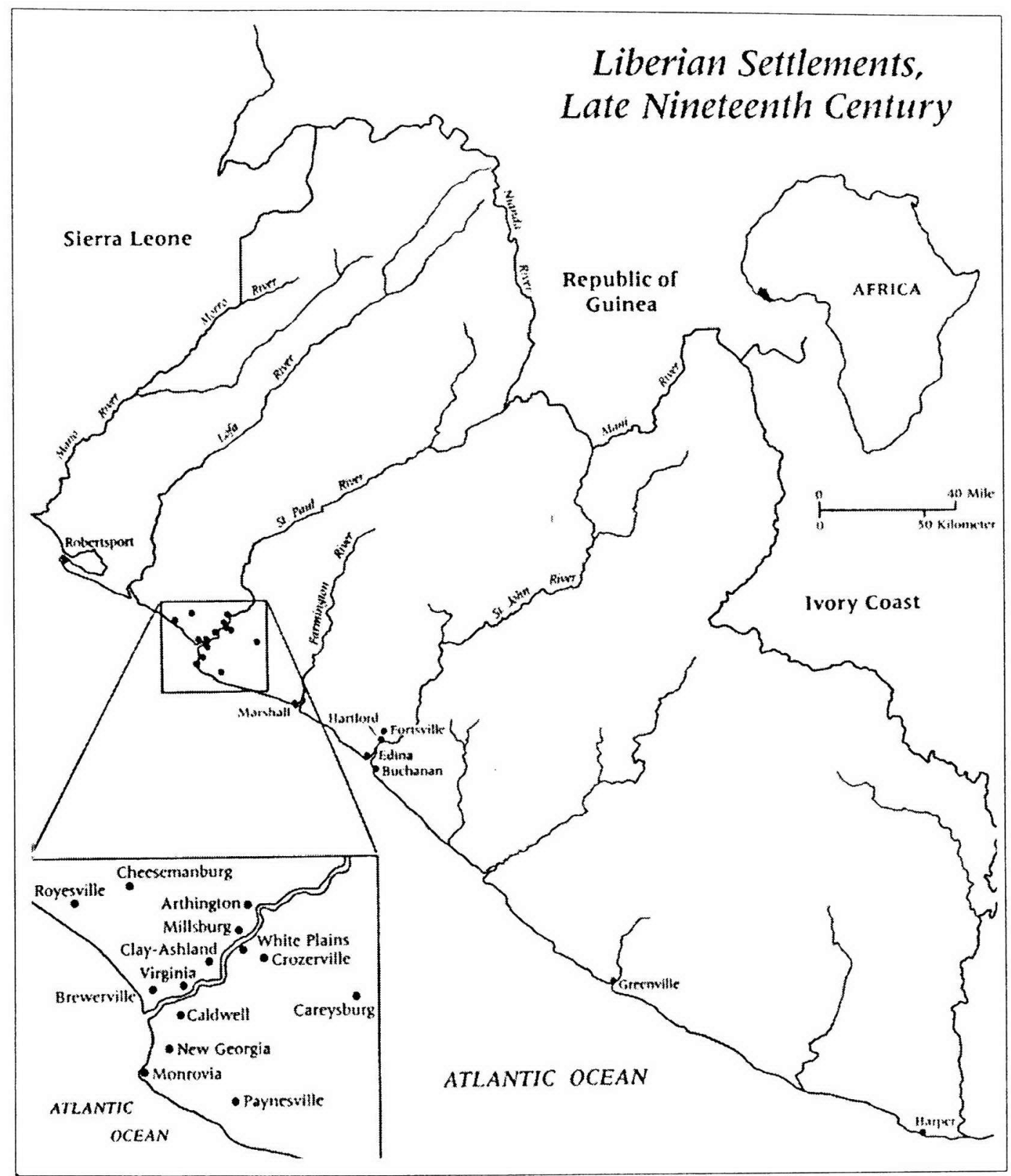

Figure 4. Map of Liberia with St. Paul River Settlements. (Reprinted by permission of Brockton Art Museum, Holsoe and Herman, 1988). 
Another region with the potential for matching or overtaking the St. Paul in the production of sugar, was Maryland, the easternmost coastal territory of Liberia. In fact, the Marylanders were probably the first to manufacture cane sugar in Liberia. Maryland unique political history kept the story of its advances in sugar manufacturing separate from the rest of Liberia. The colony was established in 1834 by the independent colonization society of the State of Maryland in the United States. Like Liberia, Maryland was founded as a refuge for the growing population of former slaves who were perceived as a threat to the stability of the institution of slavery in that state. Until 1857 , the Maryland Colonization Society governed its settlement on the Atlantic coast independently. In that year, the quasi-independent State of Maryland in Liberia agreed to be annexed by the Republic of Liberia and became Maryland County. The city of Harper is the capital. ${ }^{34}$

Maryland was reported to be just as favorable for growing sugar cane as the St. Paul and Junk region. As early as the 1840s, several Maryland settlers began to cultivate sugar cane on the banks of the Cavalla River, the current boundary between Liberia and the Ivory Coast. They observed that the alluvial lowland was ideal for sugar cane. In the 1850 s, one visitor recorded the following observations about sugar cane farming in Maryland: "Sugar-cane . . . thrives well here, as it does in most places on the West Coast. It is generally twelve feet in length, averaging seven or eight inches in the joint, and two inches in diameter." 35 An excerpt from the 1842 Annual Meeting of the Maryland State

\footnotetext{
${ }^{34}$ Campbell, Maryland in Africa.

${ }^{35}$ Charles W. Thomas, Adventures and Observations on the West Coast of Africa, and Its Islands (Mobile: John F. Early, 1860), 186.
} 
Colonization Society contained statements on the progress of agriculture in the settlement. On sugar cane, the Board of Managers reported: "The sugar-cane has succeeded well; and with the aid of a mill built in the Colony, several barrels of sirup were manufactured during the past year. ${ }^{36}$ A second report of sugar-making is found in the 1866 edition of the Cavalla Messenger, a local newspaper in Maryland. The story lauded the efforts of several men for making sugar: "Mr. J. W. Ashton ... on the Cavalla is due the credit of making the first, [syrup] which was of an excellent quality" at Cape Palmas." ${ }^{37}$ Furthermore, the narrative continued: "We should import no more foreign syrup, even though the Liberian Legislature had imposed no duty, for we like the domestic better." Besides Ashton, there were at least two other producers of sugar, all of whom reportedly used sugar cane mills that were constructed locally. ${ }^{38}$ There is no information on how the mills were constructed or powered. They were probably driven by humans or animals or both; several reports indicate that oxen were used as draft animals in Cape Palmas. ${ }^{39}$

Notwithstanding their obvious ingenuity and optimism, Marylanders did not become the prosperous sugar producers they had anticipated. The locally manufactured mills were hardly capable of producing sufficient quantity of sugar for local consumption or able to compete with the advanced steam sugar cane mills of the St. Paul. One sugar manufacturer from the St. Paul mentioned in a 1863 report that a portion of "twenty

\footnotetext{
${ }^{36}$ Maryland Colonization Society, Feb. 3, 1842, quoted in AR \& CJ, 1842, 76-78.

${ }^{37}$ The Cavalla Messenger Newspaper, quoted in AR, 1866, 13. Cape Palmas is the principal settlement. ${ }^{38}$ Ibid.

${ }^{39}$ For example, see, AR, 1890, 89.
} 
thousand pounds" of sugar was shipped from St. Paul "to our settlements along the coast." ${ }^{40}$ Maryland was perhaps one of the recipients of the sugar from the St. Paul. Besides the Junk region and Maryland, there were other marshy lands on the Liberia coast that were ideal for sugar cane cultivation. Another example of a potential sugar cane region was the swampy banks of the Sinoe River in Sinoe County. In 1838 a new immigrant in Greenville (the principal town and present capital) informed an acquaintance in the United States (probably his former owner) that "sugar cane grows very well here."41 But there is no evidence that sugar was ever manufactured in the settlement of Greenville or Sinoe County for that matter.

The inability of Sinoe and the other regions to produce sugar was directly related to the lack of capital and equipment. Although the Junk region, Sinoe and Maryland were located farther away from Monrovia (the central place), each of the three areas nevertheless had access to a seaport. As a result, manufactured sugar from these locations could have been exported without passage through the port of Monrovia. Therefore, in the end it was the absence of "few facilities," that is mills and sugar houses in these potential sugar-manufacturing regions, that prevented them from manufacturing sugar for commercial transactions overseas.

\section{"Intelligent Immigrations, A Little Heap of Money"}

The prerequisites for setting up sugar establishments (i.e., labor, capital, land and entrepreneurship) were beyond the means of the average immigrant. Just before the end

\footnotetext{
${ }^{40} \mathrm{AR}, 1863,28$.

${ }^{41} \mathrm{AR} \& \mathrm{CJ}, 1838,79$.
} 
of the first half of the century, two persons had publicly predicted that whenever capital became available to farmers in Liberia, commercial agriculture would prosper. Ralph Randolph Gurley, the Corresponding Secretary of the ACS in Washington, D.C., was one of those who made the prediction. Gurley was among the very few number of officials in Washington who were familiar with conditions in Liberia. He first visited Liberia in 1824 to resolve a bitter dispute between the settlers and the ACS-appointed leadership. It was during his second visit in 1849 , which was under the directive of the United States Government, that Gurley made the projection: "It may be confidently predicted, that, whenever adequate capital, skill, and machinery shall be introduced, the culture of rice, cotton, the sugar cane and coffee, will prove as successful and profitable as in any region of the world." 42

The other person that predicted that the success of commercial agriculture was contingent upon the availability of capital, was Hilary Teage. Teage, it can be recalled, was a wealthy merchant. He was the Thomas Jefferson of Liberia, having written the Declaration of Independence in 1847. In 1851 when Teage made his prediction (i.e., the epigraph that opens this chapter) he was one of the elders of the Americo-Liberian community, having arrived in Liberia more than a quarter century earlier. ${ }^{43}$ For many years he served as editor of the Liberia Herald, the oldest newspaper in Liberia. From

\footnotetext{
${ }^{42}$ Annual Report, 1856, 30.

${ }^{43}$ According to The Census, Teage emigrated in 1821 . In the $A R$ the year 1825 is given as the date of his emigration. A possible explanation for the mixed up is that Teage may have gone to Sierra Leone in 1821 to join the first group of immigrants. He probably left Sierra Leone for Liberia in 1825, about three years after the Colony was established. See "The Census" and AR, 1853, 302.
} 
that vantage point, combined with his long experience in Liberia, Teage became closely aware of the problems of commercial agriculture.

Teage was aware of the difficulties that farmers encountered, yet, he had seen some progress in coffee and sugar cane farming. For example, by 1851 there were more coffee trees in Liberia any previous period. ${ }^{44}$ Teage was also aware of the advances that were made in sugar cane farming. In 1851, the two sugar producers I mentioned in Chapter II, Abraham Blackledge and A. T. Russell, were manufacturing sugar for local sale. ${ }^{45}$ But the progress in sugar manufacturing was stymied by the lack of machinery. One visitor to Blackledge's sugar operation wrote the Treasurer of the ACS in 1851 and inquired:

Can't some Colonization friends raise a good sum of money (say $\$ 25,000$ ) which might be loaned out to the different enterprising farmers ... as Mr. B. [Blackledge]. . . . His mill is a simple one, and is moved by hand power." ${ }^{46}$

The $\$ 25,000$ could have bought a number of the advanced steam engine sugar cane mills that were already being used by sugar manufacturers in the United States.

Soon after 1850 , the situation began to change for the better. In fact, although Hilary Teage died in 1853, he lived long enough to witness the arrival of his "intelligent immigrations" and "a little heap of money" which he had predicted would spur commercial agriculture. The immigrants arrived in Liberia from 1849 through the $1850 \mathrm{~s}$. They immediately invested in the fledgling sugar industry. Not only did the newcomers

\footnotetext{
${ }^{44}$ In 1851 A. T. Russell owned 8,000 coffee trees which surpassed the 6,345 coffee trees enumerated in the Colony in 1843 . AR, 1852, 47;

${ }^{45} \mathrm{AR}, 1851,227$; Ibid., 1852, 47, 239.

${ }^{46}$ Ibid., 1852, 227.
} 
generate the capital (i.e., "a little heap of money") but they were also entrepreneurs. Due to their resourcefulness and determination to succeed, they-along with other progressive planters--were dubbed the "enterprising farmers." I have reconstructed their individual roles in the production of sugar from the available data in the archival and secondary sources.

\section{The Enterprising Farmers}

I stated previously that in 1859 , the Liberia Herald described the growing interest that Liberians manifested in sugar cane as a "mania for sugar cane estates." This new obsession with sugar cane was stimulated by the enterprising farmers. From the limited sources, I was able to identify a dozen enterprising farmers. However, I chose nine of them because of their obvious impact on the sugar industry (Table 3.1.) All of the enterprising farmers shared some common traits. Aside from the fact that they arrived in Liberia about the same period, half of the enterprising farmers were free at the time of emigration. And more than 50 percent of them could read and write.

Each of the enterprising farmers was a combination farmer-sugar manufacturer. This means that they cultivated sugar cane and manufactured sugar. The manufacturing process was conducted from on the plantation. Most of the plantations operated as a complete production unit. It contained the raw material for making sugar (i.e., the cane), the mill, the sugar house, the planter's home and probably living quarters for some workers. The planters maintained a regular, hired workforce, but released some of the laborers at the end of the sugar-making cycle. As a rule, the mill and sugar house were constructed side by side so workers could expeditiously transport the newly extracted 


\begin{tabular}{llll}
\hline Name & $\begin{array}{l}\text { Status at time of } \\
\text { Emigration }\end{array}$ & Education & $\begin{array}{l}\text { Date of } \\
\text { Emigration }\end{array}$ \\
\hline John R. Jordan $^{\mathrm{a}}$ & Emancipated & Literate & 1852 \\
Garret Cooper $^{\mathrm{b}}$ & Not Available $^{*}$ & Not Available & Not Available \\
William Anderson & Free & Literate & 1852 \\
Jesse Sharp & Unknown & Literate & 1849 \\
L. L. Lloyd & Unknown & Unknown & Unknown \\
Augustus Washington & Free & Literate & 1853 \\
William Roe & Free & Literate & 1853 \\
Thomas Howland & Free & Unknown & 1857 \\
M. T. Decoursey & Emancipated & Literate & 1851 \\
\hline
\end{tabular}

Source: Compiled from the following: Robert T. Brown, Immigrants To Liberia, 1843 to 1865; Wilson Jeremiah Moses, ed. Liberian Dreams: Back-to-Africa Narratives from the I850s; AR \& CJ, 1850, 235, AR 1863, 27-29; 310-311;

${ }^{*}$ Not Available $=$ No information found in the archives

${ }^{\text {a }}$ Evidence suggests individual died in the $1850 \mathrm{~s}$

${ }^{\mathrm{b}}$ Garret Cooper and two sons, William and James, operated the farm.

'It is very probable that Lloyd was literate. There is no "L. L." Lloyd on the roll. But seven persons with the surnames of "Lloyd" are recorded on the list. All of them traveled to Liberia in the same vessel, on the same date and from the same state. Five of the seven "Lloyds" are literate. The illiterate ones are two children who are one and four years of age. L. L. Lloyd's name may have been mistakenly omitted or incorrectly written on the roster, due to the "record keeping" of the ACS which Brown described as "haphazard." (See p. iii in Brown, Immigrants To Liberia.)

cane juice to the sugar house where it was boiled until it was crystalized into sugar. ${ }^{47}$

Sugar cane fields were located as close to the mills as possible, so as to minimize the inconvenience in transporting the bulky sugar cane stalks and lower cost. The size of the sugar cane fields varied. In 1863, the largest cane field covered 35 acres and the smallest,

\footnotetext{
${ }^{47}$ Dunn noted that Sugar producers in the West Indies had a separate house for curing the sugar after it was boiled. Dunn, Sugar and Slaves, 195. The evidence seems to demonstrate that Liberian planters cured the sugar in the sugar house.
} 
3 acres. ${ }^{48}$ This was comparatively very small, considering that in the New World it was not unusual for one planter to cultivate 80 acres of cane in a single season. ${ }^{49}$ The bulk of the Liberian manufactured sugar was packaged and transported to Monrovia in small boats for shipment overseas.

John B. Jordan: The Pioneer of Steam Sugar Cane Mill?

Jordan may have been the first enterprising farmer to purchase a steam sugar cane mill. An advertisement in the Liberia Herald of 1856 announced that Jordan had "obtained a steam sugar mill for making sugar." ${ }^{0}$ A brief description of Jordan's operation is found in the Annual Report of 1857. The account was written by John Seys, a white Trinidadian Methodist missionary who returned to Liberia after being absent for about fifteen years. Seys noted that Jordan-along with "others"- owned "acres upon acres of cane." The quality of their sugar cane, he asserted, surpassed that in all of the "fifteen West India Islands." ${ }^{51}$ Seys also mentioned that at Jordan's farm, called Bellevue, "a steam sugar cane mill is in operation ... making sugar and syrup." 52 Jordan may have died shortly after he bought the mill for his name disappeared from latter

\footnotetext{
${ }^{48} \mathrm{AR}, 1863,310-311$. Individual holdings did increase through the sixties and seventies.

${ }^{49}$ Dunn, Sugar and Slaves, 189.

${ }^{50}$ Liberia Herald, 6 August 1856.

${ }^{51}$ Annual Report, 1857, 15.

${ }^{52}$ Ibid. Many Liberians considered Seys, who was a white Trinidadian, knowledgeable about sugar cane culture. Shortly after his return, some of the farmers asked him for advice on growing sugar cane. Seys later prepared "a little treatise on the cultivation of the sugar-cane and the manufacture of sugar" for the farmers. Annual Report, 1857, 15.
} 
accounts. He is also conspicuously missing from the list of farmers published in $1863 .^{53}$ It is uncertain whether a Mrs. M. M. Jordan, one of five women on the roll, is the widow of John B. Jordan. The "others" that Seys referred to are Abraham Blackledge, the Coopers (that is, Garret Cooper and sons), Jacob M. Richardson and Jesse Sharp. Blackledge later gave up sugar cane farming and concentrated on coffee. He is included on the roster of 1863 as a coffee farmer.

\section{Garret Cooper and Sons: A Family Affair}

Garret Cooper and two sons, William and James, operated the only major family sugar manufacturing business in Liberia. The Coopers and Jacob Richardson may have purchased the next two steam sugar cane mills. In 1856 Garret Cooper received a steam sugar mill through credit arranged on his behalf by H. M. Schieffelin (an American supporter of the ACS) and "other Christian philanthropists of New York." 54

The Coopers' farm, called Coopersville, was located in Louisiana. In 1863, the Coopers owned 35 acres of sugar cane, representing the largest acreage under cultivation. Coopersville contained approximately 17 percent of the total 209 acres under sugar cane cultivation at the time ${ }^{55}$. An account of the Coopers' sugar operation is found in an article entitled "A Day on the St. Paul's River." The story, narrated by two men, was first published in the Liberia Herald Newspaper and then reprinted in the African Repository in 1865 .

\footnotetext{
${ }^{53} \mathrm{AR}, 1863,310-311$.

${ }^{54}$ Ibid.

${ }^{55} \mathrm{AR}, 1863,310-311$.
} 
The men toured the sugar facility at Coopersville and were obviously impressed. They visited the mill and observed that "the grinding had ceased, but the mill had done a good day's job. ...". In the sugar house, the men explained that, “. . the kettles were full and boiling." They concluded their account with the following description: "One of the most interesting sights at Coopersville, was the fine oxen bringing in cart loads of cane to the mill. The field of cane stretched far and wide." 56

Garret Cooper and his sons became prosperous businessmen. An indication of the Coopers' fortune was reported in the 1865 narrative: "Mr. Garret Cooper had erected a fine brick house since our last visit, and William Cooper had finished and was furnishing his new house, into which, (fortune being propitious), rumor says he will soon take a new wife." ${ }^{, 7}$ Additional proof of the prosperity of the Coopers' was published in a local newspaper, The True Whig, in 1869. The paper carried a publication called the Liberian Advertisements that looks like a "Who's Who" in the Liberian farming community. It included all the prominent farmers in Liberia. The Coopers were included in the advertisement as "planters, and manufacturers of sugar." 58

\section{William Anderson: The Heir Apparent}

Anderson's rise to prominence in the sugar business was made possible through his relationship to Jacob Richardson. Richardson was probably the owner of the largest and most expensive steam sugar mill in Liberia in the 1850s. Richardson's bought his

\footnotetext{
${ }^{56}$ Liberia Herald, (n.d.), quoted in AR, 1865, 139.

${ }^{57}$ Ibid. The wealthy class built their homes with stones or bricks, while the poor used woods and bamboos.

${ }^{58}$ The True Whig, quoted in AR, 1869, 184-185.
} 
steam mill through credit made possible by the New York Colonization Society. ${ }^{59}$ The ACS reported in 1859 that Richardson's steam mill was larger that the Coopers' and cost "over $\$ 6,000 . "{ }^{\prime 60}$ Unfortunately, Richardson did not live to receive the mill because he died before the prized machinery was unloaded in Liberia. ${ }^{61}$ Notwithstanding, his farm in the New York Settlement called Gandilla eventually became a major center of sugar manufacturing in Liberia. ${ }^{62}$ William Spencer Anderson, nephew of the deceased, was the man credited with managing the farm. He inherited Richardson's mill and the sugar cane estate. Anderson was born of free parents in Wilmington, Delaware and emigrated within about a month after Richardson left the United States. ${ }^{63}$ It is not clear whether Anderson, who was about twenty-five years old when he inherited the estate, had been a sugar cane farmer prior to his uncle's death.

Throughout the 1860s Anderson expanded the sugar cane operations. In 1863 he told the editor of the Liberia Herald that he generally hired seventy-five laborers on his farm "during crop time" and released thirty of them afterward. ${ }^{64}$ Anderson also informed the editor that one of his employees was a "sugar-maker from the West Indies . . .one who has acted in the capacity of head boiler-man in the Islands." ${ }^{\circ 5}$ Anderson was an ${ }^{59}$ Annual Report, 1859, 15.

${ }^{60}$ Ibid.

${ }^{61}$ Ibid.; AR, 1857, 162; Wiley, Slaves No More, 83.

${ }^{62}$ Richardson explained that the name was derived from a tree found on his land, "... native tree of that name ... something like ... oak." AR, 1855, 278.

${ }^{63} \mathrm{AR}, 1862,62$.

${ }^{64} \mathrm{AR}, 1863$, 28. Crop time referred to the period when the sugar cane is harvested, transported to the mill to be crushed and processed into sugar.

${ }^{65} \mathrm{AR}, 1859,302$. 
efficient businessman, who sold sugar at home and abroad. In 1862, the Liberia Herald published an advertisement for Anderson's sugar. His product was described as "a superior article of steam Refined Brown Sugar," and he invited the public to "examine samples" of his sugar at two local "places of business." States and to some British West African colonies. ${ }^{67}$ The ACS cited a section from The Republican, a local newspaper, about sugar production and sale in 1872. Anderson and Jesse Sharp were referred to as "our principal planters." Both men, the article continued, "have gone to the United States on business connected with an extension of their trade." The paper noted that Anderson shipped "fifty thousands pounds" of sugar on a ship called the Thomas Pope. ${ }^{6}$

By 1875 , Anderson's prosperous sugar cane business appeared to have suddenly collapsed. He probably did not export sugar after 1875. A story in the African Repository suggests that Anderson's fortune had begun to decline several years earlier. Clues from the story indicate that the collapse of his business may have been unrelated to the general economic circumstances that would eventually result in the demise of all the other sugar manufacturing operations in the nineteenth century. According to the account

Some six thousand pounds of sugar are to be shipped ... by Mr. Sharp shortly. Mr. Cooper, and Mr. Roes . . . are making fair crops; and last, but not least, Mr. W. Anderson, although recent embarrassments precluded him from giving his wonted attention to his estate, still bids fair, we understand, to make it furnish the market with a credible return in sugar. ${ }^{69}$

\footnotetext{
${ }^{66}$ Liberia Herald, 18 February 1862.

${ }^{67} \mathrm{AR}, 1863,28$.

${ }^{68}$ The Republican, 10 June 1871, quoted in Annual Report, 1871, 15.

${ }^{69} \mathrm{AR}, 1872,345$.
} 
Anderson's "recent embarrassment" may have been related to the Roye episode in Liberian history. Besides being a successful farmer, Anderson was also Speaker of the House of Representative during the turbulent years of President Edward J. Roye. Probably because he was dark-skinned, Roye's ascendancy to the presidency in 1870 heightened the growing rivalry between the dark-skinned and mulatto settlers in Liberia. His presidency was marred by other controversies, including the loan of 1871 that his administration was accused of embezzling and the presidential term of office. The embattled Roye was eventually deposed from power in 1871 by a coup led by his adversaries in the mulatto-dominated Republican Party. He died in prison under mysterious circumstances. ${ }^{70}$ In the aftermath of the Roye episode, many prominent members of the President Roye's True Whig Party, including some close friends, were arrested and publicly humiliated. ${ }^{71}$ Anderson, one of those that negotiated for the controversial London loan, lost his position as Speaker of the House. ${ }^{72}$ A review of the list of dignitaries or "August gathering" that attended the inauguration of Roye's successor, Joseph J. Roberts, revealed that Anderson was absent. ${ }^{73}$ Perhaps someday, the evidence will reveal the exact nature of the "embarrassments" that kept Anderson away

\footnotetext{
${ }^{70}$ According to the official report Roye escaped from prison and was drowned while attempting to swim to a "foreign boat" with a "bag of gold" tied around his waist. Ibid., 1872, 255. Edward Blyden, the distinguished Liberian intellectual and confidant of Roye, who narrowly escaped death during the chaos, later explained that Roye was "shot and killed" when he escaped from prison. Blyden to Coppinger, 22 October, 1887, cited in Hollis Lynch, Edward Wilmot Blyden, 51.

${ }^{71}$ Lynch, Edward Wilmot Blyden, 50-53

${ }^{72} \mathrm{AR}, 1872,271$.

${ }^{73}$ Ibid., 270-273.
} 
from his thriving sugar cane business. In any event, his financial problems may have been more related to politics rather than to adverse market forces.

\section{Jesse Sharp: “An African Sugar Planter"}

Jesse Sharp was perhaps the last prominent farmer to acquire a sugar cane mill in the 1850s. About two decades later, Sharp was widely acknowledged as one of the wealthiest men in Liberia. The story of Sharp's success (like all the enterprising farmers) shows determination and hard work. Earlier in his career, Sharp could not afford to buy the much-preferred steam engine mill so he purchased the cheaper wooden mill. When the mill proved inadequate, Sharp began to make plans to acquire the more advanced steam engine mill. Sharp sent a letter to a Mr. C. Swan in the United States in 1863 expressing his desire to procure a steam mill: "I am trying to remit funds to purchase a steam-engine to attach to my sugar mill; and if I succeed . . . I shall increase my crop of cane."74 Later that same year Sharp informed an acquaintance in the United States: "The last year I hired one of the mills that was bought by the Government, and in turn hired out mine, which was too small for my use. "75 Sharp purchased the steam mill in 1863 and went on to become a prosperous planter. The ACS published a story on Sharp's accomplishment in 1866 and recalled how Sharp, who the writer called "An African Sugar Planter," overcame the odds to become successful:

Mr. Jesse Sharp, who was a house-painter at Charleston, S. C., removed to Africa in 1852; had a few acres of cane on the St. Paul's river, was aided in getting a Mill by a judicious Vice President of the Society ... He has steadily added to his cane each year. In 1863, a much larger mill, with improved machinery, was advanced

\footnotetext{
${ }^{74} \mathrm{AR}, 1863,310$.

${ }^{75}$ Ibid., 312.
} 
to him by two active friends of our cause, costing about two thousand dollars. This he paid for, in $1864 \ldots$ and a few months ago he had some two thousand dollars in New York for the purchase of goods . . ."76

Sharp continued to produce sugar in the 1870 s. By the next decade, his business, which was located in New York, had disappeared like all the others.

\section{L. Lloyd: Inefficient Entrepreneur or Victim of Unfortunate Circumstances?}

The acquisition of a steam sugar cane mill by L. L. Lloyd in 1864 , could not have come at a better time for the sugar-manufacturing industry. By the beginning of the 1860 s, the "mania for sugar estates" had created renewed demand for additional mills. Accordingly in 1862, President Stephen Benson instructed his "Secretary of the Treasury to order from the United States a number of Sugar Mills and their fixtures" to meet the growing demand of farmers. ${ }^{77}$ The government-supplied mills were inadequate because

two years later, three of the enterprising farmers imported three steam mills. ${ }^{78}$ L. L. Lloyd was the owner of one of the new steam mills. His mill, a 35-horse power engine, generated considerable attention because it was reportedly "twice as large as any in Liberia."79

Lloyd owned one of the largest sugar cane farms in the country at the time he bought his steam mill. A year before he acquired the mill, Lloyd was the third largest sugar cane cultivator, with 25 acres. His 25-acre sugar cane farm in New York, was

\footnotetext{
${ }^{70}$ Annual Report, 1866, 15-16. The ACS must have erred about the date of Sharp's arrival in Liberia. Sharp indicated in a letter that he arrived in Liberia on 1849. On April 22, 1850, he wrote, "Since I have been here in Liberia, which is about seven months." AR \&CJ, 1850, 235.

${ }^{77} \mathrm{AR}, 1862,86$.

${ }^{78}$ Annual Report, 1864, 187-188.

${ }^{79}$ Ibid., AR, 1867, 216.
} 
larger than that of the "African Sugar Planter" and equaled approximately 12 percent of the reportedly 209 acres under sugar cane cultivation in $1863 .^{80}$ Like Jordan, Lloyd faded from the narrative not too long after he acquired the mill. Another planter rented his celebrated steam mill.

There is no clear explanation for Lloyd's disappearance. It seems that Lloyd, or whosoever operated the mill when it was leased, could not profitably manage the expensive steam mill. This conclusion is based on two pieces of evidence gleaned from the archives. The African Repository of 1864 carried the following story soon after Lloyd received the steam mill:

L. L. Lloyd arrived here ... brought a steam sugar cane mill ... His mill is going up; and at the same time he has informed all the small farmers on the river to plant as much as they can, as he proposes to purchase all their cane ... By carrying out his plan, Mr. Lloyd will be enabled to turn his whole attention to the manufacture of sugar; and soon purchase enough cane to keep his mill in operation. ..." ${ }^{81}$

Lloyd's plan not to grow his own sugar cane was revolutionary because each of the enterprising farmers cultivated his own sugar cane field. In fact, this has usually been the case for sugar manufacturers in other areas, including the West Indies and the United States. ${ }^{82}$ By growing their own cane, the manufacturers were assured of a regular supply of the raw material for making sugar. Without a cane farm, Lloyd would have had to rely on outsiders (i.e., the "small farmers") for the sugar cane to make sugar. If the small farmers were unable to produce the quantity of cane necessary to keep the huge mill

\footnotetext{
${ }^{80} \mathrm{AR}, 1863,310-311$.

${ }^{81} \mathrm{AR}, 1864,187-188$.

${ }^{82}$ See, Sitterson, Sugar Cane Country; Dunn, Sugar and Slaves.
} 
operating profitably, renting the mill to someone else may have been the logical alternative.

The second hint about what possibly happened to Lloyd's mill is also found in the African Repository. About a year after Lloyd's unusual decision not to grow his own sugar cane, someone made an observation which was probably a precursor to what eventually befell the 35-horse power steam mill. The observer compared Lloyds' sugar output with his peers and drew the following conclusion:

Four steam sugar cane mills now operate along the river, the most extensive of which belongs to L. L. Lloyd, Esq., of 35-horse power. This gentleman operates quite extensively, employing from fifty to sixty hands on his sugar farm, still he does not carry on as large a business in that line as some of his neighbors. It is said that Mr. Sharp manufactured about 60,000 pounds of sugar last season. This season he has a prospect of doubling the amount. Others operate equally extensively. ${ }^{83}$

The statement raises another alternative explanation for Lloyd's disappearance and the lease of the mill. Lloyd may not have been the efficient entrepreneur that Sharp and the other more successful planters were, and as a result, his business faltered. It is also very likely that Lloyd died after he obtained the mill, since the statement above is probably one of the last references to his business. This last interpretation is highly plausible when one considers that mortality was unusually high in Liberia and Lloyd dropped from the record suddenly. Instant death was common in the malarial environment of Liberia and the sugar cane planters had their share of unexpected departures (e.g., Jacob Richardson and John Jordan).

${ }^{83} \mathrm{AR}, 1865,234$. 
Augustus Washington: The Man With "Scores of Irons in the Fire."

Augustus Washington, the man who rented Lloyd's "celebrated mill," was very likely the most resourceful of all the enterprising sugar cane farmers. Prior to his relocation to Liberia in 1853 , Washington had been a teacher in the United States and is reported to have "studied informally for two years at Dartmouth College." He was a successful daguerreotyper in Hartford, Connecticut, a career that he would continue to pursuit in Liberia. Washington was quite active in the emergent African American politics of black nationalism that blossomed by the mid-century in the United States. He was among the large majority of black leaders who condemned the ACS and its Liberian colonization scheme. Washington advocated, instead, for a separate state for "AfricAmericans more congenial for their feelings and prejudice than Liberia." ${ }^{84}$ Unsuccessful in his effort to find a home for black Americans in the New World and haunted by escalating racial prejudice in the United States, Washington explained that he embraced the "little Republic of Afric-Americans on the Western coast." 85 He emigrated to Liberia with his family in 1853 . According to Washington, he reached Liberia with probably $\$ 1,000$ in cash, merchandise and photographic equipment. ${ }^{86}$

About two decades after his arrival in Liberia, Washington became one of the most resourceful and prosperous settlers in Liberia. He was a sugar manufacturer, a politician, and editor and proprietor of the New Era Newspaper, just to name some of his accomplishments. In 1873, when Edward Wilmot Blyden visited Washington's

\footnotetext{
${ }^{84}$ Moses, Liberian Dreams, 181-185.

${ }^{85}$ Ibid., 185.

${ }^{86}$ Ibid., 182.
} 
plantation called "Deerford," in White Plains, he was impressed with his host's

ebullience and referred to the former black nationalist as the man with "scores of irons in the fire." 87

Sugar cane farming was probably Washington's principal "iron." Washington recalled that his early years in Liberia were marked by hardship and diligent toil:

After being here a year or more, I became convinced that the true interest of Liberia consisted in the development of her agricultural ... resources. Then I had no capital, no mill, no cattle, no horses. . . But I continued to plod along, acting as merchant at Monrovia, farmer on the St. Paul's and artist at Sierra Leone, the Gambia and Senegal. ${ }^{88}$

Another independent account by ex-president Roberts, which was published in

1859 , is further proof of Washington's resolve to succeed as a farmer:

Bright and early ... we were all assembled at the depot, Augustus Washington's, - and here again we found encouraging evidences of agricultural enterprise. On reaching the landing-place, a large boat, filled with superb sugar canes, was starting for Anderson's mill; and in the field, Mr. Washington had employed a number of hands, some cutting, some planting, and others carrying canes to the landing. ${ }^{89}$

By the next decade Washington had begun to reap substantial financial returns

from his sugar cane farm. He declared triumphantly in 1864: "I am six thousand dollars better than I ever was in the States." ${ }^{90}$ This was about the same time that he bought his steam mill. But when the new mill was unable to crush his increasing volume of sugar cane expeditiously, Washington rented the "celebrated Lloyd mill."

\footnotetext{
${ }^{59} \mathrm{AR}, 1873,374$.

${ }^{88}$ Ibid., 223.

${ }^{89} \mathrm{AR}, 1859,248$.

${ }^{90}$ Moses, Liberian Dreams, 222.

${ }^{91} \mathrm{AR}, 1867,172$.
} 
Washington was regularly manufacturing and exporting sugar. In March of that year a contemporary wrote that Washington was expected to "ship to America or England ... over one hundred thousand pounds of sugar, and syrup and molasses in proportion." 92 That same year, Washington revealed that since the beginning of the decade he had sold "from thirty to sixty thousand pounds of sugar in Sierra Leone and on the coast." Some of the sugar, according to Washington, was manufactured by others. ${ }^{93}$ About three years later the African Repository published a letter about the sugar industry in Liberia. Of Washington's operation, the paper maintained that

He has over 1,000 acres of land; raises a large amount of sugar and other products; gives employment to a large number of poor men, emigrants and natives; has a fine sugar mill on his own premise, which he has lately fixed after the most approved style of the British West Indies, but which is too small for the immense amount of cane now ready for grinding on his farm. He has, therefore, recently leased, for a time, the large steam-mill formerly owned by L. L. Lloyd. ${ }^{94}$

At the time of Washington's death in 1875 , he was not only among the top four or five sugar manufacturers in Liberia, but he was Speaker of the House of Representatives, the position previously held by Anderson. ${ }^{95}$ Washington and Anderson were the only two sugar cane farmers to ascend to such influential post in the government. An obvious question is whether the political careers of Washington and Anderson contributed to the success of their sugar business. There is no direct evidence that they or any of the enterprising farmers used political influence to promote their businesses or gain special

\footnotetext{
${ }^{92}$ Ibid.

${ }^{93}$ Ibid., 1868, 61-62.

${ }^{94}$ Ibid., 1867, 172.

${ }^{95}$ Ibid., 1874, (page number illegible); Ibid., 1875, 118.
} 
favors or advantages. The evidence that Washington and Anderson began their career as farmer is quite strong. Still, Amos Sawyer's observation that many of the wealthy merchants, who were officials of government did not pay any taxes, suggests that using political influence to gain advantages in businesses was not very unusual. ${ }^{96}$ Besides tax evasion, Washington and Anderson could have used (or more precisely misused) their offices in the recruitment of labor. There is proof, for example, that the AmericoLiberians exploited the indigenous population, mainly by not paying them for work performed or underpaying them. ${ }^{97}$ Nevertheless, there is no proof that Washington or Anderson abused their offices in this manner, even though the men were noted for hiring “a large number of poor men," including "natives."

William Roe, Thomas Howland and M. T. Decoursey: Making Sugar Without a Steam Mill

The inclusion of William Roe, Thomas Howland and M.T. Decoursey onto the group of enterprising farmers is intended primarily to demonstrate that some planters without the much preferred steam mills, still managed to manufacture sugar. None of the three men appears to own a steam mill prior to $1866 .{ }^{99}$ Roe is mentioned as the proprietor of a steam mill in 1869 . It is very unlikely that Howland ever bought a steam mill. And

\footnotetext{
${ }^{96}$ Amos Sawyer, The Emergency of Autocracy, 162.

${ }^{97}$ For example see, George E. Brooks, “A. A. Adee's Journal of a Visit to Liberia in 1827," Liberian Studies Journal 1, 1 (1968), 60; Moses, Liberian Dreams, 87-178.

${ }^{98} \mathrm{AR}, 1867,172 ; \mathrm{AR}, 1863,28$.

${ }^{99}$ Between 1856 and 1866 , six steam mills were purchased although a 1866 report indicated that only four mills were in operation. The six mills were purchased by Jordan, the Coopers, Anderson (i.e., Jacob Richardson), Sharp, Washington and Lloyd. Annual Report, 1866, 29.
} 
it is in the early 1870 s that Decoursey was named as the co-owner of a steam mill. ${ }^{100}$ Yet each of the men is referred to as a sugar cane farmer or sugar manufacturer prior to acquiring a stem mill. ${ }^{101}$

Assuming that the men did not possess steam mills, they had two means of making sugar. For a fee, they could convert they sugar cane into sugar at one of the facilities owned by the other planters. The other alternative was that the men manufactured sugar on their respective plantations because they possessed wooden mills and sugar houses. Evidence indicates that by 1865 , Roe and Howland did manufacture their own sugar. Proof of this latter explanation is found in the story, "A Day on the St. Paul's River," which was cited earlier:

Promising to return ... we took the road in the direction of Mr. Roe's farm... We stopped at friend Roe's and visited his sugar house, too. Mr. Roe has some very fine oxen, seven yokes ... We were some time passing the luxuriant cane of Mr. Howland, before we reached his dwelling ... We visited his sugar-house, saw his fine oxen ... and started homewards. ${ }^{102}$

There are three hints of a mill in the narrative: the sugar farm, sugar house and oxen. First, it would have been highly unusually for Roe or Howland to construct a sugar house when either of them owned a mill. Historian Richard Dunn suggested that in the West Indies, the mill and sugar house were situated side by side to enable workers to transfer the extracted cane juice to the sugar house "within a few hours" so the quality of

\footnotetext{
${ }^{100} \mathrm{AR}, 1869,185 ; \mathrm{AR}, 1873,249$.

${ }^{101} \mathrm{AR}, 1863,311 ; \mathrm{AR}, 1865,139$.

${ }^{102} \mathrm{AR}, 1865,139$.
} 
the manufactured sugar did not deteriorate. ${ }^{103}$ This pattern seems to have been adopted in Liberia.

Second, because the mill was the primary equipment or "the primum Mobile of the whole work," in the words of one seventeenth-century West Indian historian, ${ }^{104}$ a sugar cane farmer did not construct a sugar house to manufacture sugar unless he or she first possessed a mill. Anderson emphasized the importance of the mill when he explained that anyone with the "desire for farming" must first possessed a mill. ${ }^{105}$ All the sugar manufacturers in Liberia owned sugar cane mills. Finally, the "fine oxen" that the Roe and Howland possessed suggest the presence of an animal-powered mill on both farms. For instance, Roe's "seven yokes" or fourteen cattle, was twice the total that he needed at any given time to grind sugar cane.

One of the earliest indications that Roe had bought a steam mill appeared in the Liberian Advertisements of 1869 . He is reported as the owner of a "twelve-horse power" steam mill. In the announcement, Roe assured the public that "orders for sugar will be promptly attended to." 106 Roe's sugar cane business continued to prosper in the next decade. Around 1874, just about the time the price of sugar reached its lowest, the African Repository reported that several of the prominent sugar manufacturers, including Roe, were "doing good business." 107 That report was probably one of the last

\footnotetext{
${ }^{103}$ Dunn, Sugar and Slaves, 195.

${ }^{104}$ Ibid., 192.

${ }^{105} \mathrm{AR}, 1863,29$.

${ }^{106}$ The True Whig, cited in AR, 1869, 184-185.

${ }^{107} \mathrm{AR}, 1874,40$.
} 
encouraging signs about Roe's sugar manufacturing business in the decade. By the 1880s, Roe's "good business," like the majority of the enterprising sugar cane farmers', had ceased operation.

There are no clues that Decoursey, who was a sugar cane and coffee planter, was the owner of a wooden mill. He probably processed his sugar cane into sugar at the mill and sugar house of one of the other planters. This practice, as I will later demonstrate, was common among cane growers and sugar manufacturers. In 1869, Decoursey was listed in the Liberian Advertisements as a "planter and manufacturer of sugar, coffee and dealer in African products." ${ }^{108}$ The African Repository declared in 1873 that Decoursey and Dr. C. B. Dunbar owned a steam mill, described as "perhaps the best steam engine" on the St. Paul. ${ }^{109}$ By the second half of the 1870 s, Decoursey reportedly owned "the largest coffee plantation in Liberia" and in 1880 , he was also one of the "most extensive" sugar cane farmers. ${ }^{110}$ But Decoursey's rise to the top of the sugar industry was hardly significant because the age of the "mania for sugar estates" had virtually come to an end.

\section{The Latecomers}

Two farmers that bought mills in the waning days of the sugar cane era were Jefferson Bracewell and J. B. Roulhac. Bracewell emigrated from Valdosta, Georgia, in 1871 with a family of about ten persons. Roulhac may have arrived at the same time or shortly thereafter. In March of 1873, one immigrant wrote that Roulhac and Bracewell

\footnotetext{
${ }^{100}$ The True Whig, cited in AR, 1869, 185.

${ }^{109} \mathrm{AR}, 1873,249$

${ }^{110}$ Ibid., 1877, 109-110; Ibid., 1880, 27.
} 
owned "two sugar mills" and the men were "grinding cane every day." 111 About five months later, a correspondent of the African Repository reported that Bracewell had "several barrels of as fine a quality of sugar and molasses or sirup as I have ever seen raised and made in Liberia." 112 Bracewell was primarily a coffee farmer. He and Decoursey would play an influential role in the "mania" for coffee that followed the collapse of the sugar industry. The causes for the collapse of Liberia's promising sugar business are discussed separately in Chapter VI.

\section{The "Poor Man" and the Sugar Cane Industry}

The vast majority of the settlers were actually too poor to meaningfully participate in the labor- and capital-intensive sugar cane industry. Anderson calculated that to be profitable, the Liberian farmer had to cultivate 2 acres of sugar cane, possess a wooden mill and a capital of about $\$ 200 .^{113}$ This requirement was beyond the reach of a majority of the settlers. A letter written by ex-slave William Burke, offers an excellent illustration of the poverty of the immigrants. Burke, who was one of the fortunate few to receive small cash gifts from his master prior to departure, was emancipated by Lee and emigrated to Liberia with his family in 1853. A year later, Burke wrote Mr. and Mrs. Lee from Liberia. He mentioned, among other things, that he had a little more than $\$ 100$, "with what you gave me," before his emigration to Liberia. Burke told his former owners that he spent some of the money in the United States on "board for two weeks" and began

\footnotetext{
${ }^{111}$ Ibid., 1873, 253.

${ }^{112}$ Ibid., 346.

${ }^{113}$ Ibid., 1863, 29.
} 
the voyage with $\$ 33$. In Liberia, he and his family stayed for most of the first six months with an agent of the ACS, apparently without paying for the accommodation. At the end of the sixth month, Burke recounted, he and his family, consisting of a wife and "four small children," began their new life in Liberia with "only \$3 in cash." ${ }^{114}$ In several subsequent letters, Burke emphasized to the Lees that it was impossible to succeed as a farmer without money. He wrote in 1854: "A little money here, can do but little with regard to farming, and that is certainly the surest and best avenue to wealth, ease and comfort. The only farmers here who are making anything for sale, are those who come to this country with money." 115 Furthermore, many of the poor settlers, who subsisted on whatever they could produce, found sugar cane cultivation (along with the other perennial crops) less attractive because of the long gestation period, which was noted earlier. For these subsistence farmers, growing vegetables, like sweet potatoes, was more important for their survival.

\section{The Toll System and the Sale of Fields of Cane}

Notwithstanding the poverty and the long period of growth, a small group of settlers who did not own mills attempted to become sugar manufacturers. Some poor farmers were motivated to grow sugar cane because the enterprising farmers, who owned the mills and sugar houses, were willing to convert their crops into sugar for a price or a toll. Based on a mutual agreement, the sugar manufacturers would grind the sugar cane for the small farmers and process it into sugar for a portion of the yield. The small

\footnotetext{
${ }^{14}$ Wiley, Slaves No More."

${ }^{115}$ Ibid., 191.
} 
farmers could in turn sell the sugar locally to consumers or the manufacturers, who later shipped it abroad. Sugar manufacturers charged a slightly different toll rate over the years. For example, the advertisement of John B. Jordan, which appeared in the 1856 edition of the Liberia Herald, stated that

The undersigned having obtained a steam sugar mill for making sugar ... hereby gives notice that he will be prepared ... to serve the public, upon the delivery of the Cane, at his mill door for a Toll of one fourth of the next yield. ${ }^{116}$

It seems that Jordan allowed the small farmers to defer the payment of tolls on the first consignment of sugar cane. About three years later, Anderson explained that he requested a toll of "one fourth of the proceeds" from "neighboring farmers" for grinding their cane. He indicated that the toll the Coopers requested was higher: it was "one-half" of the farmer's yield. ${ }^{117}$ Some of the enterprising farmers probably used the toll system prior to purchasing their own mills. In 1859 Washington sent his cane to Anderson's mill. ${ }^{118}$ Lloyd may have used Anderson or the Coopers' sugar equipment to process the large quantity of sugar cane he had before he obtained his steam mill in 1864 . Decoursey may have also used the toll system when he did not have a mill.

Besides the toll system, small farmers could sell their unharvested sugar cane to the wealthier farmers. This was the arrangement that Lloyd made with a group of small farmers in 1864 , when he decided to concentrate solely on manufacturing sugar. He promised the small farmers that he would "purchase all their cane, standing, at a definite

\footnotetext{
${ }^{16}$ Liberia Herald, 6 August 1856.

${ }^{117} \mathrm{AR}, 1859,302$.

${ }^{118}$ Ibid., 1859, 248.
} 
price; remove it, and grind and manufacture."119 The decision must have been popular. A letter in the African Repository applauded the decision and predicted that

This will cause a revolution in cane planting in this country. Poor men cannot spare the capital to get mills for their farms; those who venture to do so, as several have, find but little advantage, for to make money a mill ought to be kept going at least four months. ${ }^{120}$

In spite of the opportunity to manufacture their sugar or sell their fields of sugar cane to the wealthier farmers, not many poor farmers cultivated sugar cane. Ultimately, it was the cost that precluded the ordinary settler from cultivating sugar cane. Thus, in 1867 a Liberian immigrant noted that most sugar cane farmers had given up sugar cane for another crop because of the "cost of preparing the sugar farm."121 Abraham Hanson, the Commissioner and Consul-General of the United States, suggested that the toll system discouraged many. The Consul-General wrote in 1866 that Lloyd's mill was idle because of "the heavy cost of toll and transportation." 122

The toll (one-fourth and one-half of the farmer's yield) ) combined with the precipitous fall in the price of sugar certainly discouraged the small planters. On the other hand, Lloyd and the owners of the steam mills may have been reluctant to lower the toll, because of high cost associated with operating the sugar cane business. In the end, however, neither the toll system nor the opportunity to sell their fields of cane, could keep

\footnotetext{
${ }^{\Pi 19}$ Ibid., 1864, 188.

${ }^{120}$ Ibid.

${ }^{121}$ Ibid., 1867, 215.

${ }^{122}$ Ibid., 1866, 67.
} 
the poor settlers in the sugar industry. As a result, sugar manufacturing remained exclusively in the hands of the ten enterprising farmers.

\section{Costs of Investment: The Mills and Kettles}

The paucity of information on how much was invested in sugar production makes it difficult to estimate the total sum of money that was invested in the sugar industry. There are, however, some data on the mills and kettles that were purchased which could be used to estimate how much was invested in sugar manufacturing. From 1850 through the 1870 s, the Liberian farmers bought no less than twenty sugar cane mills. Seven or more of them were steam-powered sugar cane mills. According to Abraham Hanson, the United States Consul-General, the "smaller" steam engine sugar cane mill Sharp bought, cost "two thousand, or two thousand five hundred dollars." 123 The ACS reported that the price of Richardson's steam mill (which was devolved to Anderson) was “over $\$ 6,000 . " 124$ Lloyd's 35 -horse power mill, which was purchased about five years later and considered the largest in the country, was probably the most expensive. Assuming that Richardson's mill cost a minimum of $\$ 6,000$ and the most expensive mill purchased by Lloyd was $\$ 7,000$, the total price of both steam mills would have equaled at least $\$ 13,000$. If the amount of $\$ 2,000$ (the minimum price for Sharp's mill) is the individual cost of each of the remaining smaller five mills, then a grand total of $\$ 23,000$ was expended on the seven steam mills.

${ }^{123}$ Annual Report, 1866, 29-30.

${ }^{124}$ Ibid., 1859, 15. 
As noted in the beginning of the chapter, kettles were the next most expensive piece of equipment. The greater the quantity of extracted cane juice, the higher the number of kettles required. In 1867 Washington operated "seven or eight large kettles." 125 Anderson suggested he operated a single kettle in $1862 .{ }^{126}$ It is almost certain that Anderson bought more kettles because he later expanded his sugar cane farm. Jefferson Bracewell ordered "two boilers, one fifty and the other holding sixty gallons." 127 Based on the total number of kettles mentioned above, it is reasonable to assume that each of the owners of the seven steam mills operated an average of two or three kettles. Each kettle cost $\$ 750$ in the United States. ${ }^{128}$ If the seven farmers ordered only two kettles from the United States during the entire sugar cane era, the total amount would be $\$ 10,500$.

So, all together the enterprising farmers invested an estimated total of $\$ 33,500$ in seven steam sugar cane mills and fourteen kettles between approximately 1856 and the end of 1880 s. This is obviously a conservative estimate. The total will certainly go up if more information becomes available on the individual cost of thirteen human and animal mills mentioned in a 1865 report. Additionally, the cost of labor will definitely raise the total sum of money invested in the sugar industry. Yet, even the $\$ 33,500$ was a substantial investment.

\footnotetext{
${ }^{125} \mathrm{AR}, 1867,216$.

${ }^{126}$ Ibid., 1863, 28-29.

${ }^{127}$ Ibid., 1872, 284.

${ }^{128}$ Sitterson, Sugar Cane Country, 160.
} 
$\underline{\text { Sugar Output }}$

The scarcity of data makes any conclusion reached on the quantity of sugar that was produced tentative. Total output can be derived from the estimates that the farmers and the Liberia Herald projected. Anderson's comments, made in 1862, stated that

During this year there has been shipped to the United States about fifty thousand pounds; to the English settlements, below us, two thousand pounds; to our settlements along the coast, twenty thousand pounds, including what has been used in Monrovia. Excluding what has been used among the planters along the river, this still leaves a quantity in store, awaiting opportunity for shipment. ${ }^{129}$

Anderson made the comments in September or October. Therefore, the total of 72, 000 pounds could be used as an estimate for the whole year. If the total is multiplied by 10 (i.e., 1862 to 1872 ) an estimated 720,000 pounds of sugar would have been sold over time. The estimates based on Anderson's figures do not account for the changes in output over the years, especially between 1864 and 1875, when sugar cultivation reached a peak. For example, between 1863 and 1865, total sugar cane acreage increased from 209 to 682. ${ }^{130}$ Another indication that output may have increased throughout the sixties and early seventies is the number of mills that were purchased. A total of seven mills, five of which were steam-operated, were bought during the 1860 s and 1870 s. These five steam engines represent the highest number purchased in the entire sugar cane era. Therefore, if Anderson's yearly total of 72,000 is tripled to account for the increase in acreage (i.e., 209 to 682 ) a total of 2.3 million pounds of sugar would have been produced between 1862 and 1872.

${ }^{129}$ Ibid., 1863, 28.

${ }^{130}$ Ibid., 1865, 44. 
According to a projection in the Liberia Herald, farmers manufactured approximately 4.2 million pounds of sugar in $1865 .{ }^{131}$ Based on this estimate, farmers have manufactured a total of 42 million pounds of sugar between 1865 and 1875 . One possible explanation for the huge discrepancy between Anderson's total and that of the Liberia Herald, is the large difference in the quantity of sugar that each source estimated could be obtained from an acre of sugar cane. In 1862, Anderson stated that farmers "do not receive over 1,500 pounds" of sugar to an acre. On the other hand, the 1865 estimation by the Liberia Herald projected that the 682 acres would yield 4.2 million pounds of sugar, which translated to about 6,000 pounds of sugar per acre. ${ }^{132}$

The huge difference in the two estimates of the quantity of sugar derived from an acre, was probably the result of a colossal error. Or perhaps the farmers had become more efficient in sugar production when the newspaper made the estimate in 1865 . This latter assumption is based on a comment by Anderson. When Anderson gave his estimate of sugar per acre in 1863 , he indicated that farmers were not too familiar "with the science both of manufacture and the proper time of cutting the cane in order to get the greatest saccharine matter." 133 The fact that improper timing could ultimately lower the quantity and quality of sugar, makes the argument for improved or greater efficiency plausible. In any case, something between the 2.3 million and 42 million is the best

\footnotetext{
${ }^{131}$ Liberia Herald, (n.d.), quoted in AR, 1865, 44.

${ }^{132}$ The Liberia Herald gave the following explanation for its projection: "We have, to begin with, 682 acres of cane, which ought to give 1,880 hhds. of sugar of 2,240 lbs. each. That is allowing the yield to be per acre $2 \frac{1}{2}$ and 3 hhds., which we have been told is the case; then we would have 4,211,200 lbs. of sugar." AR, 1865, 44; Ibid., 1863, 27.

${ }^{133} \mathrm{AR}, 1863,27$.
} 
estimate that can be derived from the data that is available, for the total pounds of sugar that was produced by the Liberian farmers during 1862 to 1872 .

I conclude the chapter by emphasizing two points. First, the availability of capital and equipment in Liberia was the catalyst that spurred sugar production in the second half of the century. In the first half of the century sugar production was hindered, among other factors, by the lack of mills. When farmers had access to mills (especially steam mills) after the 1840s, sugar cane cultivation expanded and sugar was manufactured for sale abroad. During the decade of the sixties, which was the peak of the "mania for sugar estates," the highest number of steam mills was purchased. In 1864 alone, the planters bought three steam mills to grind the growing volume of cane that were being cultivated. This direct relationship between the availability of mills and sugar cane expansion proves that only with capital and equipment could commercial agriculture thrive in Liberia. Hilary Teage and Ralph Gurley had correctly predicted that this would be the case.

The second point of interest is the similarity in the social status of those who were involved in commercial agriculture. It was demonstrated that prior to the $1850 \mathrm{~s}$, the majority of the small group of farmers were educated and relatively wealthy. The same can be said (to some extent) the enterprising farmers. Six of the ten enterprising farmers could read and write. Aside from Augustus Washington, there is no precise information on how much money each of the enterprising farmer had at the time of emigration. Yet, it is safe to assume (given that they invested in sugar production shortly after arrival) that many of them had far more resources than the vast majority of destitute settlers. Taken together, this means that nearly all of the commercial farmers were literate and fairly well 
off. For now, this finding contradicts the standard interpretation in the historiography that claims the educated class of Americo-Liberians neglected agriculture. ${ }^{134}$ It has been established that the progress made in sugar production was undertaken by the educated upper class because they, and not the impoverished majority, had the resources to buy mills and construct sugar houses. Did these elites also invest in coffee production? This question will be answered in the next chapter.

${ }^{134}$ See, for example, Sawyer, The Emergence of Autocracy, 105; Liebenow, Liberia: The Evolution of Privilege, 12-13. 


\section{CHAPTER IV}

\section{COFFEE FARMING 1850-1890s}

All classes of our citizens are planting coffee. Mercantile and professional men find it a satisfactory way of investing superfluous capital and spending their spare time, while the Aborigines around, especially the Kroomen, are following the example thus set, and are in large numbers becoming agriculturalists.

-American Colonization Society Annual Report, $1892^{1}$

An Overview of Coffee Cultivation, 1850 to ca. 1860

Some of the conditions that shaped coffee production occurred in the period 1850 to 1860 . The most important development was the attention that Liberians gave to coffee in spite of the "mania for sugar estates" which I mentioned in the previous chapter. While the small group of enterprising sugar cane farmers was setting up mills and sugar houses, a larger number of Liberians were turning to coffee. I have identified four reasons why Liberians manifested such interest in coffee, the mysterious berries that Ethiopian folklore claimed a young herder and his "dancing goats" discovered over 500 years $\mathrm{ago}^{2}$. The reasons are the relative inexpensiveness of growing coffee, the productiveness of the Liberian coffee plant, the compatibility of coffee to the Liberian climate, and the favorable international market.

Farmers believed that preparing a coffee farm was not as labor- and capitalintensive as cultivating sugar cane. Two systems of coffee cultivation were practiced in

\footnotetext{
Annual Report, 1892, 9.

${ }^{2}$ Gregory Dicum and Nina Luttinger, The Coffee Book: Anatomy of an Industry From Crop to the Last Drop (New York: The New Press, 1999), 2-8; Pendergrast, Uncommon Grounds, 4.
} 
Liberia. One method was to clear the field, dig holes in "rows of 12 feet apart" and insert the young coffee plants collected from the wild. ${ }^{3}$ In the second method, coffee seeds were planted in a nursery and within twenty-four months the young shoots were transferred onto the cleared field. ${ }^{4}$ Farmers were unanimous in their opinion that either method was by far cheaper than laying out a sugar cane field: "The cost of preparing a coffee farm" one immigrant wrote, "is comparatively trifling as compared with the cost of preparing a sugar cane farm."

Productivity, the second reason why Liberian farmers were attracted to coffee, was also based on a comparison with sugar cane. The fact that the coffee plant was a perennial crop gave it an economic advantage over sugar cane as far as the cost of replanting was concerned. Sugar cane was a seasonal crop and as a result, farmers had to replant their fields after every harvest. On the other hand, the coffee tree could produce berries for many decades. One report indicated that coffee trees in Liberia could bear fruit continuously "from ten to twenty years." Another account suggested that the coffee tree could remain productive for over four decades. According to this latter account, a coffee tree was planted in the "Government Square in Monrovia" in 1824 and by 1866 the tree had been bearing coffee consistently "every season." It was probably another comparison with sugar cane that led the farmers to choose coffee.

\footnotetext{
3 AR \& CJ, 1848, 309.

${ }^{4} \mathrm{AR}, 1882,120$.

${ }^{5}$ Ibid., 1867, 215.

${ }^{6}$ Lugenbeel, Sketches of Liberia, 23.

${ }^{7} \mathrm{AR}, 1886,71$.
} 
Many of the settlers and foreign residents were convinced that coffee grew exceptionally well Liberia. ${ }^{8}$ It was the compatibility of coffee to the climate that made the plant grow luxuriantly in the lowlands and rocky uplands. It was on the hilly land of the interior, however, with decaying vegetation and the dense forest canopy that the Liberian coffee prospered more abundantly. The fact that the coffee thrived so well, helped to foster the notion that it was indigenous to Liberia. That assumption was given an added boost in 1876 when the Linnean Society of London recognized the Liberian coffee as a distinctive species and assigned a new scientific name to it. The name was Coffea liberica (C. liberica). ${ }^{9}$ Yet, others believed that the coffee was introduced to the pre-Liberian coast by Portuguese mariners prior to the nineteenth century. ${ }^{10}$ Whatever its origins, the $C$. liberica is widely acknowledged by contemporary writers to be native to Liberia. $^{11}$

The final reason for the appeal of coffee, the favorable international market, involved two issues. The first was in regards to the exposure that Liberian coffee received in the United States and the second, the advantageous price of coffee in the United States. In the 1850 s, some coffee consumers in the United States had developed a somewhat flattering opinion of Liberian coffee. Prior to the mid-century, Liberian farmers had occasionally sent small samples of coffee to the United States. The recipients of the samples were mainly former slave masters and officials of the ACS.

\footnotetext{
${ }^{8}$ For example, Ibid., 1842, 233; Ibid., 1863, 180; Ibid., 1882 119-120.

${ }^{9}$ George Stockham and Edward Morris, Liberia Coffee (Philadelphia, 1887), 12.

${ }^{10} \mathrm{AR}, 1882,120$.

${ }^{11}$ See, for example, V. D. Wickizer, The World Coffee Economy: With Special Reference to Control Schemes (Stanford: Stanford University Press, 1949); Pendergrast, Uncommon Grounds;
} 
They gave samples of the coffee to acquaintances and business houses. Thus, by the end of the 1850s a small number of Americans had become familiar with the Liberian coffee. Many of the Americans, who had tasted the coffee, considered it "superior" to the World famous Mocha coffee from Ceylon. ${ }^{12}$ One delighted consumer wrote: "We have tried the coffee, and our family concurs in the opinion that it is of superior quality." 13

Finally, the attraction of the Liberian coffee to the few Americans who examined it occurred just about the time when the price of coffee had begun to improve after successive losses. This increase in price was due primarily to increasing demand. In the United States, annual individual consumption of coffee rose steadily over several decades. For example, "per-capita consumption grew to three pounds a year in 1830 , five and a half pounds by 1850 , and eight pounds by $1859 .{ }^{\prime 14}$ During the American Civil War (1861-1865), the price of coffee began to increase for the first time in a number of decades. For instance, a pound of coffee sold for 42 cents by the end of the war, having risen from 14 cents in $1861 .^{15}$

The rest of the chapter is organized chronologically. In the first period, which begins from 1850 s and ends in 1862 , I focus mainly on the cultivation of coffee in two regions that turned out to be the primary producers. The second era, covering the period 1863 to 1876 , is actually the turning point in the Liberian history of coffee production. Its central theme is the favorable international recognition that was bestowed on the Liberian

\footnotetext{
AR, 1853, 247-248.

${ }^{13}$ Ibid., 247.

${ }^{14}$ Pendergrast, Uncommon Grounds, 46.

${ }^{15}$ Ibid., 46-48.
} 
coffee. The final period, 1876 to 1890 s, looks at several issues, including the coffee boom, the shift from one coffee center to another and a brief discussion of the status of some of the wealthy planters. First, a summary of some of the main features of coffee production is presented below.

\section{The Coffee Huller, the Coffee Planters and the Coffee Regions}

As noted in the epigraph at the beginning of the chapter, by the last decade of the century, Liberians from various social categories cultivated coffee. One of the reasons that was given for the appeal of coffee was its low capital and labor requirements. This is true, to an extent. To become a successful coffee producer, the farmer needed one major piece of equipment. That device was the hulling machine, used mainly to remove the rind that encased the coffee beans.

The traditional method for cleaning the harvested coffee berries was timeconsuming and wasteful. After drying the berries, the farmers placed small quantities in a mortal and pounded them with a pestle until the skins fell out. The procedure was laborious and required a steady number of workers. Usually, some of the coffee beans were destroyed in the process. In 1847, for instance, George R. Ellis McDonogh, a Liberian immigrant, sent some coffee to his former owner. McDonogh explained that the coffee was "little more matched than the coffee generally, as we have to clean it by beating it in a mortar."16

It appears that until the early 1870 s, there was only one mechanical huller in Liberia. The machine was owned by coffee planter Stephen Allen Benson, who was

\footnotetext{
${ }^{16}$ Wiley, Slaves No More, 146-147.
} 
President of Liberia from 1856 to 1863 . In 1855 , several months before being sworn into office, Benson informed an acquaintance that he was leaving his coffee farm "somewhat reluctantly," because he had "now a mill [huller] constructed by Liberian ingenuity . . . I can put out one thousand pounds of coffee in marketable order in a week." ${ }^{17}$ Given the advantage that the huller had over the mortar and pestle, one can probably understand why President-elect Benson was reluctant to leave his farm.

Another feature of coffee production that should be considered is the social class of the producers. Even though the ACS reported that "all classes," including the indigenous people, grew coffee (quotation at the beginning of this chapter), the evidence shows that the planters were still practically the elite Americo-Liberians. These latter coffee growers were from the same social category as the early coffee planters that were discussed in Chapter II and the enterprising sugar manufacturers in Chapter III. They were generally literate and relatively affluent.

Finally, unlike sugar production, which was concentrated solely along the St. Paul River, coffee was grown in all five counties in the republic by the end of the nineteenth century. However, two counties, Montserrado and Grand Bassa, produced all or most of the coffee that was sold overseas. Coffee was cultivated almost entirely in two regions of these counties. In Montserrado County, coffee was grown on the hilly interior land of the St. Paul River, while the surrounding area of the St. John River in Grand Bassa became the other coffee-producing center. Both regions seem to have been well suited for the cultivation of coffee. The mixture of loamy soil and small rocks plus the lush forest canopy, provided an excellent climate for growing coffee.

${ }^{\Gamma \mathrm{AR}, 1856,18 .}$ 


\section{Coffee Production, 1850 to ca. 1863}

\section{St. John Leads St. Paul}

Liberians' response to the growing demand for coffee in this period was impressive, although the official count appears to suggest otherwise. If the list of farmers on the St. Paul that sugar planter Jesse Sharp prepared in 1863 is any indication, then the number of coffee trees had risen from merely 21,197 in 1843 to $32,800 .^{18}$ The fact that the list does not include the coffee trees of the St. John River, is the main reason why the count is so low. There are pieces of evidence that indicate the settlers of the St. John River in Grand Bassa County were the leading coffee producers by 1863 . In 1852 , the African Repository published an excerpt from an agricultural report in the Liberia Herald. The story stated that "Grand Bassa has gone far ahead of every other part of Liberia in the cultivation of coffee."19 Less than a decade later, the ACS noted the dominant role of Bassa in the coffee trade when it observed that Bassa was "a principal mart for palm oil and coffee trade." ${ }^{20}$ Another report by Reverend C. C. Hoffman, an American Christian missionary and a resident of Liberia, made the following observation about the role of Bassa in the coffee trade in 1862 :

When I went there, there was a large number of coffee trees planted, but there was but little coffee picked at that time ... but now the people are engaged in trade and commerce .... At Bassa sometimes 100 bags [coffee] are exported. The climate furnishes a fine field for its cultivation. ${ }^{21}$

\footnotetext{
${ }^{18} \mathrm{AR}, 1863,310-311$; "The Census"

${ }^{19}$ Liberia Herald, (n.d.), quoted in the AR, 1852, 242.

${ }^{20}$ Annual Report, 1861, 21.

${ }^{21} \mathrm{AR}, 1862,37$.
} 
The major coffee farms of the St. John were concentrated in three settlements. They were Edina, Bassa Cove and Bexley. Edina, the oldest of the three settlements, was founded in $1832 .{ }^{22}$ It was located about half a mile inland from the Atlantic coast. The coffee plantation of William Weaver, who was previously mentioned as one of the leading planters in the 1840s, was located in Edina. Bassa Cove, the second oldest town, was established by the Pennsylvania Colonization Society in $1835 .{ }^{23}$ Bassa Cove was governed separately until 1839 , when it joined the Commonwealth of Liberia. By the end of 1863, former President Benson was perhaps the largest coffee farmer in Bassa Cove. Bexley, the last of the three towns, was founded in 1838. William Sheridan, the "distinguished Negro capitalist," lived in Bexley. If the number of coffee trees in these settlements is added to Sharp's list, the total for the period will exceed the original 32,800 .

At the St. Paul River, the bulk of the coffee was cultivated in two of the seven settlements sugar planter Jesse Sharp enumerated in $1863 .{ }^{24}$ They were Kentucky (i.e., Clay-Ashland, mentioned in Chapter III) and Virginia or New Virginia, the latter established in $1846 .{ }^{25}$ Together, the two settlements accounted for 31,000 of the 32,800 coffee trees or about 95 percent of the tress that Sharp counted. ${ }^{26}$

\footnotetext{
${ }^{22}$ Karnga, History of Liberia, 26.

${ }^{23}$ Ibid.

${ }^{24} \mathrm{AR}, 1863,310-311$.

${ }^{25}$ Lugenbeel, Sketches of Liberia, 10.

${ }^{26} \mathrm{AR}, 1863,310-311$.
} 


\section{The Planters}

There appears to be no "aborigines" or indigenous coffee planters in the period under consideration. Coffee farming was in the hands of a small group of AmericoLiberians. In 1863, the prominent planters were Stephen Benson, Allen Hooper and Abraham Blackledge. Stephen A. Benson was a planter and merchant. ${ }^{27}$ He was born of free parents in Maryland in the United States and traveled to Liberia with his parents in 1822. ${ }^{28}$ He later left Monrovia, where the family had settled, and relocated to Grand Bassa. Not much is written about Benson's coffee farm. Yet, the evidence suggests that he was a prominent coffee planter. It can be recalled that Benson was the owner of the locally-assembled coffee huller. In 1863, the year Sharp published his list of farmers of the St. Paul, an official of the ACS in the United States described Benson's coffee plantation as a "large coffee estate." ${ }^{29}$ Benson died two years later.

Allen B. Hooper probably owned the highest number of coffee trees in the St. Paul region by 1863 . He arrived in Liberia in 1850 . Although the ACS assigned "Unknown" to Hooper under the column for education at the time of emigration, he was obviously literate as evidenced by his letter of $1878 .^{30}$ There is additional proof that Hooper was educated. Like many of the literate planters, Hooper assigned names to his farms or farm on the St. Paul (i.e., Iconium and Ridgeland). ${ }^{31}$ Hooper's estate was

\footnotetext{
${ }^{27}$ Ibid., 121.

${ }^{28}$ Ibid., 1865, 154-155.

${ }^{29} \mathrm{AR}, 1863,121$.

${ }^{30}$ See a letter written by Hooper. AR, 1878, 38; Robert T. Brown, Immigrants to Liberia, 33.

${ }^{31} \mathrm{AR}, 1873$; Liberia Herald, (n.d.), quoted in AR, 1852, 240.
} 
located in Kentucky. When Sharp prepared his list in 1863, he did not include a number for the quantity of trees on Hooper's farm. He simply wrote "many." 32 The "many" appears to suggest that Hooper's trees exceeded the highest individual total of 10,000 on the list. ${ }^{33}$

There are other clues showing that Hooper cultivated a large coffee estate. In 1852, the Liberia Herald lauded Hooper as the "most systematic in farming of all Liberia agriculturalists." ${ }^{34}$ The paper went on to praise Hooper:

It would be silly in us to attempt a description of Mr. H's beautiful place-it is yet two years since what is now his farm, was complete wilderness-it was the home of the wild animals of the forest - it is now . . beautifully laid off ... In the rear of the house, the staple articles of the country, coffee and sugar cane are growing; ... If one wishes to see a very handsome place, - beautiful nurseries of coffee and cotton, he must visit "Iconium." 35

A year later, an excerpt from a letter carried by the New York Tribune was published in the African Repository. According to the writer, Hooper owned " 70,000 or 80,000 coffee trees; 7,000 of these will bear next season for the first time." ${ }^{36}$

Abraham Blackledge, the other influential coffee planter of the era, was called the "pioneer of sugar cane and coffee" of the St. Paul. I alluded to Blackledge in Chapter III as one of the earliest sugar manufacturers on the St. Paul. In 1863, his coffee farm was located in Virginia. Blackledge, who was literate, arrived in Liberia in $1842 .{ }^{37}$ By 1863 ,

\footnotetext{
${ }^{32} \mathrm{AR}, 1863,311$.

${ }^{33}$ Ibid.

${ }^{34}$ Liberia Herald, (n.d.), quoted in AR, 1852, 240.

${ }^{35}$ Ibid.

${ }^{36} \mathrm{AR}, 1853,301$.

${ }^{37}$ The Census.
} 
he owned 10,000 of the 32,800 coffee trees in the St. Paul. ${ }^{38}$ Blackledge died before the crop he helped to introduce on the St. Paul achieved international fame.

\section{The Turning Point: $1865-1876$}

\section{The "Morris Factor"}

If a single foreigner deserves credit for promoting Liberian coffee abroad, it has to be the American, Edward Morris. He, almost singlehandedly, took the coffee from the Liberian forest and placed it in the international spotlight. Morris was a businessman from Philadelphia and an official of the Pennsylvania Colonization Society, an auxiliary of the ACS. His arrival in Liberia in 1862 coincided with the expansion of coffee farming. In one of his several speeches, Morris told Liberian farmers that

The Merchants' Magazine for September, 1861, says that the upward tendency of the prices of coffee has been in consequence of the increased consumption of it, both in Europe and the United States ... At the present time the ordinary consumption of Coffee in the United States alone is from forty-five to fifty thousand tons every six months. The demand ... rapidly increases, while the supply is constantly on the decline. ${ }^{39}$

Morris assured his audience that he would provide them with the necessary technology to stimulate coffee production. The technology was the coffee huller.

In the meanwhile, Liberians responded with renewed vigor to Morris' lectures on the benefits of growing coffee. The United Sates Consul, Abraham Hanson, informed Morris in a letter that "some men of capital and indomitable enterprise, ... proposed, for

\footnotetext{
${ }^{38} \mathrm{AR}, 1863,310$.

${ }^{39}$ Edward S. Morris, "An Address Before the Liberia Union Agricultural Enterprise CO.: At Clay Ashland on the St. Paul's River." (Philadelphia: WS. S. Young, 1863), 7-8.
} 
the first time, to engage in the cultivation of coffee, as the result of the impetus and inspiration." ${ }^{40}$ William C. Burke (General Robert Lee's ex-slave) wrote:

Mr. E. Morris, from Philadelphia, has given several valuable lectures on farming operations. He has gotten some good quality of coffee from the St. Paul's river. The attention of almost every farmer has been lately turned towards raising coffee, and I regret that they have not done so before. I am operating on a hundred acres of land, about three miles back from the river. ${ }^{41}$

Reverend C. C. Hoffman, the long-time American resident with considerable knowledge on Liberian agriculture, sent a letter to Morris about the benefits Liberians would derive from the coffee huller:

I desire to express to you the great pleasure I feel in common with others in your efforts to develop the agricultural resources of Liberia, especially in the cultivation of coffee. The common method to bruise the coffee berry in a mortar, wash them, and pick the grains out by hand, is not only exceedingly laborious, but involving so much time and so great an expense, that valuable as the coffee is, it can scarcely be made to pay. The quantity cultivated must necessarily be very limited for want of laborers to clean the Coffee, ... Your Hulling Machine entirely removes this, ... All classes of the community have been aroused. The poor widow, as well as the prosperous merchant and the far seeing statesman, has been cheered by the prospect you have opened for individual benefit and the country's prosperity. ${ }^{42}$

Morris returned to the United States and for several years, worked on the construction of the hulling machine. Finally, in the early 1870 s, he sent the mechanical coffee huller to Liberia (Figure 5) The huller would play a significant role in coffee production.

In addition to providing the farmers with the huller, Morris strived diligently to promote Liberian coffee abroad. His store in Philadelphia was the principal center for the distribution of Liberian products, including coffee (Figure 6) He provided information

\footnotetext{
${ }^{\$ 0}$ Stockham and Morris, Liberia Coffee, 7.

${ }^{41} \mathrm{AR}, 1863,132-133$.

${ }^{42}$ Ibid., 1863, 179-180.
} 
and samples of Liberian coffee to the American public. The most important publicity that Morris gave the Liberian coffee was at the United States Centennial Exhibition in Philadelphia in 1876 . He was appointed by the Liberian Government to represent the nation at the Exhibition. Morris used his own resources to set up a display of Liberian products in the Agricultural Hall of the Centennial Exhibition. Among the Liberian products at the centennial were palm oil, palm kernel oil, palm soap and coffee (Figure 7). Morris's promotion was a huge success. His efforts were rewarded by two diplomas: the "U. S. Centennial Diploma Awards For Superior Coffee" (Figure 8) and the "Medals of Awards and Diplomas of Merit, For Superior Coffee and Palm Soap" (Figure 9 ). Morris' dedication generated significant publicity for Liberian coffee. In the United States, several persons wrote him to express their approval for the Liberian coffee. B. Silliman, a Professor of Chemistry at Yale College told Morris:

Some weeks since my attention was called to the Liberian coffee ... It was quite new to me and its quality was so much superior to most coffee in common use in this country that I at once ordered a sample... This opened a correspondence with yourself which led me to visit your exhibit, and also examine it critically. The result has been to satisfy me that the coffee of Liberia is equal to any coffee I have ever seen. ${ }^{43}$

William H. Allen, President of Girald College in Philadelphia, informed Morris that he would "give special preference to Liberia coffee over all others." The President concluded: "In strength, flavor and aroma, it combines the best qualities of the best varieties. ${ }^{44}$

\footnotetext{
${ }^{43}$ Ibid., 12-14.

${ }^{44}$ Ibid., 14.
} 


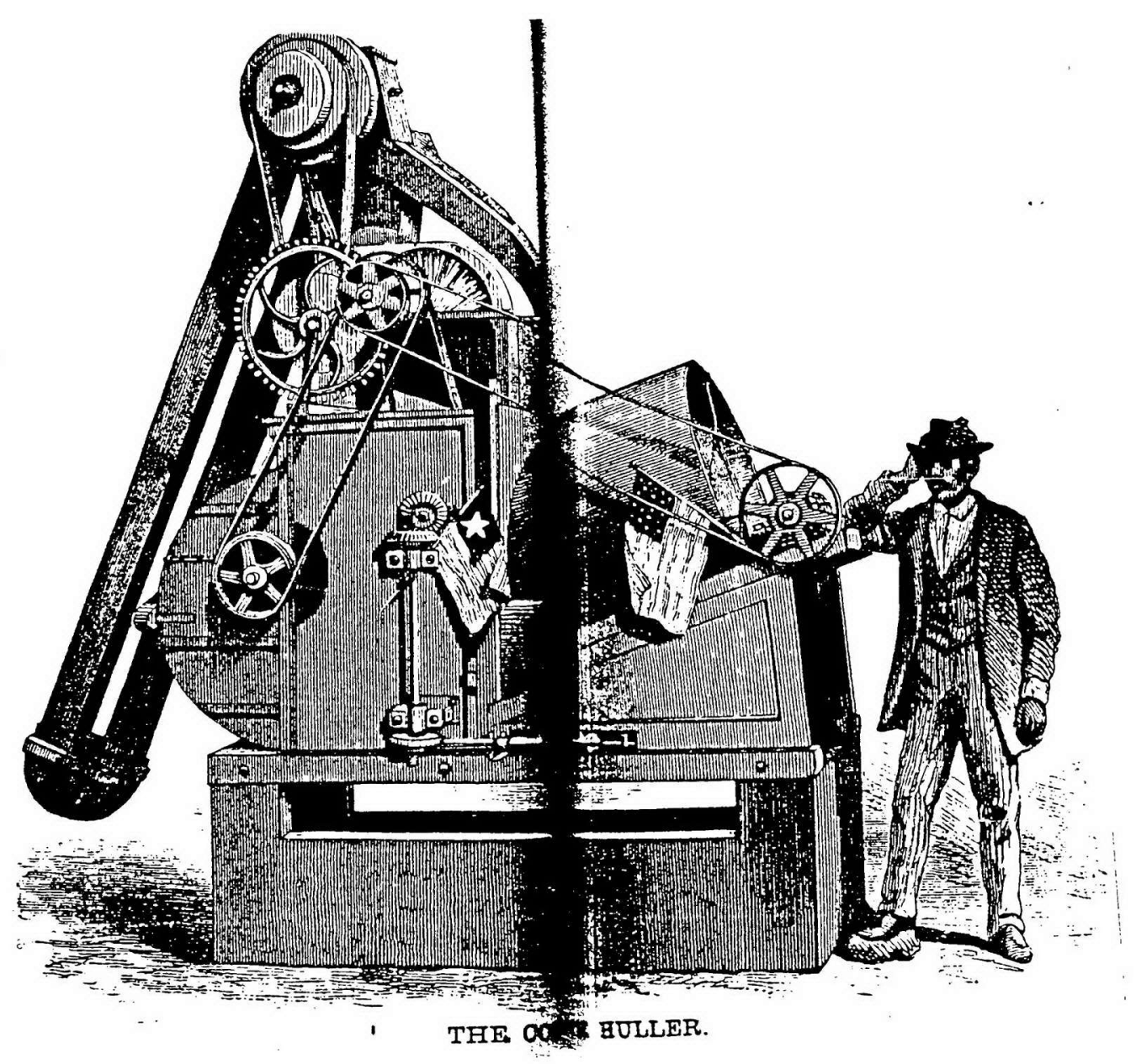

Figure 5: Coffee Huller. (Reprinted by permission of Bancroft Library, University of California, Berkely, from Stockman and Morris, 1887) 


\section{EDWARD S. MORRIS \& CO.}

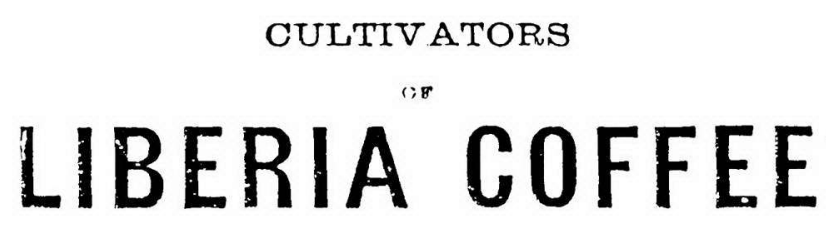

MANUFACTURERS

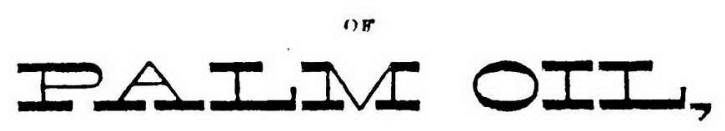

Indigo. LIME JuICE, ARrow Root.

AND

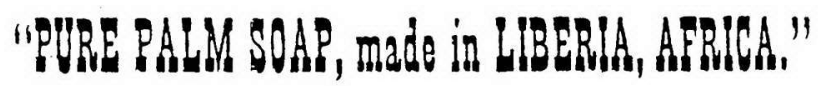

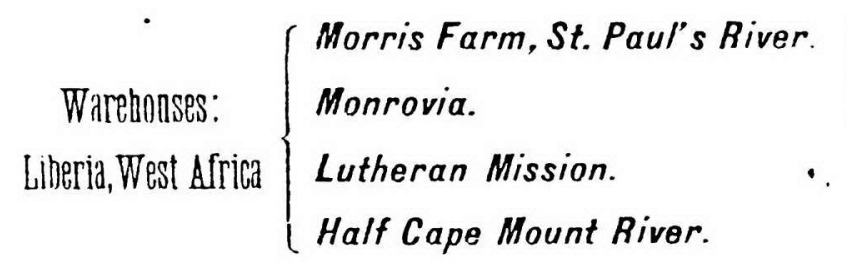

OFFICE:

No. 129 S. Front St., Philadelphia, Pa,

Figure 6: Morris' Store in Philadelphia (Reprinted by permission of

Bancroft Library, University of California, Berkely, from Stockman and Morris, 1887.) 


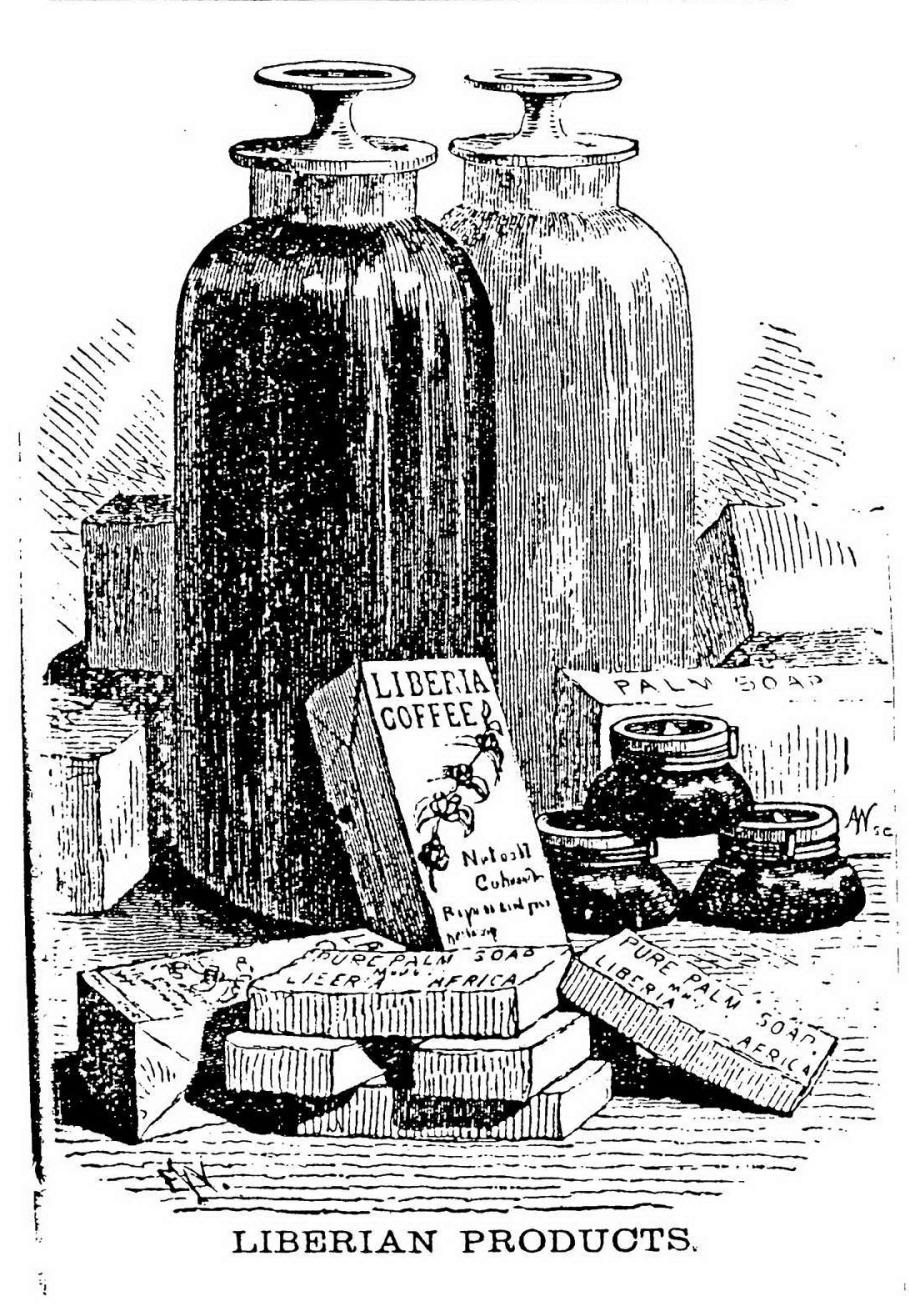

Figure 7: Liberian Products Palm Oil \& Palm Kernel In Round Glass Jars. (Reprinted by permission of Bancroft Library, University of California, Berkely, from Stockman and Morris, 1887) 


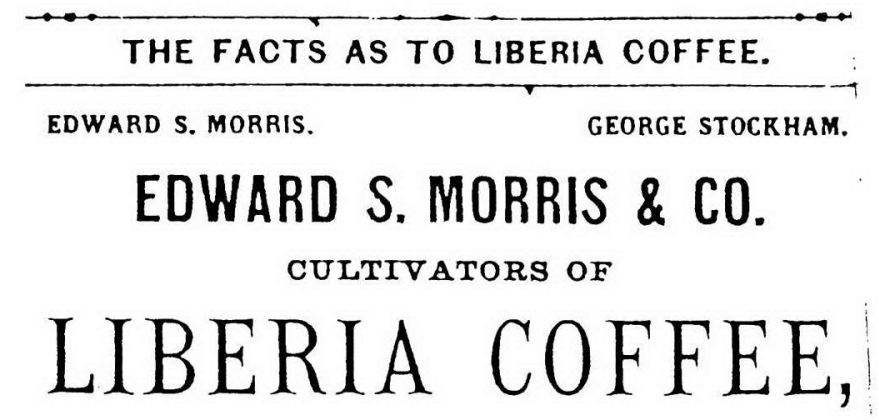

St. Paul's River, near Monrovia.

Office, 129 South Front St., Philadelphia, Pa.

LIBERIA COFFEE, pussisses all the strength of llio, and all the fine aroma of Java or Mocha Coffee. As it is hoth heavier and richer than either, less is requires to produce the usual quantity for drinking. Hence the

\section{U. S. Centennial Diploma Awards}

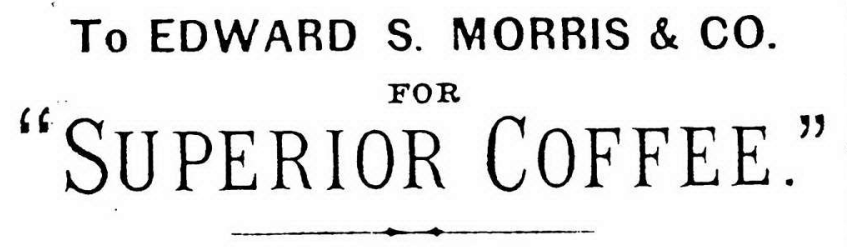

LIBERIA COFFEE, our own cultivation, ronsterl daily, and deliverenl tol any Expresa ('om. pany or Railroul station. $\Lambda l l$ in one pound air. tight parkages-parked in wood boxes containing fo or (1) lis. each.

Figure 8. Award for Superior Coffee. (Reprinted by permission of Bancroft Library, University of California, Berkely, from Stockman and Morris, 1887) 


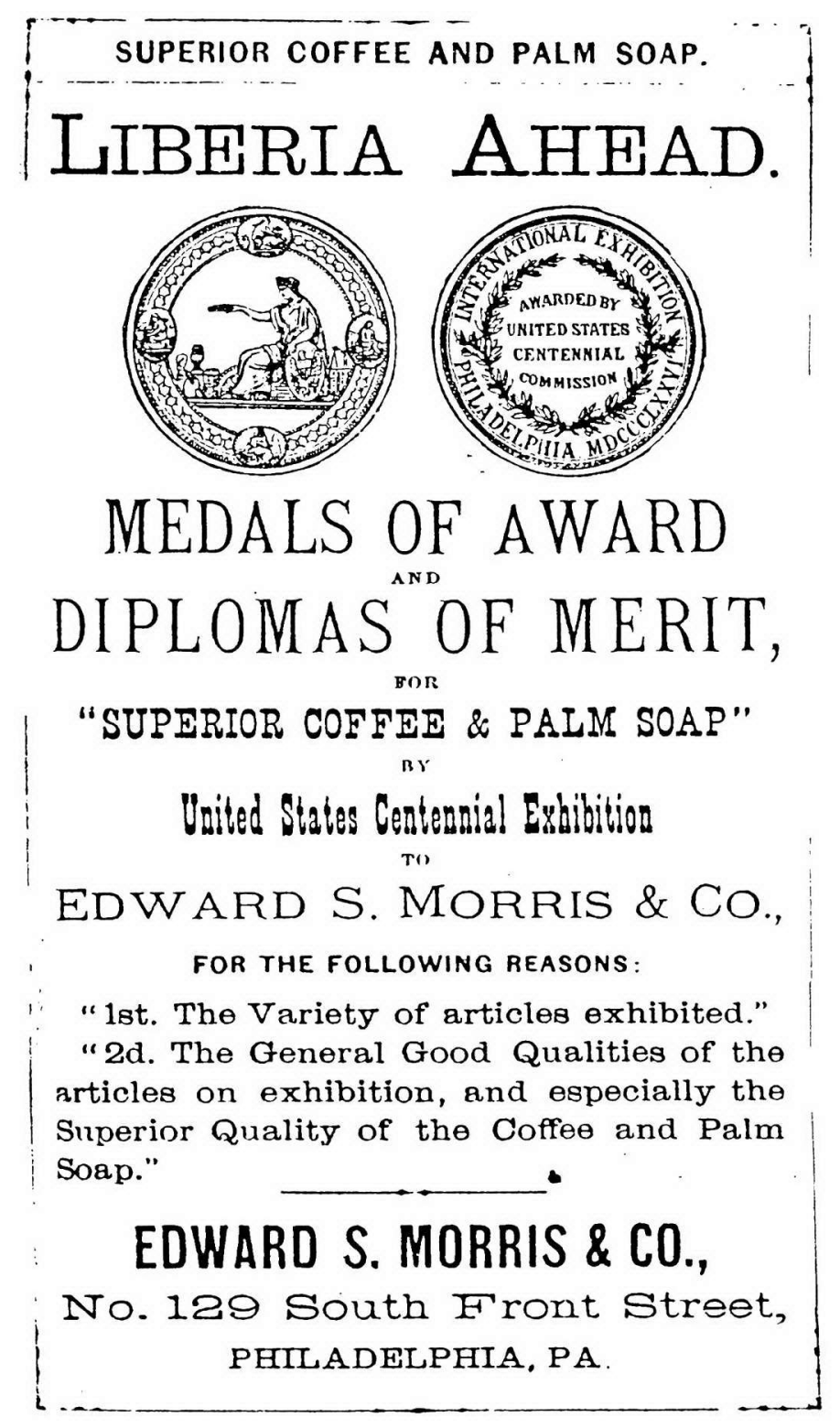

Figure 9. Award: Superior Coffee and Palm Soap.(Reprinted by permission of Bancroft Library, University of California, Berkely, from Stockman and Morris,1887) 
The greatest honor conferred on the Liberia coffee came from outside the United

States. During the month of the Exhibition in 1876, the Liberian coffee had been featured in a London magazine or journal, called "The Popular Science Review." The magazine revealed that in April of that year, the Linnean Society had assigned a "technical description" to the Liberian coffee. As previously noted, the "technical description" was the scientific nomenclature, Coffea liberica. ${ }^{45}$ Almost suddenly, the Liberian coffee ascended the top of the coffee market. In September of 1876, the London African Times published a letter, which among things, extolled the superior qualities of $C$. liberica:

It used to be supposed that of the known species but one, Coffea Arabica, possessed valuable properties, and it is this plant which yields those immense quantities of coffee which are required for the world's consumption. But it is not likely that it will continue long to monopolize ... for the Liberian kind possesses recommendations which cannot fail to induce its extensive cultivation, sooner or later. . . Mr. Cruwell, ... made the important statement ... that an estate of twenty or thirty acres well looked after would yield as much coffee as one of two or three hundred acres planted with Coffea Arabica ... and in point of favor they are said to be greatly superior. ${ }^{46}$

Coffee growers in Asia, the Caribbean and Latin America would begin to replace their local species with $C$. liberica. In the United States plans were made to cultivate $C$. liberica in "Lower California and Florida."47

Edward Morris was directly involved in the cultivation of the coffee he so assiduously advertised. An amendment to the constitution in 1876, which removed the prohibition that forbade foreigners to lease or hold land in Liberia, allowed Morris and a number of whites to rent land for farming. The amendment called "An Act to encourage

\footnotetext{
${ }^{45}$ The Popular Science Review, London, July 1876, quoted in Stockham and Morris, Liberia Coffee, 12.

${ }^{46}$ The (London) African Times, 16 Sept. 1876, quoted in AR, 1877, 21-23.

${ }^{47}$ Ibid.
} 
Agriculture and various products," allowed foreigners to rent lands "for from fifty to ninety-nine years for agricultural, business or commercial purposes, or for prospecting for minerals." ${ }^{48}$ Subsequently, Morris leased 800 acres of land on the St. Paul River for growing coffee. He regularly purchased coffee from local farmers at the highest market price. ${ }^{49}$ An analysis of the role of Morris and the ACS is the context of West African history is included at the end of this chapter.

\section{The Boom and the Decline 1870 s to 1890 s}

In March of 1881, Liberian immigrant Sherwood Capps sent a letter to his mother in the United States. He mentioned some personal details about his life: He had married, had a son, had built three houses, was teaching and farming and was "perfectly satisfied." Capps continued: "This a great coffee country. I have one thousand coffee trees under cultivation and expect to put out fifteen hundred more in September." ${ }^{50}$ Capps excitement about his coffee trees was representative of the general feeling in Liberia concerning coffee production. Coffee-growing had become the central occupation of a growing section of the Liberian population. This was the era of the coffee boom. It lasted until the 1890 s. By the end of the century, many of the farmers abandoned the crop because of declining prices.

Actually, the coffee prosperity had begun in the 1870s. During that decade, the price of coffee on the world market continued to rise and C. liberica was the celebrated

\footnotetext{
${ }^{48}$ Apkan, "The Liberian Economy," 20.

${ }^{49}$ Ibid., 18.

${ }^{50} \mathrm{AR}, 1882,36$.
} 
"new kid on the block." The fortune of the C. liberica rose even higher when it was reported to be resistant to the fungus that devastated coffee trees in Ceylon (home of the world famous Mocha coffee) and the other leading coffee-producing nations. ${ }^{51}$ The fungus was the "hemileia vastatrix," commonly called "rust" because of the rust-like stain that first appeared on the afflicted coffee leaf.

The coffee trees of Ceylon (the world-famous Mocha coffee) were among the first to fall to the "rust." Its coffee industry was totally devastated. Coffee growers in Ceylon began a desperate search for a resistant species to replace their ruined Mocha coffee. They ordered young sprouts of the C. liberica. In 1877 the African Repository published an excerpt from a British newspaper which revealed that the native Liberian plant had "taken root in the greatest coffee garden of the world, Ceylon." 52 Coffee growers in other nations also bought $C$. liberica for its alleged "rust" resistant quality. ${ }^{53}$

The seeming resistance of the Liberian coffee to the "rust," combined with its growing fame as a "superior" brand of coffee, resulted in a soaring demand for the Liberian plant. Brazilian planters ordered " 100,000 coffee plants and 50,000 pounds of seeds. ${ }^{, 54}$ Other New World producers, including Venezuela, South Australia, Jamaica and Costa Rica procured large quantities of seedlings of $C$. liberica ${ }^{55}$ In 1878 , the London Telegraph reported a sale at Cape Palmas in Maryland County (Liberia): "The

\footnotetext{
${ }^{51}$ Pendergrast, Uncommon Grounds, 42-43; Wickizer, The World Coffee Economy, 27.

${ }^{52}$ The (London) African Times, 16 Sept. 1876, quoted in AR, 1877, 21.

${ }^{53}$ Pendergrast, Uncommon Grounds, 44; AR, 1880, 6.

${ }^{54}$ Annual Report, 1879, 11.

${ }^{55}$ Philadelphia Times, (n.d.), quoted in AR, 1880, 6-7.
} 
market at Cape Palmas had just been cleared of all the coffee for sale by an American, who bought it at 22 cents ... per lb., an advance of upward of 50 per cent in value in a quarter of a century. ${ }^{56}$

Meanwhile, Liberians continued to make efforts to expand coffee production at home and abroad. One planter won an international award that also helped to enhance the fame of the Liberian coffee. The farmer was M. J. Decoursey, the enterprising sugar cane planter I referred to in the last chapter. In 1876 Decoursey was awarded a prize from James Irvine, the "leading African merchant in Liverpool." The prize was awarded "for the best growth of Liberian coffee during the season of 1876." ${ }^{57}$ Mr. Irvine, the Liverpool merchant, requested that the contestants (all Liberian coffee growers) submit "a ton of the best Liberian coffee," which would be examined by "two competent judges in Liverpool." Decoursey's coffee was selected as the winner and he was presented $£ 20$ (which was equivalent to about $\$ 100$ at the time) and a " medal in solid silver." Mr. Irving had instructed the workman in Liverpool to inscribe the medal with the words from Proverbs 28:19: "He that tilleth his land shall have plenty of bread." 58 Decoursey did have "plenty of bread"; he became one of the richest farmers in Liberia in the last three decades of the century.

To encourage citizens to grow coffee, the Liberian Government reintroduced the premium system. Monetary rewards were given to farmers who planted a specific number of coffee trees. For example, farmers with 10,000 new coffee trees could receive

\footnotetext{
${ }^{56}$ The London Telegraph, (n.d), quoted in AR, 1878, 12-13.

${ }^{57}$ lbid., 1877, 25.

${ }^{58}$ Ibid.
} 
a premium of $\$ 100 .^{59}$ There is a mixed reaction as to whether the premium system actually contributed to the expansion of coffee. According to The New Era newspaper, the premium system was "highly beneficial both to the country and ... acted as a powerful stimulus to industry and profit." ${ }^{60}$ But the newspaper later noted that "many citizens" saw the premiums as a "waste of public money on the farmers." Some farmers, the newspaper observed, abandoned the young coffee "scions" after collecting the reward thus, allowing the bush to reclaim the trees. ${ }^{61}$

Another government policy that was intended to encourage investment in coffee production was the Act to lease lands to foreigners, which made it legally possible for the American, Edward Morris to open a coffee plantation in Liberia. It was reported in 1878 that "a number of Europeans have leased lands on the St. Paul's river for coffee cultivation, and property there has risen in market value." ${ }^{, 2}$ Coffee farmer Allen B. Hooper, described in 1852 as the "systematic" farmer, appeared to have benefitted from the Act to lease land to foreigners. In the following excerpt from his letter, Hooper stated that

I have leased my land to an English Company to plant coffee in co-partnership. They bear all expenses and pay me $£ 60$. $(\$ 300$.) a year to oversee the work, and one- fourth of all the coffee we raise on my land. I want to put out one hundred thousand coffee trees within the next two years. The people of this country are getting along very well. They are planting coffee. This country in twenty years more will be one of the great coffee markets of the world. ${ }^{63}$

\footnotetext{
${ }^{59}$ The New Era newspaper, 24, September 1874, quoted in AR, 1874, 369.

${ }^{60}$ lbid.

${ }^{61}$ Ibid.

${ }^{62}$ Ibid., 39.

${ }^{63}$ Ibid., 1878, 38.
} 
Perhaps it was the success of the new law (or prospects of success) that motivated some citizens to propose further change in the constitution in 1877 . The proposed change was intended to permit whites to become land owners in Liberia and subsequently, citizens. But in the end, the majority rejected the amendment. ${ }^{64}$

\section{The St. Paul Coffee Settlements}

As the 1870 s drew to a close, coffee farming reached an unprecedented level. The ACS made the following observation in 1878: "The last crop was the largest ever known, 90,000 pounds of which were brought to New York in May, commanding some $\$ 22,000$." 65 The bulk of the coffee that was produced in this period came from the settlements of the St. Paul, in Montserrado County. For instance, in 1879, one settlement in the St. Paul, called Arthington, cultivated 463 acres of coffee. ${ }^{66}$ At 300 trees per acre, the total number would have equaled 138,900 trees. ${ }^{67}$ This was astounding accomplishment for a single settlement, considering that in 1863 all the leading coffeeproducing settlements of the St. Paul reported a relatively trifling total of 32,800 coffee trees or 109 acres. Clay-Ashland was another leading producer of the St. Paul, cultivating significant quantity of coffee for export. However, in 1874 The New Era newspaper

\footnotetext{
${ }^{64}$ Ibid.

${ }^{65}$ Annual Report, 1879, 11.

${ }^{66}$ Svend E. Holsoe and Bernard L. Herman, A Land and Life Remembered: Americo-Liberian Folk Architecture (Athens: University of Georgia Press, 1988), 10.

${ }^{67}$ The number of trees per acre varied. One source, for instance, noted that it was 300 trees per acre, another 500 trees. AR. 1886, 71; AR \& CJ, 1841, 198.
} 
seemed a bit hesitant to accept the claim that Clay-Ashland cultivated "two-thirds" of all the coffee that was shipped abroad. ${ }^{68}$

Brewerville, a settlement near the St. Paul and about 20 miles from Monrovia, was another coffee center. Sherwood Capps, whose correspondence was cited earlier, resided in Brewerville. Established in 1870, the settlement was named for Charles Brewer of "Pittsburgh, a large benefactor to the Society [ACS]." ${ }^{\prime 99}$ A total of fifty-eight immigrants from Martin County in North Carolina and Pennsylvania were the first to settle Brewerville. ${ }^{70}$ In 1873 John B. Munden, leader of the first group of immigrants wrote: "When I came to this country I was not worth fifty dollars. My assessment now is three hundred dollars. I am cultivating land in coffee ..." ${ }^{71}$ By the 1880 s, coffee farming was the major economic activity in Brewerville:

I was glad the find that the stoppage of immigrants to Brewerville has had no other effect than to stimulate the settlers. They are now farming in earnest. Their coffee plantations are making large and permanent inroads into the forest. Bissel, Banks, William Hayes, Batese, Lucas, are among the enterprising ones who are pushing forward the interests of the settlement, with an unwavering belief that the country is theirs, and that they belong to the country. ${ }^{72}$

One Brewerville farmer, who apparently prospered from his coffee farm and was convinced that he "belongs" to Liberia, was J. G. Sears. In 1891, Sears mentioned that he expected approximately 300 pounds of coffee from his farm and "a much larger

\footnotetext{
${ }^{68}$ Ibid., 1874, 369.

${ }^{69} \mathrm{AR}, 1873,350$.

${ }^{70}$ Ibid.

${ }^{71}$ Ibid.

${ }^{72}$ Annual Report, $1889,4$.
} 
amount the next season." ${ }^{.73}$ He then confidently asserted that he "would not go back to live in the United States." 74

Of all the settlements on the St. Paul, Arthington received the highest commendation for coffee production in the $1880 \mathrm{~s}$ and $1890 \mathrm{~s}$. The settlement was established by three small, successive waves of immigrants from the United States. The first immigrants arrived in 1869 in the ship Golconda with 160 passengers on board. Seventy-nine of the immigrants, from Bertie County in North Carolina, were the pioneers of Arthington. ${ }^{75}$ The next year the Golconda disembarked in Monrovia with 194 passengers, one hundred and twenty-five of which were designated for Arthington. ${ }^{76}$ The last group disembarked in Liberia in 1871 on the ship, Edith Rose. All, except three of the 243 passengers on the ship, were selected for Arthington ${ }^{77}$. A total of approximately 494 colonists finally settled in Arthington. The settlement got its name from Robert Arthington of England who donated the equivalent of " $\$ 5,000$ " to the ACS. ${ }^{78}$

Many of the new immigrants began to grow coffee almost immediately. By 1873 , most of the prominent citizens of Arthington were coffee farmers. That year the African Repository reproduced a brief account on the progress of agriculture in Arthington from The New Era newspaper:

\footnotetext{
${ }^{73}$ Ibid., 1892, 6.

${ }^{74}$ Ibid.

${ }^{75} \mathrm{AR}, 1869,366-369$.

${ }^{76}$ Ibid., 1870, 373-377.

${ }^{77}$ Ibid., 1871, 355-360.

${ }^{78}$ Ibid., 1873, 350.
} 
These people are not known to have brought to the country any capital except a determination to work ... For example, Mr. Hoggard has had no assistance from native boys, no aid but four small sons, and with them alone he has planted out five thousand coffee trees ... Mr. York ... has nearly three thousand trees growing, many bearing ... Mr. Jefferson Bracewell ... with the aid of his seven sons, he has cleared up more than thirty acres of land, planted eleven hundred coffee trees ... He has made a large coffee nursery ... Mr. Solomon Hill and Mr. June Moore ... have each planted seven hundred coffee trees, a large coffee nursery ... Mr. June Moore ... seems to vie with him [Hill] in industry in planting coffee and bread stuff. ${ }^{79}$

About four years later, Edward Blyden visited the coffee farms of Solomon Hill and June Moore and from his description, the "coffee rivalry" between the men, alluded to in the quotation above, had intensified.

He reported:

On we went, plunging again into the deep forest. Suddenly there broke upon our vision ... a large two-story frame building ... and all around outside the fence, as far as we could then see, were coffee trees ... a magnificent coffee orchard, in a high state of cultivation,... The heavy forest through which we had just passed terminates on the brow of a hill, which commands a view of the northern end of Arthington, taking in Sol. Hill's and June Moore's coffee farms. . . Mr. Hill has now 9,500 coffee trees in a place where four years ago, stood a dense forest; and he makes an independent living. ${ }^{80}$

In less than a decade, Arthington had become a predominant coffee settlement.

This was an astonishing achievement for the community. Svend Holsoe and Bernard Herman (authors of "A Land and Life Remembered"), who reported the 463 acres of coffee in Arthington in 1879, expressed their admiration for the settlers in this passage from their work:

By 1879 , when a census was taken of the Arthington community, there were 292 inhabitants, and 463 acres were under cultivation, a remarkable feat considering that the farm work was done by hand without any traction animals ... Although

\footnotetext{
${ }^{70}$ The New Era, (n.d.). quoted in AR $, 1873,338-339$.

${ }^{80} \mathrm{AR}, 1877,92$.
} 
there were indigenous Africans in the neighborhood, they were not interested in doing that kind of work; even if they had been, the wages were insufficient for the amount of labor involved. ${ }^{81}$

Arthington continued to forge ahead in the world of coffee in the 1880s and 1890s. The farmers continued to sell coffee overseas. In 1879 a group of farmers exported "nearly two thousand pounds for sale in New York." By 1887, Hill and Moore (the coffee rivals) cultivated about 10,000 pounds of coffee, while John Mills produced the same quantity in 1891. And about three years later, Mills alone harvested 18,000 pounds of coffee. ${ }^{82}$

\section{The Other Coffee Regions}

Although aside from Montserrado County (i.e., the St. Paul) coffee was cultivated in the other political subdivisions, the quantity produced in the remaining four counties was very sparse throughout this period. The fact that Grand Bassa County (specifically Edina, Bassa Cove and Bexley) is scarcely mentioned in archives in regards to coffee production after the 1860 s, suggests that the region never regained its pre-1870s eminence. There is an account, however, of coffee cultivation in a number of small settlements on the Farmington River in Grand Bassa County. The Farmington River is located about 40 miles southeast of Monrovia near Buchanan, the capital of Grand Bassa. Although not very much is known about the coffee farms on the Farmington River, a brief account is found in a letter of July 3, 1873. Jas. [James] H. Deputie, a member of the Farmington community, wrote the letter that was published several months later in the

\footnotetext{
${ }^{81}$ Holsoe and Herman, A Life and Land Remembered, 10.

${ }^{82}$ Ibid.
} 
African Repository under the title, "A Voice From Farmington River." He began the letter with the following remarks:

Hearing what the people are doing in the way of farming in other parts of the Republic has acted as a kind of stimulus upon our people here, and there is a spirit of "go ahead" exerted ... There has been a greater demand for coffee scions this season than there has been since I have been living here ... the people are giving some attention to the cultivation of this valuable plant. ${ }^{83}$

Deputie went on to give the names of the coffee farms. The farm where he lived was called Mount Olive. Reverend T. E. Dillon was the owner of the next farm, "Hope Dale Plantation." After Dillon's was the plantation of H. D. Brown. Its colorful name, "I Ran I Stand," leaves a lot to the imagination. S. J. Goolsby's "Palm Grove" were the "finest in the neighborhood." J. P. Artis' "Owen Grove" was the next farm. Artis was replanting coffee trees because a recent fire had destroyed his farm. Deputie concluded the description of the Farmington coffee farms with this statement:

Superintendent Davis has made a start in our neighborhood, and is engaged in the cultivation of the coffee and palm tree. Further down the river are farms owned by Mathis, Williams, and Page, who are engaged in cultivating coffee, \& c., and many of their coffee trees are bearing. ${ }^{84}$

Deputie's terse narrative does not reveal much about coffee farming at the

Farmington River. He does not indicate the number of trees or acres that were planted with coffee. Neither does he say how many immigrants lived on the various farms. Nevertheless, the narrative demonstrates that some of the smaller, lesser known immigrant communities, were also actively involved in coffee farming.

\footnotetext{
${ }^{83} \mathrm{AR}, 1873,333-334$

${ }^{84}$ Ibid., 334.
} 
There are also brief accounts about coffee cultivation in the remaining three counties. In Grand Cape Mount County (i.e., Robertsport, the principal town), an immigrant wrote about his coffee farm. Like the preceding story on the Farmington coffee farms, not much is revealed in the letter from Cape Mount. The immigrant, Wesley Blake, stated in 1891 that he had "5,000 coffee trees, out of which some 1,500 are bearing. ${ }^{85}$ From Sinoe County, John B. Pinney, a former Governor of Liberia (18341835) gave this account in 1877 :

Rev. Mr. Priest, from Sinou County, came up yesterday in fine health ... He says the soil in Sinou produces much larger crops than the land in this region [St. Paul]. He has many coffee trees yielding nine pounds at a crop. ${ }^{86}$

Nine pounds of coffee per tree was approximately two times the amount that was obtained from most trees in Liberia. ${ }^{87}$ The nine-pound yield is proof that Sinoe had the potential to produce significant quantity of coffee. Evidence of coffee production in Maryland County for the latter part of the century is equally scarce, but there are some indications that the settlers did grow coffee. For instance, the story in the London Telegraph of 1878 , which was previously cited, named Cape Palmas in Maryland as the place where the American "cleared all the coffee for sale." Additionally, this passage from the letter of Rev. C. C. Hoffman, of Cape Palmas proves that coffee thrived in the region: "In my last letter I mentioned ... I found the finest kind of coffee growing wild in

\footnotetext{
${ }^{85}$ ACS, 1892, 5-6.

${ }^{86} \mathrm{ACS}, 1877,11$.

${ }^{87}$ AR, 1880, 27; Ibid., 1882, 120.
} 
the woods ... But more attention has been paid to it in the settlements since your visit than ever before." 88

St. Paul's dominance in coffee in the last third of the century raises the question, once again, about the necessity of capital and equipment in commercial agriculture. As was indicated, the major equipment that the coffee farmers needed was the mechanical huller. Edward Morris sent a coffee huller to Liberia in the early 1870 s. In all likelihood, Morris installed his huller on his coffee plantation at the St. Paul or nearby in Monrovia. It is uncertain from the sources if additional mechanical hullers ever became available to planters in the other counties, aside from the locally-assembled huller in Grand Bassa that belonged to President Stephen Benson that was alluded to earlier. What is certain is that the farmers of St. Paul had access to Morris' hulling machine. If the only coffee huller were stationed in Montserrado County, this would explain why the other counties (in spite of the favorable reports about soil and climate) remained largely on the sidelines during the coffee boom.

\section{The Indigenous Coffee Farmers}

There is some proof, albeit scanty, that the indigenous people were also involved in the cultivation of coffee. One way in which the indigenous people participated in coffee production was through education and training. For example, the American Lutheran Mission School near Arthington, called Muhlenburg (established in the early 1860s) was an institute for training both Americo-Liberians and indigenous students in

\footnotetext{
${ }^{88}$ Ibid., $1865,184$.
} 
the rudiments of Christianity and agriculture. An account of the school is provided by Edward Blyden who served occasionally as a correspondent for the African Repository. According to Blyden, in 1887 the Muhlenburg institute had a total enrollment of seventy-three boarding students or "scholars" as they were called. Sixty of the scholars were boys and thirteen were girls. Fifty-eight of the scholars were selected mostly from the indigenous population in the region. ${ }^{89}$ The students learned to cultivate coffee, grow sugar cane and manufacture sugar. ${ }^{90}$ Bylden reported that "there are on the Muhlenberg grounds 25,000 coffee trees, which will yield this season about 16,000 pounds of coffee $-10,000$ of the trees are young and not yet bearing." 91 The mission was equipped with a coffee hulling machine and probably a steam sugar-cane mill. Blyden wrote that the huller cleaned " 500 pounds of coffee and 12 bushels of rice . . in a day" while " 1,000 pounds of sugar and 200 gallons of syrup" were manufactured. Blyden added that all the work was done by "the natives" who would be "fully competent to transfer some of the things they have learned to their country, and in such a way that their people easily lay hold of them." ${ }^{92}$ The widespread diffusion of coffee culture among the indigenous people of the Liberian interior in the twentieth century, most certainly had its genesis in the

\footnotetext{
${ }^{89}$ Ibid., 1887, 61 .

${ }^{90}$ Ibid.

${ }^{91}$ Ibid.

${ }^{92}$ Ibid.
} 
acculturation that the "natives" received at socio-cultural institutions such as the Muhlenburg Station. ${ }^{93}$

A second way in which coffee expanded among the indigenous people was through the apprenticeship system employment. In the apprentice system, indigenous youths that were wards of Americo-Liberian coffee farmers learned how to grow the crop. Blyden recorded one incidence between the wealthy farmer, Solomon Hill, and two of his wards from the Kpelleh ethnic group: "His influence upon the Aborigines has been most wholesome. Two of the native youth trained by him (Pessehs) are now their own masters, and have their coffee farms ... cultivating from thirty to fifty acres of land." The Kpelleh youths did not only learn to grow coffee in the "MericaMantown," as the local people referred to Americo-Liberian settlements. One of them "married a highly esteemed colonist, widow of one of the late prominent settlers." ${ }^{94}$ Finally, indigenous men, who were employed on the coffee plantations of the Americo-Liberians, could acquire the knowledge for cultivating coffee.

While "all classes" grew coffee in the last decade of the century, $C$. liberica had lost considerable appeal on the international market. In the 1890 s, the price of coffee, which had been as high as 24 cents and 25 cents a pound, in the previous decades, began

\footnotetext{
${ }^{93}$ By the 1980s and prior to the Civil War of 1989 to 1996 , coffee was one of Liberia's principal agricultural export commodities. It accounted for a substantial portion of the annual gross domestic product. All of the coffee is cultivated in the more forested regions of the interior. Indigenous farmers not only do the bulk of the work, but some of the wealthier indigenous farmers own large farms, especially in Lofa County. For details on coffee farming in the twentieth century see the following: Timothy R. Frankenberger, et al., Farming Systems Research in Three Counties in Liberia: A Reconnaissance Survey in Grand Gedeh, Nimba and Bong Counties (University of Florida, 1985); Theodore Jenne, Agriculture in Liberia: Realities, Problems and Potentials (HRSG.: Institut Für Regionalwissenschaft Der Universität Karlsruhe, 1982); The Ministry of Agriculture, Liberia, The Liberian Farmer, 3, 1(1998).

${ }^{94} \mathrm{AR}, 1889,45$.
} 
to plunge. So rapid was the decline in price that in 1898 and 1899 a pound of coffee sold for less than 10 cents. ${ }^{95}$ The problem that plagued $C$. liberica in the 1890 s can be traced back to the 1870s and afterward when the better-financed coffee planters in Latin America began to modernize their equipment and subsequently improved the quality of coffee beans that they sold overseas. Liberian coffee growers could not match the higher quality of coffee that their competitors offered to consumers in the United States and England. As a result, coffee buyers showed less enthusiasm for the once "superior" $C$. liberica. A detailed analysis of the causes for the decline is presented in Chapter VI.

\section{The Comparison}

There are some striking similarities and differences in the history of Liberia's two principal agricultural exports. The first similarity centers on the impact that capital and equipment had on both industries. One factor that contributed to the coffee boom was the availability of the coffee huller. From the 1850 s to the 1860 s, when the farmers did not have access to the huller, they exported less than 50,000 pounds of coffee. In 1885 alone, with the availability of the huller, the planters sold approximately 800,000 pounds overseas. ${ }^{96}$

It is evident that the huller made a significance difference. Prior to the advent of the huller, Abraham Hanson, the United States Representative in Liberia, explained why the machine would stimulate coffee farming:

Coffee bids fair to become the basis of many an independent fortune. It is cultivated with ease, and with comparatively small expense ... The entire lack of

\footnotetext{
${ }^{55}$ Annual Report, 1900, 9.

${ }^{96}$ Akpan, "The Liberian Economy," 21.
} 
suitable machinery for hulling has, heretofore, deterred many from engaging in this branch of agriculture. ${ }^{97}$

The huller eliminated two of the most time-consuming and arduous tasks. The first was removing the hulls from the coffee berries and then separating the beans from hulls. Not only was the manual process of hulling the coffee-pounding the dry berries in a mortar with a pestle-tedious, but it resulted in the loss of coffee beans and ultimately reduced the farmer's profit margin. When pounding the berries, some of the clean coffee beans were crushed and mashed. As a consequence, the farmers were compelled to sell the crushed beans at a discount of about 50 percent. ${ }^{98}$ In a sense, the huller restored the 50 percent of the crop and saved time in the process. The machine could hull and clean a bushel of coffee in about three minutes. ${ }^{99}$ This was far less time than any human power . could ever accomplish. The second advantage of the hulling machine was that it graded the coffee beans into a variety of sizes before they were finally exported. Grading was essential because it could influence the price of the coffee. ${ }^{100}$

A few years before the huller was shipped to Liberia, someone predicted at the time that it would create "revolution in the coffee trade." 101 It did create a revolution, particular on the St. Paul. This following remarks by the Farmington settler, James Deputie in 1878 or late 1877 , attested to this: "The coffee huller is providing a blessing to

\footnotetext{
${ }^{97} \mathrm{AR}, 1866,66$.

${ }^{98}$ Ibid., 1874, 369.

${ }^{99}$ Ibid., 1876, 116-117.

${ }^{100}$ V. D. Wickizer, The World Coffee Economy, 43.

${ }^{101}$ Ibid., 1873, 21.
} 
Liberia, and will soon make Africa a coffee grove." ${ }^{102}$ The coffee huller did for coffee farmers what the sugar cane mills accomplished for sugar manufacturers.

Another commonality between the coffee and sugar industries has to do with the social class of the farmers. I presented evidence that demonstrated the sugar manufacturers were members of the upper echelon of the Americo-Liberian society, who were largely educated. The same can be said—in regards to education —-for the nine successful coffee farmers that I have identified: Allen Hooper, Stephen Benson, M. T. Decoursey, Jefferson Bracewell, June Moore, Solomon Hill, John Mills, John Munden and J. G. Sears. Seven of the nine men were literate, while two, Hills and Mills were non-literate. ${ }^{103}$ So, just like the sugar manufacturers, the coffee farmers were from the very small class of elite in the Americo-Liberian community. They were educated and very likely, most lived above the means of the average settler. It was noted that one planter, Stephen Benson, even ascended to the high office of President of Liberia.

The main difference between the sugar and coffee industries that I have considered is the number of planters in each sector. There were less than a dozen sugar manufacturers. No figure can be given for coffee because the data is sparse. However, the scattered pieces of evidence in the archives do confirm that a larger number of people, "all classes," did cultivate coffee. At the beginning of this chapter, I explained that the Americo-Liberians generally agreed that the cultivation of coffee was far less capitalintensive than manufacturing sugar. The difference in cost helps to explain why more

${ }^{102} \mathrm{AR}, 1878,29$.

${ }^{103}$ The references for Decoursey, Hooper President Benson were cited earlier. For the rest of the men, see, AR 1869, 366-369; Ibid., 1870, 373-377; Annual Report, 1892, 6. 
settlers turned to coffee. This action by the settlers demonstrates their willingness to become farmers. While a large number of the settlers with capital continued to invest in trade in the second half of the century, others were willing to invest in commercial agriculture. Some had the capital but did not invest in commercial agriculture. Their noninvolvement was not due to a disdain for farming as it is commonly assumed. In most instances, Mother Nature (i.e., malaria) had more to do with that decision than the individuals themselves. The role that the tropical Liberian environment played in commercial agriculture, is the focus of the next chapter. But first, I will attempt to analyze the underlying motives behind Edward Morris' philanthropy.

\section{Edward Morris: Philanthropist and Colonizer}

The label "merchant and philanthropist," which is sometimes used to describe Morris, is rather simplistic and does not fully explain the underlying motives behind his benevolent deeds and commercial activities in Liberia. ${ }^{104}$ Morris' goal for education was published in the African Repository of 1880, under the caption "A Bright Spot Upon a Dark Country." An excerpt from the article points to Morris' objective:

Concerning the proposed school house in Liberia, Mr. Morris needs but $\$ 2,500$ more to make his fund sufficient ... it is intended especially for the education of sons of native African chiefs, especially those in the rear of Liberia and in the Niger valley, hoping in due time to reach the heart of Soudan, where it is said there are fifty millions of ready to_be fashioned in the ways of civilization and Christianity. ${ }^{105}$

Morris' goal for education in Liberia indicates that he was not merely interested in commerce and philanthropy per se. His desire to mold Africans in "the ways of

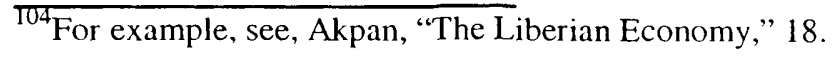

${ }^{105}$ Ibid., 1880, 7.
} 
civilization and Christianity," suggests an ideological motive that inspired him to labor for the advancement of commerce in Liberia. He, along with Henry Schieffelin and others "friends of Colonization," who arranged credits for sugar cane farmers, played a much more complex role in Liberian history in the nineteenth century. ${ }^{106}$ Like European missionaries and explorers in Africa in the nineteenth century (e.g., David Livingstone and Henry Stanley), Morris represented a specific school of thought in regards to African colonization. These men believed, among others, that Africans and their way of life was inherently inferior, and only through the medium of Western "civilization and Christianity" could Africa attain economic development and cultural advancement. Morris, along with the explorers and the missionaries in Africa, was opposed to the slave trade. These people believed that the trade in human cargoes was evil and wasteful. As abolitionists, the men directed their attack on slavery mainly at the source of the commerce, in Africa. They were convinced that if Africans could be persuaded not to sell captives to European slave buyers, the source of the supply would eventually dry up. To accomplish their goal, the abolitionists adopted a two-pronged plan. They would introduce other forms of commerce to Africans as a substitute for the trade in slaves. This commerce would rest basically on the cultivation of agricultural staples, such as coffee and cotton, for export to Europe and the United States. Free blacks in England and the United States were to be encouraged to return to Africa and cultivate the tropical staples. Abolitionists were certain that Africans would ultimately abandon the slave trade because they would realize the benefits of commercial agriculture and Christianity. The expression "legitimate trade" came to represent the new commerce.

${ }^{106} \mathrm{AR}, 1859,248 ; \mathrm{AR}, 1891$. (Page number illegible.) 
When one considers the goal of the abolitionists, it seems that they were motivated by the strong moral conviction that slavery was an inhumane system. The solution for ending the evil, that is legitimate trade, appears to be equally driven by humanitarian concerns. For instance, Thomas Buxton the British abolitionist and the chief architect of the concept of legitimate commerce, was renowned for his unwavering condemnation of the "horrors of the Slave Trade ... and the waste of human life which accompanied it."107 Buxton claimed that the legitimate trade, "would put down the Slave Trade, by demonstrating the superior value of man as a labourer on the soil, to man as the object of merchandise." ${ }^{108}$ Thus emancipation was portrayed, according to historian Bill Freund, as "a paternalist symbol of European moral superiority and good will."109

However, the moral motivation of Buxton and the other abolitionists, including Morris, comes into question when one recognizes that they tended to link the anti-slavery campaign to the exploitation of Africa's resources. Buxton wrote:

We may assume, and with the almost equal confidence, that Africa can never be delivered, till we have called forth the rich productiveness of her soil; . . . but for the Slave Trade, the other trade of Africa would be increased fifty or a hundredfold." 110

\footnotetext{
${ }^{107}$ Buxton, The African Slave Trade and its Remedy, $\mathrm{i}-\mathrm{ii}$.

${ }^{108}$ Ibid., 306.

${ }^{109}$ Bill Freund. The Making of Contemporary Africa: The Development of African Society since 1800 (Bloomington: Indiana University Press, 1984), 60.

${ }^{110}$ Ibid., 279, 303.
} 
Morris enjoined his Liberian audience, themselves descendants of slaves, to fight against the slave trade by becoming farmers. Coffee, he declared, would deliver "another blow to slavery."111

Eric Williams, the Caribbean historian and former President of Trinidad and Tobago, was one of the first to challenge the notion that British abolitionists were motivated by humanitarian concerns. Williams argued that the slave trade had been abolished basically for economic reasons. He contended that economic forces, like decreasing revenues from British sugar plantations in the West Indies, British industrial interests and the rise of capitalism, were the underlying motives for the abolition of the slave trade. ${ }^{112}$ An example of British industrial interests would be the raw materials, such as vegetable oils from Africa (e.g., palm oil), which were used to lubricate the wheels of European industrialism.

Critics have pointed out that Williams' thesis focused too narrowly on economic factors, while the advocates of the moral explanation for abolition, in the words of Anthony Hopkins, are "stronger on narrative than explanation." 113 The transition between the abolition of the slave trade and the exploitation of Africa's resources and colonialism is much too logical to be ascribed to happenstance. On the other hand, the humanitarian aspect of abolition must, nonetheless be acknowledged. By the nineteenth century, liberal ideas of egalitarianism or what historian Ralph Austen calls "secular enlightenment

\footnotetext{
${ }^{\Pi 1}$ Morris, "An Address Before the Liberia Union Agricultural Enterprise," 7

${ }^{112}$ Eric Williams, Capitalism and Slavery (New York: Russell \& Russell, 1961), 145-153.

${ }^{113}$ Hopkins, An Economic History of West Africa, 113; The literature on the debate about abolition is vast. In addition to Hopkins', see Roger Anstey, The Atlantic Slave Trade and British Abolition, 1760-1810 (London: Macmillian, 1975); Ralph Austen, African Economic History (London: James Currey, 1987); Freund, The Making of Contemporary Africa.
} 
philosophy" had effectively persuaded many that slavery was abominable. ${ }^{114}$ In the United States, it was the enlightened notion of equality (called revolutionary ideology), for example, that motivated Americans-initially Northerners-to denounce slavery and work for its abolition.

It is not difficult to realize that Edward Morris and his peers in the ACS truly believed that slavery was a reprehensible system. As indicated earlier, during the formation of the ACS, some supporters of the anti-slavery movement in the United States believed that colonization would eventually lead to the abolition of slavery. As Manager of the Pennsylvania Colonization Society, Morris worked diligently to encourage free blacks in the United States to emigrate to Liberia. In spite of his philanthropic motives, Morris was convinced that the place for the former slaves was not in the United States where the free blacks themselves believed they had far greater opportunity for economic advancement. For Morris and the other "philanthropists" of the ACS, it was in the interest of American capitalism for the former slaves to return to Africa and continue to produce staples like coffee, for their erstwhile masters in the United States.

${ }^{\Pi+}$ Austen, African Economic History, 111. 


\section{CHAPTER V}

\section{DISEASE, IMMIGRATION, AND ADAPTATION}

When I first went up the river to clear my farm, some days I could work but a few hours, on account of the fever and chills ...

-Richard Murray, Liberian immigrant. ${ }^{1}$

The emigrants number 25 . They have had no fever yet. They that remained at the river, are sick, and a number died-while those in the interior have no fever and are able to work daily in chopping and clearing off the land. This is indeed encouragement and cheering to the friends of Colonization.

-Chas. Deputee, Liberian immigrant. ${ }^{2}$

I intend to accomplish three objectives in this chapter. First, I will try to prove that the effects of malaria and the pattern of immigration contributed to a shortage of labor which ultimately hindered the development of commercial agriculture. My second goal is to demonstrate that in spite of the consistent efforts by the American Colonization Society and the farmers to introduce draft animals in Liberia for farm work, animal traction remained scarce throughout the nineteenth century. The scarcity of draft animals impeded the growth of commercial agriculture. The final goal is to demonstrate that the immigrants were able to adapt to the new environment. Adaptation was gradual, but it ultimately enabled the immigrants to overcome some of the obstacles that had earlier impeded the development of commercial agriculture.

\footnotetext{
AR \& CJ, 1845, 336

${ }^{2} \mathrm{AR}, 1857,169$
} 


\section{The African Fever, 1822 to 1847}

A study of the census of 1843 revealed that diseases killed a large percentage of the immigrants between 1822 and $1843 .^{3}$ Out of a total of 4,454 immigrants repatriated by the ACS, an estimated 2,198 or 49 percent died of various causes. ${ }^{4}$ The "African fever" accounted for the highest number of deaths: 845 or 38 percent of the mortality. Modern medical science has identified the African fever as malaria and yellow fever, both of which shared some common symptoms. ${ }^{5}$ The excessive death rate of the Liberian immigrants was an indication that West Africa, known by the nineteenth century as the “White Man's Grave," was even-handed in the dispensation of its pathogens to newcomers-whether they were white or black. ${ }^{6}$

The high death rate of the Liberian immigrants led historian Wilson Jeremiah Moses' to observe that the title of Antonio McDaniel's book, "Swing Low, Sweet Chariot" was a reference to the certain death that American immigrants faced when they relocated to Liberia. ${ }^{7}$ McDaniel himself stated that

The fact is that every aspect of the enslavement of Africans in the Americas had its price in African lives lost. For Africans who returned to Africa from North

\footnotetext{
${ }^{3}$ The Census

${ }^{4}$ Ibid.

${ }^{5}$ One of the shared symptoms of malaria and yellow fever is the recurring fever. See, Curtin, Philip Curtin, Death by Migration, McNeil, Plagues and People; R. Hoeppli, Parasitic Diseases in Africa and the Western Hemisphere; Kiple, Another Dimension of the Black Diaspora; Pampana, A Textbook of Malaria Eradication.

${ }^{6}$ See the following texts for the discussion on the subject of the "White Man's Grave." Philip Curtin, "The End of the White Man's Grave: Nineteenth-Century Mortality in West Africa" Journal Of Interdisciplinary History, 21, 1 (1990): 63-88; K. G. Davies, "The Living and the Dead: White Mortality in West Africa, 1732-1884," in Stanley L. Engerman and Eugene D. Genovese, ed. Race and Slavery in Western Hemisphere: Quantitative Studies (New Jersey: Princeton University Press, 1975): 83-98.

${ }^{7}$ Moses, Liberian Dreams, xxv-xxvi.
} 
America in the beginning of the nineteenth century, lives lost from disease-the "mortality cost"-meant a death rate substantially higher than that of their brethren who stayed in the United States. The bulk of this excess mortality occurred in the first year of residence in Liberia .... The differences between the mortality of the enslaved population in the United States and that of the Liberian immigrant population are the cost of immigration to Liberia. This is the cost in deaths of removing an African born in the United States to a new setting in Liberia. The cost of colonizing Liberia was extremely high. ${ }^{8}$

How did the high "mortality cost" affect sugar and coffee production in the period 1822 to 1843 ? The effects can be interpreted in several ways. I will consider two interpretations. First, mortality reduced the number of potential workers and entrepreneurs for the sugar and coffee industries. In the last two chapters, I cited sources that indicated the planters hired the poorer immigrants. The problem of labor was probably exacerbated since population did not increase during the period. ${ }^{9}$

Another way in which malaria affected agriculture was the lingering effects of the disease on survivors. Anthropologist Peter Brown, who conducted research on malaria, refers to the infection as the "great debilitator" because of its acute ability to enervate survivors. ${ }^{10}$ Brown noted that although as much as 80 percent of the population of Sardinia, Italy, was generally affected with malaria, "only 4 to $7 \%$ of the deaths were directly caused by the disease"11 The "low case-mortality ratio" of malaria is actually deceptive since the disease "saps the strength of a victim" resulting, for example, to

\footnotetext{
${ }^{8}$ McDaniel, Swing Low, Sweet Chariot, 125-126.

9Shick, "A Quantitative Analysis," 58-59.

${ }^{10}$ Peter J. Brown, "Malaria, Miseria, and Underpopulation in Sardinia: The Malaria Blocks Development Cultural Model," Medical Anthropology 17 (1997), 241.

${ }^{11}$ Ibid.
} 
"abortion in pregnant women"" and a greater "risk of low birth rate and infant mortality." 13

There is no medical evaluation of the census of 1822 to 1843 . Consequently, the exact causes of the deaths have not been established. It may never be known, for instance, if the 55 deaths attributed to "childbirth and female disease" in the census were malaria-related. ${ }^{14}$ Or how many work-hours/days were lost by the author of the first epigraph, who "could work but a few hours on account of the fever and chills?" Research conducted in the 1950s indicated that Liberians missed an average of 3 days in a year due to illness caused by malaria. ${ }^{15}$ An average of 3 out of 365 days would appear to be inconsequential. However, unlike Liberians in the 1950s, the immigrants did not have the immunity that stemmed from residing in the malarial environment for several generations. ${ }^{16}$ For the immigrants, the debilitation could be expected to be much more severe. Consequently, the total days lost from work by each sick immigrant would have been higher than the three days researchers recorded for the twentieth-century Liberians.

\footnotetext{
${ }^{12}$ Ibid., 241-242.
}

${ }^{13}$ Stanley O. Foster, "Malaria in the Pregnant African Woman: Epidemiology, Practice, Research, and Policy," American Journal of Tropical Medicine and Hygiene 55 (1996): 1. For a detailed discussion on malaria-induced diseases, see Pampana, Textbook of Malaria Eradication, Leon Warshaw Malaria: Biography of a Killer (New York: Rinehart and Co., 1949).

${ }^{14}$ The Census.

${ }^{15}$ Pompana, Malaria Eradication, 483.

${ }^{16}$ Medical research indicates that African Americans exhibit some form of resistance to plasmodium vivax," the milder strain of the malaria which was found in parts of the United States in the eighteenth and nineteenth centuries. P. vivax is reportedly uncommon in West Africa. The virulent strain, called plasmodium falciparum is said to be endemic to West Africa. For the medical research, see, Martin D. Young et al., "Experimental Testing of the Immunity of Negroes to Plamosdium Vivax, Journal of Parasitology 41 (1955): 315-318. And on the types of malaria, see, McNeill, Plagues and People, 29, Curtin, Disease and Empire, 5-6. 
Immigrant Henry Johnson, who was mentioned earlier, recalled that his family was enfeebled for "three years . . It was up to-day and down to-morrow" he wrote in $1870 .{ }^{17}$

\section{American Farmers Without Plows: "No animal labor to assist"}

Officials of the ACS and the settlers associated the success of commercial agriculture with the availability of animal traction. In 1840, for instance, Thomas Buchanan, the white American Governor of Liberia, wrote bluntly on the subject in his report to his bosses in Washington, D.C.:

There is no reason to expect that agriculture will thrive in Liberia without working animals, than in Iowa or Michigan, and if the settlers in the West had been compelled to collect the materials for their homes, clear the land and plant it by manual labor, we doubt whether they would have done more, than has been done in Liberia, and perhaps not so much. ${ }^{18}$

Letters written by some of the settlers also emphasized the need for working animals.

One newcomer wrote back to the United States in 1851 and stated that

The people are all farmers, and are men who have had to start with nothing and work their way upwards, and most notably have some of them done so; and farming here is different from what is in the United States. Every thing here has to be done by man; no animal labor to assist; though now there is a better prospect, as Seymour has broken a pair of oxen and there will soon be more. ${ }^{19}$

Another immigrant advised prospective colonists in the United States "to bring mules, horses ... and farming tools." 20

\footnotetext{
TTAR, 1870, 329.

${ }^{18}$ Annual Report, 1840, 23.

${ }^{19} \mathrm{AR}, 1851,268$.

${ }^{20} \mathrm{AR}, 1851,331$.
} 
The ACS and the settlers made efforts to procure draft animals. One of the

earliest attempts by the Society to provide animal traction to the immigrants is found in the African Repository and Colonial Journal of 1836. The Journal reported:

To promote this success by bringing into use the plough, harrow, and cart, the Society resolved at its last meeting, that such working animals as are best suited to a tropical climate should be introduced into the Colony. It being understood that animals raised in the Cape de Verde Islands were more suitable to it than those raised in the United States, a provision was inserted in the charter party . . . that the vessel should touch at those Islands, and take thence as many horses, mules, and asses. ..."21

The animals arrived and there was optimism in the Colony. A dispatch from Liberia in 1840 highlighted the enthusiasm and expectation:

The progress of agriculture in the Colonies, has been greater ... Several of the Colonists ... turned their attention to farming and commenced the use of working oxen. Fifteen mules, jacks, and mares were taken from the Cape de Verde to Liberia. .. and sold to the Colonists, and it is intended that an equal or greater number shall be sent out every voyage, until the Colony is fully supplied. ${ }^{22}$

Officials of the ACS encouraged farmers to use local oxen for farm work. In

1833 , the organization offered rewards to the first colonist who would "train cattle to labor, and use the plough in cultivation." ${ }^{23}$ By 1841 , cattle were being used because the Public Farm listed "2 Yoke of Oxen" in the Statistics. ${ }^{24}$ That same year it was reported that Governor Buchanan "provided working animals sufficient for the wants of all the Colonists" in Sinoe County. ${ }^{25}$

\footnotetext{
${ }^{2 \mathrm{AR}} \& \mathrm{CJ}, 1836,19$.

${ }^{22}$ Annual Report, 1840, 23.

${ }^{23}$ Ibid., $1833,5$.

${ }^{24}$ Ibid., $1841,37$.

${ }^{25}$ Ibid., 16.
} 
Despite these efforts, the need for working animals remained unfulfilled. In 1856 or 1857, a visitor to Liberia recorded the absence of animal traction in Liberia in his journal. He noted that "no horses, no mules, nor even donkeys and the oxen ... Farming by hand is slow ... where grass grows so rapidly.... The very fertility of the soil is a disadvantage with the present means of husbandry." ${ }^{26}$ Sion Harris, an immigrant wrote that the plows the ACS had sent to Liberia "are rotting; there has never been any use found for them before." 27 In 1850, Captain Andrew Foote of the United States Navy noted the scarcity of draft animals:

As oxen, horses, mules, or plows have not yet been introduced here to any considerable extent in agricultural operations, you can imagine it is no easy task to clear fifty acres of land, and prepare it for cultivation. Horses will not live on the seaboard, though they do well in the interior; but I have no doubt that these places might be well supplied by the elephant, if the people have the energy to catch and train them. ${ }^{28}$

More working animals were imported in the second half of the century. It was reported in 1864 that "about forty beasts of burden and draft have been introduced from the Cape de Verde islands," off the Western coast of Africa. ${ }^{29}$ Some of the immigrants continued to purchase cattle from the interior for draft. In spite of these efforts, animal traction was rarely used in Liberia in the nineteenth century. The comment by sugar manufacturer William Anderson that "I lack, as do also all my brother farmers, animals,

\footnotetext{
${ }^{26}$ Thomas, Adventures and Observations, 155.

${ }^{27} \mathrm{AR} \& \mathrm{CJ}, 1850,234$.

${ }^{28} \mathrm{AR}, 1851,220$.

${ }^{29}$ Annual Report, 1864, 6.
} 
or at least such as would better suit our purposes," was just as valid by the end of the 1800 s as it was in 1863 when he made it. ${ }^{30}$

History of the Animal Disease: Trypanosomiasis

Studies in veterinary science in the last century have help to explain the "disappearances" of the draft animals that were brought to Liberia. These studies suggest that the animals died from to a combination of disease and stress. The disease was trypanosomiasis or animal sleeping sickness. Under stressful conditions, the afflicted animals tended to succumb much easier to the disease. There are several species of trpanosomiasis that affect both humans and various domestic animals. The one that killed the horses and cattle is known as the Trypanosomiasis brucei gambiense or simply T. brucei. It is transmitted by one species of the tsetse fly (Glossina palpalis). ${ }^{31}$ In the horse, the disease is generally characterized by swelling of the abdomen, scrotum and legs. Hence, it was commonly called the "loin disease." Death followed shortly thereafter, usually "within two weeks to three months." 32

Although it was not until the twentieth century that medical science began to understand the causes of $T$. brucei, some Africans (especially pastoral groups in West Africa) have known for centuries that there was a relationship between the tsetse fly and the infection that killed their stock. ${ }^{33}$ According to Hoeppli, the West Africans were even

\footnotetext{
${ }^{30} \mathrm{AR}, 1863,29$.

${ }^{31}$ Ford, Trypanosomiasis, 448-449.

${ }^{32}$ D. C. Dorward and A. I. Payne, "Deforestation, the Decline of the Horse, and the Spread of the Tsetse Fly and Trypanosomiasis (NAGANA) in Nineteenth Century Sierra Leone," Journal of African History 16, 2 (1975): 243.

${ }^{33} \mathrm{R}$. Hoeppli, Parasitic Diseases in Africa and the Western Hemisphere, 37.
} 
aware that a disease similar to the sleeping sickness, which killed cattle and horses, was also fatal to humans. ${ }^{34}$ The human sleeping sickness, known by various names such as "negro lethargy" and the Sleepy Disease," was identified as Trypanosomiasis gambiense in the early 1900 s. $^{35}$

In West Africa, only two species of cattle, the humpless longhorn cattle called the N'Dama and the humpless shorthorn referred to in Nigeria as Muturu, have adapted to $T$. brucei. ${ }^{36}$ The robust zebu cattle (Bos indicus), used as draft animals in most parts of Africa, are susceptible to the infection. ${ }^{37}$ On the Liberian coast, it was the N'Dama, commonly called the "Liberian cattle," that thrived. ${ }^{38}$ The Liberian cattle or N'Dama from Guinea, called "Mandingo cattle" in Liberia, were trained for farm work.

In spite of the fact that the N'Dama cattle are resistant to T. brucei, they proved to be unfit for the tasks that were required of them. In 1842, Governor Joseph Jenkins Roberts of Liberia informed a Dr. Hodgkin about the problem:

It is difficult, in Liberia . . . to cultivate a farm to any considerable extent for the want of draft animals. The cattle on the coast are found to be small, and insignificant and not at all suited to the purposes of the farm. Those from the interior which are larger, when brought to the coast live but a short time. ${ }^{39}$

\footnotetext{
${ }^{34}$ Ibid., 31-32.

${ }^{35}$ Ibid., 38.

${ }^{36}$ Ibid.

${ }^{37}$ Ford, Typanosomiasis, 449

${ }^{38}$ George W. Brown, The Economic History of Liberia, 87.

${ }^{39} \mathrm{AR} \& \mathrm{CJ}, 1843,329$.
} 
Many of the farmers themselves were quick to observe that the cattle were incapable of enduring the laborious farming chores. Sugar manufacturer William Anderson also observed that the animals were incapable of enduring laborious farm chores.

Oxen are good in their places, but for expeditious working we need something more fleet upon their feet, and more hardy, while it seems to be almost an impossibility for us to get anything else. With a few asses we might soon be able to rear for our use a superior stock of animals. ${ }^{40}$

And Benjamin J. K. Anderson, the famous Liberia explorer who visited "Mandingo Country," observed that the "horse loses vigor" upon reaching the coast. ${ }^{41}$

A 1980 study provides some clues as to why the animals "live but a short time" on the Liberian Coast. The study, entitled "Animal Traction: Guidelines for Utilization" by Michael R. Goe and Robert E. McDowell, indicated that in hot climates (that is, between 30 degrees North and 30 degrees South Latitude), draft animals experienced "more stresses than in temperate areas". ${ }^{2}$ At 4 degrees $20^{\prime}$ and 7 degrees north latitude, Liberia was well within the "warm climate region" that the authors had demarcated. The stress from the hard farm work combined with the torrid equatorial heat almost certainly caused the oxen to collapse and eventually die. The late John Ford, who published one of the first major studies on trypanosomiasis, stated that although N'Dama are adapted to the $T$. bruce $i$, yet under unfavorable circumstances, such as "stress conditions," they will succumb to the disease. ${ }^{43}$ It may have been the combination of all these unfavorable

\footnotetext{
${ }^{40}$ Ibid., 29.

${ }^{41} \mathrm{AR}, 1880,86$

${ }^{42}$ Michael R. Goe and Robert E. McDowell, "Animal Traction: Guidelines for Utilization," in Cornell International Agriculture Mimeograph (New York: Cornell University, 1980), 16.

${ }^{43}$ Ford, Trypanosomiasis, 449.
} 
circumstances that made the Liberian bovine an unsuitable candidate for agricultural labor. A similar fate may have befallen the equine population that was imported from the Cape Verde and Guinea or "Mandingo country."

While most Liberian immigrants did not link the scarcity of the horse to T. brucei, some did notice a change in the health of the animals that were brought from the interior to the coast. J.W. Lugenbeel, the Colonial Physician in Liberia, recorded in the 1840s that although horses could be found in the hinterland, they did not prosper on the Liberia coast. Lugenbeel suggested that the problem was due to the "want of proper management. ${ }^{244}$

There is no direct scientific evidence from the nineteenth century that $T$. brucei was responsible for the death and debilitation of the animals on the Liberian Coast. The closest reference to the disease was made by Lugenbeel who wrote that he saw a case of the human sleeping sickness or "lazy disease" in Liberia. ${ }^{45}$ Contemporary evidence do indicate, however that the tsetse fly, the vector of the disease, thrives in Liberia. Proof of its presence is provided by several scholars. According to a number of studies, Liberia falls in the ecological zone that breeds the tsetse flies, vectors of the trypanosome infection. The zone is demarcated by the 1,000 -millimeter isohyet or the region where the rainfall is more that forty inches. ${ }^{46}$ Liberia's western neighbor, Sierra Leone which is

\footnotetext{
${ }^{44}$ Lugenbeel, Sketches of Liberia, 30.

${ }^{45}$ Ibid., Lugenbeel, Sketches of Liberia, 38-39.

${ }^{46}$ Brooks, Landlord and Strangers, 10-13; James Webb, Desert Frontier: Ecological and Economic Change along the Western Sahel, 1600-1850 (Madison: University of Wisconsin Press, 1995), esp. chapter 4; Judith A. Carney, Black Rice: The African Origins of Rice Cultivation in the Americas (Cambridge, MA: Harvard University Press, 2001), 23-24, 46-47.
} 
also in the tsetse fly region, has a history of the animal sleeping sickness. A study conducted by D. C. Dorward and A. I. Payne in Sierra Leone concluded that the so-called "loin disease" that killed off the horses in Sierra Leone from 1856 to 1858, was very likely $T$. brucei or some other strain of the trypanosome infection. ${ }^{47}$

The lack of draft animals was a setback for agriculture. Evidence shows that the use of animal traction was not limited to sugar cane planters and manufacturers. In 1888 , it was reported that an immigrant in Brewerville used "African oxen in ploughing his land. ${ }^{48}$ Perhaps the most important evidence that the lack of draft animals adversely affected agriculture was documented by immigrant Sion Harris in 1850:

I am glad to say to you what I could never say before, that we have found out another power beyond man's power - that is, for the first man in Liberia I am working of horses plowing ... I also have two yoaks of oxen. I am halling timber out of the swamp, which has killed up hundreds of men toten it ... I have planted about 12 achers of rice. I have corn and ginger now planted. ${ }^{49}$

It is quite obvious from these comments that the scarcity of animal traction in Liberia hindered the growth of the commercial agriculture. The animals proved to be useful to both the cultivators and the sugar cane manufacturers. It can be recalled that sugar manufacturers used oxen to power their wooden sugar cane mills. In 1863, Jesse Sharp reported that he "made thirty thousand pounds of sugar, and in doing so broke down sixteen oxen, which cost me two hundred and seventy dollars." ${ }^{50}$ The cost of

${ }^{47}$ D. C. Dorward and A. I. Payne, "Deforestation, the Decline of the Horse, and the Spread of the Tsetse Fly and Trypanosomiasis," 246-256.

${ }^{48} \mathrm{AR}, 1888,48$.

${ }^{49}$ Wiley, Slaves No More, 234.

${ }^{50} \mathrm{AR}, 1863,310$. 
having to constantly purchase new stock, was certainly one of the disadvantages of commercial agriculture in nineteenth-century Liberia.

The Pattern of Immigration: Low Immigration, High Non-Agricultural Laborers

Not only was the immigration from the United States low throughout the century, but a large proportion of the population consisted of women and children. However, women did not generally perform agricultural labor. ${ }^{51}$ An examination of the major categories of the census of I843, which shows that 2,390 immigrants were alive, revealed the following: In the category 21 years of age and less than 50 years of age, 448 were women and 451 were men. Females between 16 years of age and 21 were 176, compared to 151 males in the same category. Children less than twelve years of age totaled $651 .{ }^{52}$ This means that given a potential workforce of I,226 (all categories excluding the children) in 1843, only 49 percent were capable of working in sugar and coffee production; of course, it is very possible that some of the men could be inflicted with the chills and fever in 1843. According to one source, the proportion of female immigrants continued to closely match that of the men throughout the rest of the century. ${ }^{53}$ Liberian President Daniel B. Warner thought otherwise. In 1867, he told the National Legislature

\footnotetext{
${ }^{51}$ Debra Newman discovered that the majority of the settler women worked at home or were employed as seamstress, nurses, teachers, laundresses and housekeepers. She did mention a source that reported the "wife of a merchant" cultivated a coffee farm "unassisted." Newman also made reference to Sharp's list of 1863 , which included the names of five women, who owned coffee and sugar cane farms. One of the women is Mrs. M. M. Jordan with 3 acres of sugar cane. It is not clear if Mrs. Jordan was the wife of the John Jordan, who by 1863 (the time that Sharp made the list) was probably dead. Debra L. Newman, " Laborers into the Harvest: Liberian Working Women in the Nineteenth Century," Liberia-Forum 4, 7(1988). 37.

${ }^{52}$ The Census.

${ }^{53}$ Ibid.
} 
in his Annual Message that the ratio of female to male was "considerably in excess of their male portion." 54

The importance of labor to commercial agriculture was demonstrated in the second half of the century when sugar and coffee were produced for export. Between 1850 and 1865 , the largest number of immigrants for any comparable period was resettled in Liberia. They included 5,689 from the United States and approximately 5,000 liberated Africans, making a total of $10,689 . .^{55}$ It can be recalled that the nine enterprising sugar cane farmers were part of this large migration. The liberated Africans included young boys and girls mainly between 15 and 22 years old. Many of those that were younger than fifteen years of age were assigned by the government as apprentices in the homes of Americo-Liberians. ${ }^{56}$ Others were hired, as previously noted, by the wealthier planters like Augustus Washington and William Anderson. This comment by William Anderson in 1863, demonstrates how essential the liberated Africans were to commercial agriculture.

Allow me to digress a little and speak a word for the recent laborers thrown into our midst, (the Congoes by the United States cruisers.) My entire farming operations are carried on with them and few Golahs. ... My sugar maker, cooper and fireman are Congoes, and their entire acquaintance with the material parts have been gained by observation. At wood chopping they cannot be excelled. . . .My copper is far in advance of many Americo-Liberians, who style themselves such; and likewise my sugar-maker. ${ }^{57}$

\footnotetext{
${ }^{54} \mathrm{AR}, 1868,131$.

${ }^{55}$ Annual Report, 1867, 56-64; Akpan, "The Liberian Economy," 18.

${ }^{56}$ In 1863, one "Congoe youth,"called Benjamin Coates, was a ward of Ex-President Joseph Roberts. AR, 1863, 111. For details of the apprenticeship system, see, Sawyer, The Emergence of Autocracy.

${ }^{57} \mathrm{AR}, 1863,28$.
} 
The "few Golahs" that Anderson referred to were part of the indigenous labor force that became increasingly available to the Americo-Liberians as they asserted influence over the African people through the 1800s. As noted previously, AmericoLiberian farmers hired the indigenous Africans or recruited them as apprentices. In his forthcoming book, John Yoder mentioned that the local people presented their children to Americo-Liberians as "pawns, ... a show of political loyalty ... or to provide the young person with an apprenticeship." 58 The use of humans as collateral existed in Liberia and other parts of Africa prior to the nineteenth century. ${ }^{59}$ There are references in the literature that suggest some of the immigrants did use pawns as laborers. W. W. McDonogh, a Liberian immigrant, may have alluded to the pawns in his letter of 1846 : "He [McDonogh's brother] has at this time on his farm "about 24 or 25 bound boys. . .60 William Nesbitt, ("a colored man") who spent four months in Liberia in 1853, accused the Americo-Liberians of engaging in a "species of servitude . . . that savors strongly of slavery." The "species of servitude" and "bound boys" are almost certainly allusions to the pawns.

I will conclude this chapter with a section from a comparative analysis that was done by Tom Shick to demonstrate how essential immigration was to four settler societies. Shick compared immigration in South Africa, Australia, Argentina and Liberia

\footnotetext{
${ }^{58}$ Yoder, You Kill my Ma, You Kill my Pa.

${ }^{59}$ Suzanne Miers and Igor Kopytoff, ed. Slavery in Africa: Historical and Anthropological Perspectives (Madison: University of Wisconsin Press, 1977). The chapter by Svend E. Holsoe sheds some historical light on pawning among Vai-speakers in Liberia.

${ }^{60} \mathrm{AR} \& \mathrm{CJ}, 1847,175$.

${ }^{61}$ Moses, Liberian Dreams, 87-88, 123.
} 
to make the point. Except in the case of Liberia, a large influx of colonists from the metropolis or the "mother country" enable the settlers to build sustainable economies. Shick pointed out that sheep and cattle herding developed in Australia as a result of "government-encouraged emigration." He explained that between 1820 and 1850 the British Government assisted more than "two hundred thousand" citizens to emigrate to Australia. Some of the colonists, unable to find jobs or land or both, settled farther away in the Australian outback and established frontier communities. They eventually became sheep and cattle herders. On the Liberian immigration, Shick argued that

By comparison, Liberia's settler society faltered at just the time settler societies in Australia, South Africa, and Argentina experienced significant growth and development. Liberia simply did not experience the high immigration levels that aided these other countries in the nineteenth century. The United States, itself a haven for millions of immigrants, never developed a national policy for AfroAmerican emigration to Liberia. Efforts to attract immigrants from other Africandescend populations, such as from the West Indies, proved only marginally successful. ${ }^{62}$

\section{Adaptation}

Genetic Adaptation, the Advent of Quinine and the Salubrious Interior

I will discuss three ways that enabled the immigrants to adapt in their new environment: gradual immunity to malaria, access to the drug quinine and the establishments of settlements in the elevated regions of the Liberian interior. Based on what modern medical science has learned about disease and adaptation, it is assumed that the longer the American emigrants lived in Liberia, the more they became acclimated to the new

\footnotetext{
${ }^{62}$ Shick, Behold the Promise Land, 141-142.
} 
diseases that they were not immune to ${ }^{63}$ Acclimation was enhanced by acquired immunity or some degree of tolerance to the disease. The process is long and complex. Basically, to develop resistance or tolerance for the disease, the immigrants had to live continuously in the diseased Liberian environment for a number of generations, enduring rounds of malarial attacks. Some immigrants, after the first outbreaks of fever, began to show signs of tolerance to the disease. Henry Johnson, who I quoted earlier, wrote that the African fever plagued his family for "three years ... finally, through the blessing of God, the African fever left us." ${ }^{64}$ Johnson and his family did not become malaria-free after the three years, rather they had begun to gradually adapt to the infection. Consequently, future attacks by the infection became less and less severe. The period of adaptation (three years for the Johnson family) was generally referred to as the acclimating or seasoning period.

To sustain the acquired immunity, Johnson and his family would have to continue living in the malarial environment. The next generation of Johnsons would probably begin to supplement the acquired immunity with innate resistance, which usually occurred as the blood abnormality associated with sickle cells. According to several studies, the abnormality would generally lead to the fatal sickle cell anemia. However,

\footnotetext{
${ }^{63}$ The concept of "virgin soil epidemics," which was explained in Chapter II, will help readers to understand why the immigrants (and other newcomers) died in such high numbers from diseases in West Africa. Similar tragic occurrence took place in the immediate post-Columbian era, when millions of indigenous Americans ("native Americans") were decimated by "virgin soil" disease (i.e., smallpox). The death toll was high primarily because the indigenous people were exposed to an Old World pathogen for the first time. Without any known biological resistance to the "virgin" disease, the indigenous Americans suffered heavy losses. The excessive death rate the Americans experienced was not an indication that they were biologically inferior. Similarly, the high mortality of the Liberian immigrants and other foreigners in West Africa was not a manifestation that the African environment was inherently morbid.

${ }^{64} \mathrm{AR}, 1870,329$.
} 
those who survived the deformity during childhood (i.e., they inherited the defective cell from a single parent) did not acquire the deadly sickle cell anemia. As a result, the survivors developed a form of biological resistance to malaria provided by the sickle cells. Consequently, malarial related deaths would tend to be less frequent among subsequent generations of the Johnson family, that is, those with sickle cells. ${ }^{65}$

Protection against malaria was re-enforced by the expanded use of the drug quinine in Liberia. The use of quinine as a prophylactic drug, dates back to more than four centuries when local inhabitants in Peru began to use the bark of a local tree called cinchona as a remedy for various fevers. ${ }^{66}$ By the mid-seventeenth century, the bittertasting bark-along with the news of its medicinal value-spread to Europe from the New World. In 1820, the medical properties or alkaloids were separated from the bitter cinchona bark and the resulting substance was called quinine ${ }^{67}$ Quinine would prove to be an effective cure for the fevers.

At about the same period, a number of doctors at the University of Pennsylvania in the United States reached similar conclusion about the medicinal value of quinine. ${ }^{68}$ By the 1840 s, American physicians prescribed the drug to treat the fever. ${ }^{69}$ The use of quinine spread rapidly in the United States, particularly in the South and West where the

\footnotetext{
${ }^{65}$ See, McNeill, Plague and Peoples, especially the Introduction and p. 66; Kiple, Another Dimension of the Black Diaspora, 16-21.

${ }^{66}$ Curtin, Disease and Empire, 23-28; Dale C. Smith, "Quinine and Fever: The Development of the Effective Dosage," Journal of the History of Medicine and Allied Sciences 31 (1976), 343.

${ }^{67}$ Curtin, Disease and Empire, 23.

${ }^{68}$ Ibid., 355.

${ }^{69}$ Ibid.
} 
fevers were more common. Throughout the rest of the century, quinine increasingly became the number one cure for the fever throughout the United States. ${ }^{70}$

The success of quinine in Europe and the United States in the early nineteenth century ensured that French and British soldiers in tropical West Africa and the American emigrants in Liberia would have access to the drug. In Algeria, French soldiers battling malaria received quinine as treatment against the fever as early as the $1830 \mathrm{~s}^{71}$ At the end of the 1840, British medical officers in West Africa were distributing regular doses of quinine to their soldiers. ${ }^{72}$

Quinine was probably used for the first time in Liberia during the latter half of the $1820 \mathrm{~s}^{73}$ The man who is credited with the introduction was George P. Todsen, a Danish medical doctor appointed by the ACS as physician in Liberia. ${ }^{74}$ It appears that quinine gained currency as a cure for the fever almost immediately. For instance, in 1832 the African Repository and Colonial Journal, published a communication from Liberia that contained a request for supplies. Quinine was included on the list of supplies. The communication read:

\footnotetext{
${ }^{70}$ Ibid.

${ }^{71}$ Curtin, Disease and Empire, 23-26.

${ }^{72}$ Hamet, "Malaria and Military Medicine during the Conquest of Algeria," and Erwin H. Acherknecht, "Broussais: Or a Forgotten Medical Revolution" quoted in Curtin, Death By Migration, 64.

${ }^{73}$ It is very likely that the indigenous people in Liberia had some cure for malaria prior to the introduction of the drug quinine, since they had lived with the disease all their lives. If this were the case, one can assumed that the immigrants acquired the remedy from them. The oral tradition of the indigenous people may eventually shed some light on this topic. I did find information on the subject in either the archival or secondary sources that I consulted.

${ }^{74} \mathrm{AR}, 1860,339$
} 
The list of medicines sent to you some time ago, will be a good index of what is generally wanted here ... I would strongly advise to send of French Quinine one hundred and fifty ounces. I stand at present much in need of it. ${ }^{75}$

Throughout the next decade, physicians in Liberia continued to use quinine along with a variety of generally accepted medicines and practices to fight the fever. Two common remedies were calomel to "move the bowels" and leeches attached to the skins of patients to drain excess blood. ${ }^{76}$ Of all the medicines, quinine became the most commonly used drug. The Colonial Physician, J. W. Lugenbeel, called quinine the "remidium magnum" (the best relief) for treating the African fever. ${ }^{77}$

It appears that from the 1850 to the end of the century onward, quinine was generally prescribed as prophylaxis. One indication of this use is found in a letter that John Seys wrote in 1857. Seys had received a new group of immigrants and was responsible for resettling them in one of the settlements that were founded in the interior. He informed the ACS that prior to departure for the settlement, that each of the newcomers was given a "dose of quinine." regime was maintained.

In the absence of statistical evidence, the true impact that the drug quinine had on malaria in Liberia is hard to determine. However, given the documented proof of the

\footnotetext{
${ }^{15} \mathrm{AR} \& \mathrm{C} \mathrm{J}, 1832,44-45$.

${ }^{76}$ Lugenbeel, Sketches of Liberia, 32-34.

${ }^{77}$ Ibid. 34.

${ }^{78}$ AR, $1857,139$.
} 
success of quinine in French and British West Africa, it is reasonable to surmise that the drug did mitigate the deadly impact of malaria in Liberia. ${ }^{79}$

The final measure, establishment of settlements inland from the coast, had the potential to also reduce mortality. This policy was consistent with conventional wisdom of the time which emphasized that elevated lands were relatively freer of malaria than the low, marshy coast lands. It was generally believed that malaria, meaning "bad air" in Italian, developed in moist, stagnant waters. Therefore, by living on high lands, away from the foul air, one could avoid the disease ${ }^{80}$ The height of the elevation hill varied, usually depending on the geography of the region. By the nineteenth century, British colonial officials decided — based on the available medical knowledge — that the homes and administrative offices in the tropics should be constructed on hills that were anywhere from 2,500 to 4,000 feet above sea level. ${ }^{81}$

Evidence that the Hill Stations guaranteed safety from malaria is mixed. Philip Curtin discovered that in some parts of the tropics, hill stations became refuges from malaria (e.g., Jamaica, 2,500 to 4,000 feet), while others (e.g., Algeria, 2,000 to 3,000 feet) did not have that advantage. ${ }^{82}$ At the Jamaican Hill Station, for example, the mortality rate among European soldiers dropped significantly from 1837 to 1846 , “a

\footnotetext{
${ }^{79}$ Curtin, Disease and Empire.

${ }^{80}$ Stephen Frenkel and John Western, "Pretext or Prophylaxis? Racial Segregation and Malaria Mosquitoes in a British Tropical Colony: Sierra Leone," Annals of the Association of American Geographers 78, 2 (1988), 213.

${ }^{81}$ Philip Curtin, Death by Migration: Europe's Encounter with the Tropical World in the Nineteenth Century (New York: Cambridge University Press, 1995), 47-50.

${ }^{82}$ Philip Curtin, Death by Migration, 47-50.
} 
change credited to the move." ${ }^{83}$ In spite of the apparent uncertainty about the effectiveness of hill stations, the underlying logic behind the concept made perfect scientific sense: The farther away from stagnant waters, the breeding ground for the Anopheles mosquitoes, the less likely one was to be bitten by the four-legged creature. The problem was to determine just how far the mosquito could traverse. By the early twentieth century, British medical officers in Sierra Leone assumed that a distance of "a quarter of a mile" was a safe distance from the low, marshy breeding grounds of the mosquitoes. ${ }^{84}$

It was due partly to such thinking and the prevailing notion that the African interior was healthier than the coast that motivated the ACS to encourage the settlers to establish settlements in the interior. Several travelers from the Liberian coast who visited the interior, including Edward Blyden, George Seymour (a black American missionary) and Rev. John Seys, spoke eloquently about the healthier interior. ${ }^{85}$ The three men were eager supporters of interior settlement because they believed that the hinterland was more salubrious than the marshy coast. Seymour spent most of his approximately two decades in Liberia preaching to Bassa and Kpelle people in the interior. Seys served in several positions in Liberia for the ACS and the United States Government. As Special Agent of the ACS in Liberia, Seys was instrumental in the founding of interior settlements. One of the settlements he helped to organize in 1857 was Careysburg.

\footnotetext{
${ }^{83}$ Ibid. 49.

${ }^{84}$ Frenkel and Western, "Pretext or Prophylaxis," 216.

${ }^{85}$ AR, 1877, 90-93; Ibid., 1857. 138-139; Ibid., 1858, 4-19; Annual Report, 1857, 5-7.
} 
The second epigraph at the beginning of this chapter, which states, "while those in the interior have had no fever," was in reference to new immigrants in Careysburg. ${ }^{86}$ There are other accounts about the salubrity of Careysburg. In 1858, James Skipwith of Monrovia wrote that "The People at Careysburg do not suffer as the People that Stop about Monrovia \& on the Sea Board. ${ }^{87}$ About two years later, Skipwith reiterated that Careysburg was "a healthy place."

Another interior settlement that Seys was instrumental in establishing, was Robertsport, the capital of Cape Mount County. Robertsport was situated about forty miles north of Monrovia. The settlement was reported to have "sufficient elevation to secure, under ordinary circumstances, general good health. ${ }^{89}$ Blyden also had firsthand knowledge about the health of the Liberian interior since he was directly involved in the formation of the Arthington settlement. The settlement was located in the lush forest of the Boporo Country. Blyden described the region:

The whole Boporo region is elevated enough to give that coolness at night and in the morning which invigorates the native and makes life agreeable and healthful to the foreigner. The view for miles around is picturesque, embracing lofty hills on the east and north, and beautiful plains on the west and south. ${ }^{90}$

By the end of the century, the Liberian government had planted additional settlements in the interior settlements. While the policy was motivated primarily by economic and political considerations, there were those who staunchly supported the idea

\footnotetext{
${ }^{86} \mathrm{AR}, 1857,169$

${ }^{87}$ Wiley, Slaves No More, 90.

${ }^{88}$ 1bid., 96 .

${ }^{89}$ Annual Report, $1857,13$.

${ }^{90} \mathrm{AR}, 1877,90$.
} 
because they believed it was healthier than the mosquito-infested coast. In 1880 , for example, former President Daniel Warner made the following remarks:

The mortality among the early emigrants, which often cast a gloom over the Colonization enterprize and had the effect to deter many from coming to Liberia, is no longer experienced. Of the seventy-five landed here since the $6^{\text {th }}$ of January last, only two have died from all causes. As the Country is opened up and new comers push forward to the interior, its insalubrity diminishes. ${ }^{91}$

Warner had been an eyewitness to the malaria epidemic of the early period. He emigrated in 1823 , barely two years after the colony was established. From the tender age of eight, the would-be president lived to see the African fever killed scores of immigrants. Now at the ripe age of sixty-five, Warner was one of few immigrants who crossed the Atlantic Ocean without reaching the Celestial World (to paraphrase historian Moses Jeremiah) within the first year or decades, for that matter.

${ }^{\text {Tा ACS, } 1880,7 .}$ 


\section{CHAPTER VI}

\section{THE COLLAPSE AND DECLINE OF SUGAR AND COFFEE}

People in America say Liberians are lazy. It is not so. They labor under many disadvantage getting the lowest prices for [their] labor; paying the highest prices for goods."

-Coffee Planter, Alonzo Hoggard

\section{International Forces: Declining Prices}

Coffee planter Alonzo Hoggard made the remarks about "many disadvantages" in 1880 when the price of coffee was about 25 cents a pound. ${ }^{2}$ The 1880 price was a treasure compared to what the planters received for their crops in the 1890s. By 1898 the price of a pound of coffee had dropped to 6 cents. ${ }^{3}$ Alonzo Hoggard and the other coffee planters faced another major disadvantage. The second problem, according the Svend E.

Holsoe and co-author Bernard L. Herman, was

finding sufficient labor to pick and process the crops. Although there were indigenous Africans in the neighborhood, they were not interested in doing that kind of work ... the wages were insufficient for the amount of work involved. ${ }^{4}$

With declining prices and labor scarcity, many of the planters could not maintain their coffee farms. By 1902, a local newspaper wrote: "The fine farms that once flourished on

\footnotetext{
Svend E. Holsoe and Bernand L. Max,, A Land and Life Remembered: Americo-Liberian Folk Architecture (Athens, GA.: University of Georgia Press, 1988), 10.

${ }^{2}$ Ibid.

${ }^{3}$ Ibid.

${ }^{4}$ Ibid.
} 
the Saint Paul's River" are "all going down for the want of labourers." The sugar industry had collapsed because of similar circumstances. By 1880, the price of a pound of sugar was 6 cents, having fallen precipitously since the 1840s when it sold for 13 and I 2 cents a pound. ${ }^{6}$

Declining prices also led to the collapse of Liberia's other export commodities (e.g., palm oil, camwood and palm kernels). Palm oil and camwood accounted for the lion share of Liberia's foreign revenue. ${ }^{7}$ Palm kernels became part of the transatlantic commerce reportedly when a Liberian named Samuel Herring, introduced the palm kernel trade to the world between 1848 and $1849 . "{ }^{\prime 8}$ After 1870, the prices of all three commodities began to drop as a result of falling demand in Europe and the United States. By 1900 , prices for these commodities were so low that most of the once prosperous “merchant princes" were forced out of business. ${ }^{9}$

Aside from falling prices and the scarcity of labor, there are other reasons for the collapse of Liberia's overseas commerce in the last quarter of the nineteenth century. They include poor banking system, inadequate technology and foreign competition and the death of prominent merchants, ${ }^{10}$ I will focus on two of causes: Inadequate technology

\footnotetext{
5The Liberian Recorder, quoted in Akpan, "The Liberian Economy," 23.

${ }^{6}$ Mintz, Sweetness and Power, 144; Liberia Herald, 1842; Ibid., 1847; Annual Report, 1880, 15.

${ }^{7}$ Syfert, "The Liberian Coasting Trade," 217-235; Webster and Boahen, History of West Africa, 150-152.

${ }^{8}$ Richardson, Liberia's Past and Present, 250.

${ }^{9}$ Webster and Boahen, History' of West Africa, 150-152. Sawyer, The Emergence of Autocracy in Liberia, 124-164; Akpan, "The Liberian Economy," 22-24.

${ }^{10}$ Ibid.
} 
and foreign competition. In my view, both played decisive roles in the decline of sugar and coffee. The other causes have been discussed quite extensively in several texts. ${ }^{11}$

\section{Foreign Competition}

Overproduction was one form of foreign competition that eventually proved destructive to sugar and coffee-along with palm oil, camwood and palm kernels. It took the form of increased production of goods which were viewed as cheaper substitutes or superior qualities. Sugar and coffee fall more closely under the "superior qualities" explanation, while palm oil, camwood and palm kernels can be linked to the "cheaper substitutes" model.

It was the invention of cheaper substitutes that doomed Liberia's wealthy merchants and their counterparts in West Africa. Their main exports of vegetable oils were gradually replaced with new inventions in the last quarter of te 1800s. From the 1870s onward, scientific innovations eliminated the need for palm oil, camwood and palm kernels in Europe and the United States. The discovery of petroleum in Pennsylvania in 1859 gradually wiped out the need for lubricants derived from palm oil. ${ }^{12}$ Kerosene, developed from petroleum, dealt another blow to palm oil; palm oil was one of the materials used to make candles. ${ }^{13}$ The discovery of cheaper sources of soap and

\footnotetext{
"Sawyer, The Emergence of Autocracy in Liberia, 124-164; Akpan, "The Liberian Economy," 22-24.

${ }^{12}$ Lynn, Commerce and Economic Change in West Africa, 116-122.

${ }^{13}$ Ibid.
} 
cooking oil, made groundnuts and palm kernel oil uneconomical. ${ }^{14}$ Finally, Liberian merchants lost the camwood trade when aniline dye was invented. ${ }^{15}$

Arrowroot and ginger were two minor agricultural exports that also declined in the last quarter of the century due to slumping prices. Records showed that ginger and arrowroot were exported in $1852 .{ }^{16}$ However, until the 1860 s both crops were cultivated mainly in family gardens for domestic consumption. After 1865, larger quantities of ginger and arrowroot were grown by the Barbadian immigrants. The Barbadian settlement called Crozerville, located about 20 miles from Monrovia near the St. Paul River, was noted for the cultivation of ginger and arrowroot. For instance, it was reported in 1868 that "the Barbados Agricultural Society, shipped 3,500 pounds of ginger, 4,300 pounds arrowroot" overseas. ${ }^{17}$ Some ginger and arrowroot were also exported in $1871 .{ }^{18}$ Both crops began to decline from 1890 because of falling prices. ${ }^{19}$ By the end of the decade, neither ginger nor arrowroot was cultivated for export.

For Liberian planters, it was their inability to upgrade the quality of sugar and coffee to new international standards that contributed to the fall in prices. After the 1870 s, sugar and coffee production, which had fallen in the 1850 s and 1860 s, rapidly increased. For example, by 1880 sugar manufacturers in the United States (after initial

\footnotetext{
${ }^{14}$ Ibid.

${ }^{15}$ Syfert, "The Liberian Coasting Trade," 226-227.

${ }^{16} \mathrm{AR}, 1852,242$.

${ }^{17} \mathrm{AR}, 1868,307$.

${ }^{18}$ Ibid., 1871,318

${ }^{19}$ Ibid. 1890, 29-30
} 
disappointments with "Chinese thieves and African vagabonds") finally restored the sugar industry that had been destroyed by the civil war. ${ }^{20}$ With the restoration, sugar output steadily rose in the United States. In addition, by the 1890 s, Cuba exported nearly all of its sugar to the United States. ${ }^{21}$ The increased production of sugar in the United States and Cuba was a disaster for the small sugar manufacturers in Liberia, since they had sold the bulk of their sugar export in the United States. Unable to raise the standard of their sugar to the level of the producers in the Americas, the Liberian manufacturers were eventually squeezed out of the market.

For the decline of coffee, it should be pointed out that the fascination with $C$. liberica in the 1870 s and early 1880 s was due partly to the expectation that the Liberian species was resistant to the deadly coffee disease, hemileia vastatrix or "rust." It later turned out, however, that $C$. liberica was also susceptible to the rust." ${ }^{22}$ In Chapter IV, it was indicated that worldwide coffee output declined after Brazil, the largest coffee producer, abolished the slave trade in 1850 . For sometime afterward, Brazilian coffee planters were plagued by acute labor shortage. By 1876 , Brazil regained its status as a leading coffee exporter. In that year Brazilian planters sold three-fourths of the "340 million pounds of coffee" that the United States imported. ${ }^{23}$ With such large quantity of coffee from Brazil, it was imperative that Liberian farmers improve that standard of their product to stay competitive. This is when the availability of technology was essential.

\footnotetext{
${ }^{20}$ Sitterson, Sugar Cane Country, 238-250.

${ }^{21}$ Mary Beth Norton et al., A People and a Nation: A History of the United States (Boston, MA.: Houghton Mifflin Co., 1989), 419.

${ }^{22}$ Pendergrast, Uncommon Grounds, 44.

${ }^{23}$ Ibid., 62.
} 
The farmers did not have the capital to invest in the advanced technology that was available for improving the quality of their sugar and coffee.

Inadequate Technology

Compared to the Liberian merchants and their contemporaries in other parts of West Africa who lost their trade because of synthetic substitutes, Liberian sugar manufacturers and coffee planters had a better chance to reverse their fortune. To reverse the situation, the Liberians needed capital to expand production and upgrade the quality of their sugar cane and coffee so that they could compete with their counterparts from the Americas.

Declining prices for sugar and coffee was the immediate reason why farmers withdrew from sugar cane and coffee farming. In both cases, it seems that farmers could have continued to operate profitably if they had lowered the cost of production. Farmers can cut costs by increasing production and improving efficiency. Sugar cane farmers in Louisiana and the Caribbean continued to operate when prices fell because they expanded the volume of production, improved transportation and adopted new scientific methods to upgrade the quality and lower the cost of their sugar. Coffee farmers in Latin America employed new technology for preparing coffee, which allowed them to export superior tasting coffee beans. Liberian coffee beans were "inferior" primarily because they were poorly prepared, not because $C$. liberica was a flawed species. Essentially, it was the inability of Liberian farmers to adapt to changing global circumstances that led to collapse of the sugar trade and the decline of coffee. And they could not adjust to the changes because the price they received from their crops was barely sufficient to cover 
their operational cost. As Alonzo Hoggard pointed out in the epigraph, the farmers "labor under many disadvantages getting the lowest prices" for their produce.

In the sugar industry, the change in technology which enabled planters in the New World to continue to operate profitably in spite of falling prices, became obvious from the 1860s. Most manufacturers in the Americas began to replace the conventional animal-, wind- and water-powered sugar cane mills with the more efficient and labor-saving steam sugar cane mills. One of the main advantages of the steam sugar cane mill, was the speed with which it chewed up the cane stalks to extract the juice. The output of the steam sugar mill was reported to have been "nine times greater than" all the other types of mills. ${ }^{24}$

The difference that the steam sugar cane mill made in the industry could be compared to the difference that Henry Ford's assembly line brought to the automotive industry in the twentieth century. Both the steam sugar cane mill and the assembly line increased output while reducing the cost of labor. By the 1860s, all the major sugar producers in the New World had adopted the steam mill. Of the 1,422 "ingenios" or sugar cane mills in Cuba in 1846, 20 percent were steam-operated. When the total number of mills dropped in 1861 , more than half of those that remained were steamoperated. ${ }^{25}$ In the United States the transition to steam mills began from about the $1820 \mathrm{~s}$ and continued throughout the rest of the century. ${ }^{26}$

In the meantime, while planters in the Americas were adopting steam mills, the majority of the farmers in Liberia had access to neither the cumbersome wooden mill nor

\footnotetext{
${ }^{24}$ Klein, African Slavery, 98.

${ }^{25}$ Ibid.

${ }^{26}$ Sitterson, Sugar Cane Country, 51, 224-250.
} 
the steam mill. In 1863 , only two of the ten mills in the country were powered by steam engine. Of the approximately seventeen mills purchased in the entire sugar cane era, less than half were steam sugar cane mills. It was inevitable that the widening technological gap between the Liberian sugar industry and the rest of the sugar-producing world would force the former out of the sugar market. The United States Civil War probably gave Liberian sugar manufacturers a respite from inevitable doom in the $1860 \mathrm{~s}$. After the war, it became increasingly difficult for Liberians to sell their sugar in the United States. The following report published in the African Repository of 1868 illustrates this point.

He [Augustus Washington] has sold twenty-five thousand pounds of sugar, in the New York market alone, during the past year. The duties are so high that Liberian products do not find ready or profitable sale in this country. [United States] ${ }^{27}$

Besides the steam mills, planters in the Americas, adopted new technologies such as the increased use of the plow rather than the hoe, the adoption of new and improved seeds, and the fertilization. ${ }^{28}$ All these measures had the capacity to improve the quality of the product and reduce the cost of operation. For their part, the Liberian sugar manufacturer remained attached to the hoe, since the plow could not be transplanted because of the trypanosomiasis and the farmers were incapable of acquiring the new seeds and fertilizers because they did not have the capital.

Inadequate transportation in Liberia also contributed to the high cost of manufacturing sugar. Farmers generally transported the harvested cane to the mills by canoes. Sugar cane planter William Anderson's comment of 1862 that "the expense of

\footnotetext{
${ }^{27} \mathrm{AR}, 1868,376$.

${ }^{28}$ Sitterson, Sugar Cane Country, 277-278.
} 
transporting cane by water is great" ${ }^{\prime 29}$ confirms the high cost of transportation.

Transportation was not improved and by the 1870s, as the price of sugar dropped precipitously, the profits of Anderson and the other farmers became even smaller. In the United States and the Caribbean, farmers benefitted from improved systems of transportation, which cut their costs and kept them in business. For example, the development of a railroad in the countryside of Cuba led to the expansion of sugar cane farming. ${ }^{30}$

Without the resources to expand production, improve cultivation and output, and develop better system of transportation, measures that would have cut cost, the Liberian sugar industry was very vulnerable to declining prices. On the other hand, sugar cane farmers in United States and the Caribbean adopted new techniques to reduce their expenditures and as a result, continued to operate in spite of falling prices. Therefore, the underlying cause for the collapse of Liberian sugar industry was the lack of capital. The scarcity of labor and the institutional defects such as inadequate banking system, could have been overcome with capital. Although labor was scarce, workers could still be found for hire-at higher wages. For instance, it was the farmers' unwillingness or inability, according to one source, to equitably compensate workers that resulted in the shortage of labor. ${ }^{31}$

Coffee farmers encountered most of the difficulties that sugar cane farmers faced. The greatest problem for coffee farmers by the last two decades of the century was their

${ }^{29}$ Liberia Herald, (n.d.), 1863, quoted in AR, 1863, 28.

\footnotetext{
${ }^{30}$ Klein, African Slavery, 98.

${ }^{31}$ Akpan, "The Liberian Economy," 23.
} 
inability to produce coffee beans that could match or surpass those from Latin America in taste and preference. It can be recalled that in the 1870 s, the Liberian coffee received several international recognitions for its superior quality (e.g., two awards at the Centennial Exhibition in Philadelphia in 1876). Therefore, the decline in the demand for the Liberian coffee was not the result of any inherent defect of $C$. liberica. The problem was the lack of the appropriate technology to prepare the coffee according to international standards.

Many different factors combined to make what consumers considered the perfect cup of coffee. Those factors include the species of coffee, how it is cultivated and finally how it is prepared for consumption. From the evidence, it seems that the procedure Liberian farmers used to prepare the coffee berries, such as for cleaning and storage, contributed to its inferior quality. Coffee farmers used a procedure called the "dry method" in preparing the coffee berries for cleaning. The procedure involved placing the harvested coffee berries on the ground in the sun so that the outer coverings were dried and shriveled, thus making hulling easier and faster. The "dry method" could last for several weeks, after which time the dried, shriveled husks could be removed either manually (with a mortar and pestle) or mechanically (in a hulling machine). Most farmers, including Liberians, chose the "dry method" because it was simple and inexpensive.

However, studies showed that the "dry method" was a major source of the bad or "off" flavors that consumers dislike. One source identified two ways in which the "dry method" could affect the taste of coffee. First, because of prolonged contact with the 
ground, the coffee berries tended to "develop mold or absorb other unpleasant earthly tastes ... known as the Rioy flavor." 32 Although some customers reportedly adjusted to the Rioy flavor, many more disliked the "strong, iodinelike, malodorous, rank" taste. Second, the coffee beans could acquire "unpleasant or off tastes" if the berries "ferment inside the skin," during the "dry method." The fermentation usually comes about when the berries are placed too close together while being dried. ${ }^{33}$

Many farmers in Latin America adopted an alternative procedure called the "wet method," which produced a higher quality of coffee beans. But the wet method was far more expensive than the dry method. Liberian farmers (along with a large number of small farmers in Latin America) did not have the capital to purchase the more expensive "special equipment" required in the "wet method." The larger planters in Latin America, including the Columbians, adopted the more expensive wet method. This would explain consumers' preference for the Columbian coffee over the Liberian brand. While Liberian farmers continued to export second-rate coffee beans, their wealthier counterparts with the expensive "special equipment" were offering consumers beans of "superior" quality. ${ }^{34}$ The choice for coffee drinkers was quite obvious.

Another deficiency that contributed to the poor taste of the Liberian coffee was improper storage facility. To maintain the quality of the coffee, farmers must ensure that the beans remain dry and free of moisture during storage and transportation. ${ }^{35}$ This

\footnotetext{
${ }^{32}$ Pendergrast, Uncommon Grounds, 26-27.

${ }^{33}$ Ibid.

${ }^{34}$ V. D. Wickizer, The World Coffee Economy: With Special Reference to Control Schemes (California: Stanford University, 1943), 42.

${ }^{35}$ Ibid., 44.
} 
requirement was certainly a challenge for the Liberian farmer who lived in the year-round moist tropical environment. In 1874, The New Era Newspaper reported that although farmers harvested and cleaned the coffee during the "wet and moist season" only a very small number of them knew how to preserve the dryness of the beans during the rainy months. ${ }^{36}$

As more evidence becomes available, it is likely that researchers will find that farmers had difficulty keeping the coffee beans dry. It would not have been unusual for coffee beans to remain in the wet, moist condition during the rainy months due to the scarcity of labor to haul the commodity to the coast to be shipped overseas. Moreover, the farming communities along the rivers (St.Paul and St. John) used canoes to transport their coffee to Monrovia and Buchanan for sale or shipment overseas. During the wet months the topless canoes provided no protection from the heavy rain.

With improved method of storage and transportation, the Liberian coffee might have retained the "superior" quality it became famous for in the 1870 s. New scientific methods enabled the wealthier producers in the Americas to produce coffee beans that consumers considered superior to the Liberian product. That consumers began to reject the Liberian coffee by the 1890s is not a surprise. This was the beginning of the era of competition and product differentiation. With a greater number of coffee producers, consumers had a wider variety of choices, something they did not have in the 1860 s and 1870s.

${ }^{36}$ The New Era, 24 Sept., quoted in AR, 1874, 368-369. 
Liberia's export trade in coffee collapsed because the farmers were incapable of improving the quality of their commodity at a time when competitors adopted new standards and technology for upgrading coffee. In retrospect, it appears that the coffee hulling machine, which had such a huge positive impact on the spread of coffee, contributed to the poor quality of the Liberian coffee. One early twentieth-century source indicates that the huller was inefficient because it destroyed the berries by breaking them up. As a result, the coffee arrived overseas in "broken and imperfect condition." new and improved coffee machine would have eliminated the problem.

In conclusion, a combination of factors led to the decline of Liberia's overseas trade in sugar and coffee during the last quarter of the nineteenth century. The factors ranged from operational deficiency such as labor shortage and the lack of appropriate technology, to institutional defects like inadequate banking system. All of these limitations could have been resolved had the farmers or the national government or the ACS had the resources to do so. In the final analysis, the underlying cause for the collapse of the overseas trade in sugar and coffee was the lack of capital. Alonzo Hoggard's comment-in the epigraph that opens this chapter-that he and the other planters "labor under many disadvantages" was a reference to various obstacles, such as inadequate technology, they encountered.

\footnotetext{
${ }^{37}$ Johnston, Liberia, vol. 1, 402; James Sibley, Liberia Old and New: A Study of its Social and Economic Background with Possibilities for Development (Garden City, New York: N. P., 1928), 109-110.
} 


\section{CHAPTER VII \\ CONCLUSION: RETHINKING THE NOTION OF "NEGLECT"}

Men resembled their times more than they do their fathers.

- Marc Bloch ${ }^{1}$

\section{The Critique}

At the beginning of this dissertation, I questioned the validity of the current interpretation on commercial agriculture in nineteenth-century Liberia. In the interpretation, scholars claimed that the free "Negroes," who were repatriated to Liberia by the American Colonization Society, failed to cultivate staple crops for export because of their disdain for agricultural labor. As a corollary, the scholars claimed that the immigrants were lazy. The allegation that the Liberian immigrants disliked agricultural labor is based on the following arguments: First, that the ex-slaves misconstrued their freedom in Liberia for abstinence from work; Second, that since the majority were former slaves, agriculture evoked the distasteful memories of slavery; Finally, the immigrants shunned the African food and instead chose the American diet which was incompatible with the desire to become farmers.

The allegation that the ex-slaves refused to work because they interpreted their freedom for abstinence from work, rests on a partial explanation that one governor advanced for the failure of agriculture. Monday Akpan, who presented the "evidence," omitted the two other reasons that the governor gave: that the immigrants were unfamiliar

'Marc Bloch, The Historian's Craft, trans. Peter Putnam, (New York: Vintage Books, 1953), 35. 
with the method of farming in Liberia and that most of them preferred trade to commerce. Additionally, Akpan ignored the varied reasons that other administrators proposed for the failure of agriculture (e.g., the lack of animal traction and capital).

Besides the selective presentation of the evidence, there are sufficient facts in the archives to refute the notion that the immigrants interpreted their freedom in Liberia for abstinence from work. For example, the archival sources and the personal correspondence of the immigrants revealed that many of the immigrants attempted to cultivate the land that was allocated to them. Some of them did succeed in producing sugar and coffee after 1850 . Those who chose commerce over agriculture, quite often, did so because of the comparative advantage of the former. Farming in Liberia was different from what the immigrants were familiar with. One notable difference was the scarcity of draft animals. A single individual or family could not establish the large-scale plantations that the ACS expected the immigrants to operate without outside labor. However, labor was scarce, and as a result, expensive.

The second charge that the immigrants shunned agriculture because it brought back the distasteful memories of American slavery, is unsupported by any evidence. Its author, the late Gus Liebenow, mentioned it as a matter of fact. I was able to demonstrate, from the letters of former slaves, that they were happy to finally obtain their "forty acres" in Liberia.

The notion that the immigrants preferred American food over the African diet, the third argument, turned out to be a faulty generalization. As evidence, Akpan cited the names of two or three persons that complained of the monotony of the African diet after 
they returned to the United States. But Akpan overlooked the facts, which indicated the majority who remained in Liberia, learned to cherish the African cuisine. In fact, the vast majority was too poor to live on imported food. They cultivated gardens with cassava and other African crops. Some used the African foods to prepare substitutes of their favorite American diet. Even for those who received occasional supplies of foods from former masters, the African diet remained the staple food. The evidence showed that it was the elite, mostly merchants and politicians who ate the imported flour and bacon. 1 presented anecdotal evidence that plainly demonstrated some of the upper class immigrants did enjoy Liberian dishes. Two stories in the archives illustrated that the elites savored Liberian cuisine. The narratives showed that in 1859 and 1871 some prominent members of the upper class such as former President Joseph J. Roberts and future President Garrison Gibson, appreciated the very popular Liberian dish called dorbouy or dumboy.

I still questioned what I believe is the warp argument that preference for American food was tantamount to the contempt for agriculture. The example of British settlers in the West Indies, who shunned the native diet and imported foods from other European nations, was advanced to prove that their preference did not prevent them from becoming wealthy planters. Finally, I used a study by Sidney Mintz and a quotation by the black American, Booker T. Washington, to demonstrate that the desire for specific foods by those who had been deprived of it for so long, was a way to satisfy their suppressed desires and cravings. Such anxieties, in the case of former slaves in Liberian immigrants, may have had absolutely nothing to do with their dislike or approval for agriculture. 
As to the inference that the settlers were lazy, I believe that scholars were probably led to that conclusion by references and hints in the archives. There is no evidence or illustration in the historiography of the indolence, except the allegation that the settlers failed to develop a sustainable agrarian economy based on the cultivation of staple crops. I traced the charge of laziness in the archives to the era of slavery. A number of scholars noted that the allegation of the slothful "Negro," tended to be increasingly linked to slaves and former slaves in the New World and as well as in Africa.

In the United States, the embodiment of the lazy African slave was "Sambo," stereotyped as inherently childlike in attitude and without the will to succeed in life. During the flood-tide of the abolition movement in the nineteenth century, slave owners portrayed former slaves as slothful and criminally minded. One of the goals of the ACS was to remove these so-called lazy, "free Negroes" from the United States.

Proof that the charge of indolence was applied indiscriminately to former slaves everywhere is illustrated in the study of Frederick Cooper, among others. Cooper discovered that in the West Indies and Africa, former slaves were invariably labeled as lazy. His conclusion, supported by several others including Thomas Holt, is that the allegation of laziness stemmed from the resistance by the former slaves to attempts by their erstwhile owners to choose where they worked and what kind of jobs they performed.

The conflict over how the immigrants in Liberia allocated their time was probably the source of the allegation of laziness that is found scattered in the archives. Even though the ACS encouraged the settlers to engaged in commerce, it was convinced that 
agriculture was more reliable. Therefore, it urged the settlers to grow staple crops.

However, the settlers realized that farming in Liberia was very strenuous, and moreover, returns were precarious. Consequently, many of them chose commerce which they believed guaranteed for them a stable source of income. Thus, the settlers were accused of neglecting agriculture and swarming to commerce.

\section{The Alternative Interpretation}

The immigrants encountered two major setbacks in their efforts to grow staple crops for export. One drawback to agriculture, especially between 1822 and 1843 , was the shortage of labor in the immigrant population; the other was the lack of capital. There were two main reasons for the scarcity of labor. The first was mortality resulting from diseases. Malaria decimated the immigrant population and normally left survivors too enfeebled to perform daily chores. Low immigration was the other source of the labor shortage. The roughly even gender ratio among the immigrants further accentuated the problem because settler women did not usually perform farm work.

The second disadvantage, the lack of capital, prevented the largely impoverished settlers from participating in commercial agriculture. Sugar and coffee production required considerable investment in capital and equipment. This requirement was beyond the means of the majority of the settlers, most of whom were former slaves. With labor and capital severely limited, commercial agriculture had hardly any chance of succeeding in Liberia. But it did succeed-although for a brief period.

The production of sugar and coffee for export began in the second half of the century. A number of factors contributed to the success. Those factors were the 
availability of capital, increased immigration, the demand for sugar and coffee on the international market and the adaptation of the immigrants to their new environment. I traced the success of commercial agriculture to developments in the first half of the century. For instance, some of the early policies of the government, such as the establishment of agricultural experimental stations, called public farms, provided the settlers with the knowledge and experience that was needed to succeed.

I discovered that a small proportion of the settlers, who were educated and emigrated with some capital or had access to resources in Liberia, invested in commercial agriculture. Many of them were of the artisan and entrepreneurial classes. The vast majority of the immigrants were uneducated and either unskilled or semiskilled. It appears that the lack of education and skills weighed heavily against this group.

The collapse of the sugar industry by the 1880 s and the decline of coffee in the last decade of the century, was directly tied to changing trends in the global economy. Liberian farmers did not have the capital to acquire the technology and scientific innovations to match the standards of sugar and coffee produced in the Americas. For the farmers, the competition could not have come at a worse time. The worldwide depression of the 1870 s to $1880 \mathrm{~s}$, which led to lowered demand for goods and services around the world, exacerbated the problem for the farmers. With falling revenue and labor scarcity, the farmers could not maintain the coffee and sugar operations.

The history of commercial agriculture of nineteenth-century Liberia is seemingly unimpressive, considering for instance, that the total annual export of sugar and coffee paled consistently in comparison to the huge quantities sold by the leading producers in 
the Americas. One must realize that until at least the 1850 s most of the large coffee and sugar producers in the New World (e.g., the United States) relied on slave labor. The importance of labor in the production of these staples becomes even more relevant, when it is recalled that the attempts by the French and British to cultivate some of these very crops in West Africa in the 1800s were unsuccessful. One of the causes for the failures, as noted in Chapter I, was the shortage of labor. The French and British later turned to trade in African products, collected and processed primarily by Africans.

This pattern of trade, not the cultivation of staple crops for export, became the major economic activity for the British and French on the West Coast of Africa throughout a large part of the century. Historian Christopher Fyfe's quip (mentioned in Chapter I) that when the African immigrants in Sierra Leone chose trade over cultivation they were simply emulating Europeans, may very well apply to the many AmericoLiberians who preferred trade to commerce.

Another way of interpreting the situation is to consider that those AmericoLiberians who became merchants, did not want to follow in the footsteps of their former masters in the United States who kept urging them to also become planters. Instead, they chose the most popular career option of their time. The option was trade. In doing so, the Americo-Liberians were following the wisdom of the Arabic proverb that March Bloch, the famous French geographer and historian, quoted: "Men resemble their times more than they do their fathers." 


\section{BIBLIOGRAPHY}

Primary Sources

Archival Collections

African Repository and Colonial Journal.

African Repository.

Annual Report of the American Colonization Society.

U. S., Congress, Senate, U. S. Navy Dept., Tables Showing the Number of Emigrants and Recaptured Africans Sent to the Colony of Liberia by the Govt. of the U. S., Together With A Census of the Colony, and a Report of its Commerce, Sept., 1843: Senate Document No. $150,28^{\text {th }}$ Cong., $2^{\text {nd }}$. Session, 1845.

Newspapers

Liberia Herald (1800s)

St. Cloud Tribune-Florida (1906)

Books, Pamphlets, Articles and Edited Collections of Documents

Ashmun, Jehudi. The Liberian Farmer; Or, Colonist's Guide to Independence and Domestic Comfort. Philadelphia: Kaswell and Barrington, 1835.

. "On Mixed Races in Liberia." Annual Report of The Board of Regents of the Smithsonian Institution. Washington: Government Printing Office, 1871.

Blyden, Edward W. “A Chapter in Liberian History.” Freetown, Sierra Leone: 1892.

Brooks, George E. “A. A. Adee's Journal of a Visit to Liberia in 1827." Liberian Studies Journal, 1, 1 (1968): 56-56-72.

Brown, George S. Brown's Abridged Journal, Containing a Brief Account of the Life, Trials and Travels of Geo. S. Brown, Six years a Missionary in Liberia, West Africa: A Miracle of God's Grace. New York. Prescott and Wilson, 1849.

Brown, Robert T. "Immigrants To Liberia 1843 to 1865: An Alphabetical Listing." Liberian Studies Research Working Paper No. 7. Philadelphia: Institute for Liberian Studies, 1980.

Buxton, Thomas F. The African Slave Trade and Its Remedy. London: Dawsons of Pall Mall, 1840. 
Crofts, Daniel., ed. Cobb's Ordeal: The Diaries of a Virginia Farmer, 1842-1872. Athens:University of Georgia, 1997.

Gurley, Ralph Randolph. Life of Jehudi Ashmun, late Colonial Agent in Liberia. With an Appendix, containing Extracts from His Journal and Other Writings; With a Brief Sketch of the Live of the Rev. Lott Cary. New York: Robinson \& Franklin. 1839.

Jefferson, Thomas. Notes on the State of Virginia. ed. David Waldstreicher. 1787, rpt. Bedford, MA.: ST Martin's, 2002.

Lugenbeel, James W. Sketches of Liberia: Comprising a Brief Account of the Geography, Climate, Productions, and Diseases, of the Republic of Liberia. Washington D. C.: C. Alexander, 1850.

McGraw, Marie, T. "Richmond Free Blacks and African Colonization, 1816-1832." Journal of American Studies 21 (1987): 207-224.

Miller, Randall M., ed. "Dear Master": Letters of a Slave Family. Ithaca: Cornell University Press, 1978.

Morris, Edward S. An Address Before the Liberia Union Agricultural Enterprise Co: At Clay Ashland on the St. Paul's River Philadelphia: WM. S. Young, 1863.

Moses, Wilson, Jeremiah., ed. Liberian Dreams: Back-to-Africa Narratives from the 1850s. Pennsylvania: The University of Pennsylvania State University, 1998.

Shick, Tom W. "Emigrants to Liberia, 1820 to 1843: An Alphabetical Listing. Liberian Studies." Liberian Studies Research Working Paper No. 2. Newark, Del.: Department of Anthropology, University of Delaware, 1971.

. "A Quantitative Analysis of Liberian Colonization from 1820 to 1843 with Special Reference to Mortality." Journal of African History 12, 1 (1971): 45-59.

Smith, W. W. ed. "A Marylander in Africa: The letters of Henry Hannon." Maryland Historical Magazine 69, 4 (1974): 398-404.

Stockham, George and Edward Morris. Liberia Coffee. Philadelphia: Edward Morris, 1887.

Thomas, Charles W. Adventures and Observations on the West Coast of Africa, and Its Islands. Mobile: John F. Early, 1860.

Washington, Booker T. Up From Slavery: An Autobiography. Williamstown, MA.: Corner House, 1989. 
Wiley, Bell I., ed. Slaves no More: Letters From Liberia, 1833-1869. Lexington: The University of Kentucky, 1980.

Winterbottom, Thomas. An Account of the Native Africans in the Neighborhood of Sierra Leone: To Which is Added An Account of the Present State of Medicine Among Them. Vol. 1, rpt. Frank Case \& Co., 1969.

Secondary Sources

Ahn, Peter M. West African Soils, vol. 1. Oxford: Oxford University, 1970.

Ajayi, J. F. Ade \& Michael Crowder. History of West Africa, Volume Two. New York:Columbus University, 1973.

Akpan, M. B. "Black Imperialism: Americo-Liberian Rule Over the African Peoples of Liberia, 1847-1964." The Canadian Journal of African Studies 7, 2 (1973): 217-236.

. "The Liberian Economy in the Nineteenth Century: The State of Agriculture and Commerce." Liberian Studies Journal 6, 1 (1975): 1-24.

Allison, P.A. "Historical Inferences to be Drawn From the Effect of Human Settlement on the Vegetation of Africa." Journal of African History 3 (1962): 241-249.

Ashburn, Frank D. ed. The Ranks of Death: A Medical History of the Conquest of America. New York: Coward-McCann, 1947.

Ashcroft, M. T. "The Importance of African Wild Animals as Reservoirs of Trypanosomiasis." East African Medical Journal 36, 6 (June 1959): 289-297.

Baker, Herbert G. Plants and Civilization. Belmont, California: Wadsworth Publishing Company, 1970.

Billington, Ray A. "The American Frontier." In Beyond the Frontier, edited by Paul Bohannan and Fred Plog, 3-24. New York: Natural History, 1967.

Blyden, Nematta Amelia. West Indies in West Africa, 1808-1880: The African Diaspora in Reverse. New York: University of Rochester Press, 2000.

Bohannan, Paul and Philip Curtin, Africa and Africans. Prospect Heights, IL: Waveland Press, 1995.

Boserup, Esther. The Conditions of Agricultural Growth. London: Faber, 1965.

Boubacar Barry. Senegambia and the Atlantic Slave Trade. New York: Cambridge University Press, 1998. 
Braudel, Fernand. On History. Chicago: The University of Chicago, 1980.

Broderick, Cyril E. "Liberian Agriculture: History and Status Toward the Twenty-first Century.” Liberian Studies Journal 23, 1 (1998): 42-76.

Brooks, George E. "The Kru Mariner in the Nineteenth century: An Historical Compendium." Liberian Studies Association in America, Newark, Delaware, 1972.

. "Peanuts and Colonialism: Consequences of the Commercialization of Peanuts in West Africa, 1830-70.” Journal of Africa History 16, 1 (1975): 29-54.

. Landlord and Strangers: Ecology, Society, and Trade in West Africa, 1000-1630. Boulder, CO.: Westview, 1993.

Brown, George W. The Economic History of Liberia. Washington, D. C.: Associated Press, 1941.

Brown, Peter. "Malaria, Miseria, and Underdevelopment in Sardinia: The Malaria Blocks Development Cultural Model." Medical Anthropology 17 (1977): 239-254.

Campbell, Penelope. Maryland in Africa: The Maryland State Colonization Society 18311857. Urbana: University of Illinois, 1971.

Carney, Judith A. Black Rice: The African Origins of Rice Cultivation in the Americas. Cambridge, MA: Harvard University Press, 2001.

Christaller, Walter. Central Places in Souther Germany. Translated by Carlisie W. Baskin. Englewoods Cliffs, NJ.: Prinetice-Hall, 1966.

Clower, Robert W.; Dalton, G.; Harwitz, M.; and Walters, A. Growth Without Development: An Economic Survey of Liberia. Evanston: Northwestern University, 1966.

Cobley, Leslie S. An Introduction to the Botany of Tropical Crops. New York: Longman Inc., 1976.

Cook, Noble D. Born to Die: Disease and New World Conquest, 1492-1650. New York: Cambridge University, 1998.

Cooper, Frederick. From Slaves to Squatters: Plantation Labor and Agriculture in Zanzibar and Coastal Kenya, 1890-1925. Portsmouth, NH: Heinemann, 1997.

Cordell, Dennis D. and Gregory, Joel W. ed. African Population and Capitalism: Historical Perspectives. Boulder, CO: Westview, 1987. 
Cronon, William. Nature's Metropolis: Chicago and the Great West. New York: W. W. Norton, 1991.

Crosby, Alfred W. The Columbian Exchange: Biological and Cultural Consequences of 1492. Westport, Conn.: Greenwood, 1972.

. Ecological Imperialism: The Biological Expansion of Europe, 900-1900. New York: Cambridge, 1986.

."Virgin Soil Epidemics as a Factor in the Aboriginal Depopulation in America." The William and Mary Quarterly $3^{\text {rd }}$ series 33 (April 1976): 289-99.

Curtin, Philip, D. The Image of Africa, British Ideas and Action, 1780-1850. Madison: University of Wisconsin, 1964

. Death By Migration: Europe's Encounter With the Tropical World in the Nineteenth Century. New York: Cambridge, 1989.

."The End of the White's Grave? Nineteenth-Century Mortality in West Africa." Journal of Interdisciplinary History 21, 1 (1990): 63-88.

.The Rise and Fall of the Plantation Complex: Essays in Atlantic History. New York: Cambridge University Press, 1990.

. Disease and Empire: The Health of European Troops in the Conquest of Africa. New York: Cambridge, 1998.

Curtin, Philip D., S. Feierman, L. Thompson and J. Vansina, African History: From the Earliest Times to the End of the Colonial Period. London: Longman, 1994.

Davidson, Basil. The Search for Africa: History, Culture, Politics. New York: Times Books, 1994.

The Department of Planning and Economics Affairs. July, 1968. The 1967 Agricultural Survey in Bong County. Monrovia, Liberia.

Diamond, Jared. Guns, Germs, and Steel: The Fates of Human Societies. New York: W. W. Norton, 1999.

Dicum, Gregory and Nina Luttinger. The Coffee Book: Anatomy of an Industry from Crop to the Last Drop. New York: The New Press, 1999. 
Dorward, D. C. and A. I. Payne. "Deforestation, the Decline of the Horse and the Spread of the Tsetse Fly and Trypanosomiasis (NAGANA) in Nineteenth Century Sierra Leone." Journal of African History 16 (1975): 239-25

Dunn, Richard. Sugar and Slaves: The Rise of the Planter Class in the English West Indies, 1624-1713. New York: W. W. Norton, 1973.

Elkins, Stanley M. Slavery: A Problem in American Institutional and Intellectual Life. Chicago: University of Chicago, 1969.

Ellis, Stephen. The Mask of Anarchy: The Destruction of Liberia and the Religious Dimension of an African Civil War. New York: New York University, 1999.

Davies, K. G. "The Living and the Dead: White Mortality in West Africa, 1732-1884." In Race and Slavery in the Western Hemisphere: Quantitative Studies, edited by Stanley Engerman and Eugene Genovese, 83-98. New Jersey: Princeton University Press 1975.

Fage, J. D. A History of Africa. New York: Routledge, 1995.

Ferry-Swainson, Kate. Ginger. Boston: Tuttle Publishing, 2000.

Fetter, Bruce. ed. Demography From Scanty Evidence: Central Africa in the Colonial Era. Boulder, CO: Lynne Rienner, 1990.

Fogel, Robert F. and Stanley Engerman. Time on the Cross: The Economics of American Negro Slavery. Boston: Little Brown, 1974.

Ford, John. The Role of the Trypanosomiases in African Ecology: A Study of the Tsetse Fly Problem. Oxford: Oxford University, 1971.

Foster, C. J. "The Colonization of Free Negroes in Liberia, 1816-35." Journal of Negro History, 38 (1953): 41-67.

Foster, Stanely O. "Malaria in Pregnant African Women: Epidemiology, Practice, Research, and Policy." American Journal of Tropical Medicine and Hygiene 55 (1996):1.

Frankenberger, Timothy R., John A. Lichte, Arthur S. Gedeo, John Kpakolo Jallah, Maran J. Sherman. Farming Systems Research in Three Counties in Liberia: A Reconnaissance Survey in Grand Gedeh, Nimba, and Bong Counties. Supported by the Farming Systems Support Project, University of Florida, with Cooperation from: the University of Kentucky, USAID/Monrovia, and Central Agricultural Research Institute, Suakoko, Liberia, April 1985. 
Franklin, John H. From Slavery to Freedom: History of American Negroes. New York: Alfred A.Knopf, 1947.

Fredrickson, George, M. The Arrogance of Race: Historical Perspective on Slavery, Racism, and Social Inequality. Middleton, CT.: Wesleyan University, 1988.

Frenkel, Stephen and John Western. "Pretext or Prophylaxis? Racial Segregation and Malarial Mosquitos in a British Tropical Colony: Sierra Leone." Annals of the Association of American Geographers 78, 2 (1988): 211-228.

Freund, Bill. The Making of Contemporary Africa: The Development of African Society Since 1800. Bloomington: Indiana University Press, 1984.

Fyfe, Christopher. A History of Sierra Leone. Oxford, UK: Oxford University, 1962.

Genovase, Eugene D. The Political Economy of Slavery: Studies in the Economy and Society of the Slave South. New York: Vantage Books, 1967.

. Roll, Jordan Roll: The World the Slaves Made. New York: Pantheon Books, 1974.

Gibbs, James L. "The Kpelle of Liberia," in Peoples of Africa, ed. James L. Gibbs. New York: Holt, Rinehart and Winston, 1965.

Gnielinski, Stefon Von, ed. Liberia in Maps. New York: Africana Publishing Corporation, 1972.

Goe, Michael R. and Robert E. McDowell. Animal Traction: Guidelines for Utilization. New York: Cornell International Agriculture Mimeograph, Cornell University, 1980.

Haggett, Peter. Geography: A Modern Synthesis. New York: Harper \& Row, n.d.

Hammond, Dorothy and Alta Jablow. The Myth of Africa. New York: The Library of Social Science, 1977.

Hargreaves, J. D. "African Colonization in the Nineteenth Century: Liberia and Sierra Leone." Sierra Leone Studies 16 (1962): 189-203.

Harley, George W. "Notes on the Poro in Liberia," Papers of the Peabody Museum of American Archaeology and Ethnography, 19 (1941).

Hartwig, Gerald W. and K. David Patterson, eds. Disease in African History: An Introductory Survey and Case Study. Durham, NC: Duke University, 1978. 
Hillard, Sam B. Hog Meat and Hoecake: Food Supply in the Old South, 1840-1860. Carbondale: Southern Illinois University, 1972.

Hilty, Hiram, H. Toward Freedom For All: North Carolina Quakers and Slavery. Richmond, IN: Friends United Press, 1984.

Hoeppli, R. Parasitic Diseases in Africa and the Western Hemisphere: Early Documentation and Transmission by the Slave Trade. Verlag Fürrecht Und Gesellschaft AG. Basel, 1969.

Hogendorn, Jan S. Nigerian Groundnut Exports: Origins and Early Development. Zaria, Nigeria: Ahmadu Bello University Press, 1978.

Holsoe, Svend E. "The Condo Confederation in Western Liberia." Liberian Historical Review 3, (1966): 1-28.

"A Study of Relations Between Settlers and Indigenous Peoples in Western Liberia, 1821-1847.” African Historical Studies 4, 2 (1971): 331-362.

. "The Manding in Western Liberia: An Overview." Liberian Studies Journal 7, 1 (1976-77): 1-12.

. "Economic Activities in the Liberian Area: The Pre-European Period to 1900." In Essays on the Economic Anthropology of Liberia and Sierra Leone, edited by Vernon R. Dorjahn and Barry L Isaac, 63-78. Philadelphia: Institute for Liberian Studies, 1979.

Holsoe, Svend E. and Bernard L. Herman. A Land and Life Remembered: AmericoLiberian Folk Architecture. Athens: University of Georgia, 1988.

Holt, Thomas C. The Problem of Freedom: Race, Labor, and Politics in Jamaica and Britain, 1832-1938. Baltimore: The Johns Hopkins University Press: 1992.

Hopkins, A. G. An Economic History of West Africa. New York: Columbia University, 1973.

Huberich, Charles, H. The Political and Legislative History of Liberia, vol. 1. New York: Central Books, 1947.

James, C. L. R. The Black Jacobins: Toussaint Louverture And The San Domingo Revolution. New York: Dial Press, n.d.

Jenne, Theodore. Agriculture in Liberia: Realities, Problems and Potentials. HRSG.: Institut Für Regionalwissenschaft der Universität Karlsruhe, 1982. 
Johnston, Harry. Liberia, vol. 1. London: Hutchinson \& Co., 1906.

Jones, Adam. From Slaves to Palm Kernels: A History of the Galinhas Country, West Africa, 1730-1890. Franz Steiner Verlag Gmbh. Wiesbaden, 1983.

Kiple, Kenneth F. Another Dimension of the Black Diaspora: Diet, Disease, and Racism. New York: Cambridge University, 1981.

Klein, Herbert S. African Slavery in Latin American and the Caribbean. New York: Oxford University, 1986.

Kopytoff, Igor, ed. The African Frontier: The Reproduction of Traditional African Societies. Bloomington: Indiana University, 1987.

Khun, Thomas S. The Structure of Scientific Revolutions. Chicago: University of Chicago Press, 1970.

Law, Robin, ed. From Slave Trade to 'Legitimate' Commerce: The Commercial Transition in Nineteenth-century West Africa. New York: Cambridge University Press, 1995.

.The Horse in West African History: The Role of the Horse in the Societies of Pre-colonial West Africa. London: Oxford University, 1980.

Liberty, C. E. Zamba. "Growth of the Liberian State: An Analysis of the Historiography.”Ph.D. diss., Department of History, Stanford University, 1977.

Liebenow, J. Gus. Agriculture, Education, and Rural Transformation-with particular reference to East Africa. Bloomington: Department of Political Science, 1969. 1969. . Liberia: The Evolution of Privilege. Ithaca, N.Y.: Cornell University Press, 1987. . Liberia: The Quest for Democracy. Bloomington: Indiana University Press,

Lynch, Hollis R. Edward Wilmot Blyden: Pan-Negro Patriot, 1832-1912. London: Oxford University Press, 1967.

Lynn, Martin. Commerce and Economic Change in West Africa: The Palm Oil Trade in the Nineteenth Century. London: Cambridge Press, 1997.

Maxon, Robert M. East Africa: An Introductory History. Morgantown, WA: West Virginia University Press, 1994. 
Magdol, Edward. A Right to Land: Essays on the Freedmen's Community. Westport: Greenwood Press, 1977.

McDaniel, Antonio. Swing Low, Sweet Chariot: The Mortality Cost of Colonizing Liberia in the Nineteenth Century. Chicago: University of Chicago Press, 1993.

McNeil, William H. Plagues and Peoples. New York: Anchor Books, 1998.

Miers, Suzanne and Igor Kopytoff, eds. Slavery in Africa: Historical and Anthropological Perspectives. Madison: University of Wisconsin Press 1977.

Miller, Floyd. The Search for a Black Nationality: Black Emigration and Colonization, 1787-1863. Chicago: University of Illinois, 1975.

The Ministry of Agriculture, Liberia. "The Liberian Farmer." 3, 1 (1998).

Mintz, Sidney W. Sweetness and Power: The Place of Sugar in Modern History. New York: Penguin Books: 1986.

. "Tasting Food, Tasting Freedom." In Slavery in the Americas, edited by Wolfang Binder, 257-275. Germany: Königshausen, 1993.

Moore, Sally Falk. Anthropology and Africa: Changing Perspectives on a Changing Scene. Charlottesville, WA: The Press of University of Virginia, 1994.

Morgan, W. B. "The Forest and Agriculture in West Africa." Journal of African History 3 (1962): 235-239.

Nash, Gary B and J. R. Soderlund. Freedom by Degrees: Emancipation in Pennsylvania and its Aftermath. New York: Oxford University Press, 1991.

Neumann, Roderick P. Imposing Wilderness: Struggles over Livelihood and Nature Preservation in Africa. Berkeley, CA: University of California Press, 2002.

Newman, Debra L. "Laborers Into the Harvest: Liberian Working Women in the Nineteenth Century." Liberia-Forum 4, 7 (1988): 36-50.

Norton, Mary B.; Katzman, D.; Escott, P.; Chudacoff, H.; Paterson, T.; Tuttle, W.; and Brophy, W. A People and a Nation: A History of the United States. Boston: Houghton Mifflin, 1999.

Obatala, J. K. "Liberia: The Meaning of Dual Citizenship." The Black Scholar 4, 10 (1973): 16-19. 
Orton, Clayton R. Agriculture in Liberia. United States Foreign Operations Administration, Department of Agriculture, 1954.

Pampana, Emilio. A Textbook of Malaria Eradication. London: Oxford University Press, 1969.

Pendergrast, Mark. Uncommon Grounds: The History of Coffee and How it Transformed Our World. New York: Basic Books, 1999.

Pereira-Lunghu, Jacob M. "Agricultural Policy and Performance in Liberia (1920-1990): Implications for Policy in Post-Civil War Liberia." Africa Development, 23 (1998): 127-142.

Phillips, Ulrich B. The Slave Economy of the Old South. Edited by Eugene Genovese. Baton Rouge: Louisiana State University, 1968.

Redkey, Edwin, S. Black Exodus: Black Nationalist and Back-to-Africa Movements, 1890-1910. New Haven: Yale University, 1969.

Richards, Paul. Indigenous Agricultural Revolution. Boulder, CO: Westview Press, 1985.

Richardson, Nathaniel R. Liberia's Past and Present. London: Diplomatic Press and Publishing Co., 1959.

Rodney, Walter. A History of the Guyanese Working people, 1881-1905. Baltimore: John Hopkins, 1981.

Ruthenberg, Hans. Farming Systems in the Tropics. Oxford: Clarendon, 1971.

Saha, Santosh C. A History of Agriculture in Liberia, 1822-1970: Transference of American Values. Lewiston: Edwin Mellen, 1990.

Sawyer, Amos. The Emergence of Autocracy in Liberia: Tragedy and Challenges. San Francisco: Institute for Contemporary Studies, 1992.

Shick, Tom W. Behold the Promised Land: A History of Afro-American Settler Society in Nineteenth-Century Liberia. Baltimore, MD.: John Hopkins University, 1981.

Sibley, James. Liberia Old and New: A Study of its Social and economic Background with Possibilities for Development. Garden, New York: N. P., 1928.

Simpson, C. L. The Memoirs of C. L. Simpson: The Symbol of Liberia. London: The Diplomatic Press and Publishing Co., 1961. 
Sitterson, J. C. Sugar Cane Country: The Cane Sugar Industry in the South, 1753-1950. Lexington: University of Kentucky, 1973.

Smith, Dale C. "Quinine and Fever: The Development of the Effective Dosage." Journal of the History of Medicine and Allied Sciences 31 (1976): 343-367.

Stampp, Kenneth. The Peculiar Institution: Slavery in the ante-bellum South. New York: Knopf, 1956.

Staudenraus, P. J. The African Colonization Movement: 1816-1865. New York: Octagon Books, 1980.

Stoianivich, T. French Historical Method: The Annales Paradigm. Ithaca, N.Y.: Cornell University, 1976.

Strong, Richard P., ed. The African Republic of Liberia and the Belgian Congo: Harvard African Expedition, 1926-1927, vol. 1. New York: Cambridge University, 1930.

Sundiata, I. K. Black Scandal: America and the Liberian Labor Crisis, 1929-1936. Philadelphia: ISH, 1980.

Syfert, Dwight N. "The Origins of Privilege: Liberian Merchants, 1822-1847." Liberian Studies Journal 6 (1975): 109-28.

."The Liberian Coasting Trade, 1822-1900." Journal of African History 18, 2 (1977): 217-235.

Thomas, Lamont D. Paul Cuffe: Black Entrepreneur and Pan-Africanist. Urbana: University of Illinois, 1988.

Tiyambe, Zeleza. A Modern Economic History of Africa: The Nineteenth Century, vol. 1. Oxford: CODESRIA, 1993.

Turner, Frederick J. "The Significance of the Frontier in American History." In Frontier and Section: Selected Essays, edited by Ray A. Billington. Englewood Cliffs, N. J.: Prentice-Hall, 1961.

United States Department of Agriculture Cooperating With Agency for International Development. March 16-April 24, 1968. Rice Production and Marketing in Liberia.

Uribe, Compuzano Andrès. Brown Gold: The Amazing Story of Coffee. New York: Random House, 1954.

Vansina, Jan. Oral Tradition as History. London: James Curry, 1985. 
Warshaw, Leon. Malaria. Biography of a Killer. New York: Rinehart and Co., 1949.

Watkins, Melville H. "A Staple Theory of Economic Growth." The Canadian Journal of Economics and Political Science 24, 2 (May 1963): 141-158.

Webb, James. Desert Frontier: Ecological and Economic Change along the Western Sahel, 1600-1850. Madison: University of Wisconsin Press, 1995.

Webster, J. B. "The Bible and the Plough." Journal of the Historical Society of Nigeria 2, 4 (December 1963): 418-434.

Webster, J. B. and A. A. Boahen. History of West Africa: The Revolutionary Years-1815 to Independence. New York: Praeger Publishers, 1970.

West, Richard. Back to Africa: A History of Sierra Leone and Liberia. London: Jonathan Cape, 1970.

Wickizer, V. D. The World Coffee Economy: With Special reference to Control Schemes. Stanford: Stanford University, 1949.

Williams, Eric. Capitalism and Slavery. New York: Russell and Russell, 1961.

Wilmers, William E. "Secret Medicines, Magic and Rites of the Kpelle Tribe in Liberia," Southwestern Journal of Anthropology 5 (1949):208-243.

Wood, Corinne Shear. "New Evidence for a Late Introduction of Malaria into the New World." Current Anthropology 16, 1 (March 1975): 93-103.

Wyse, Akintola. The Krio of Sierra Leone: An Interpretive History. London: C. Hurst and Co., 1989.

Yoder, John. He Kill My Ma, He Kill My Pa, I Will Vote for Him: A Study of Political Culture, Civil Society and State Crisis in Liberia." Submitted for publication.

Young, James C. Liberia Rediscovered. Garden City, NY: Doubleday, Doran \& Co, 1934.

Young, Martin D., Don E. Eyles, Robert W. Burgess and Geoffrey M. Jeffery. "Experimental Testing of the Immunity of Negroes to Plasmodium Vivax," The Journal of Parisitology 41(1955): 315-318.

Zachernuk, Philip S. "Of Origins and Colonial Order: Southern Nigerian Historians and the Hamitic Hypothesis." Journal of African History 35, 3 (1994): 427-455. 


\section{WILLIAM EZRA ALLEN}

1983

B.A., History

University of Liberia

Monrovia, Liberia

1984-1987

Teaching Assistant

University of Liberia

Monrovia, Liberia

1989

M.A.T., Social Studies

Indiana University

Bloomington, Indiana

1990-1992

Adjunct Instructor

Atlanta Metropolitan College

Atlanta, Georgia

1993-1995

Instructor of History

Morris Brown College

Atlanta, Georgia

1996-1998

Teaching Assistant

Florida International University

Miami, Florida

1999

Rockefeller Research Fellow

Dissertation Research

Monrovia, Liberia

2000

Teaching Assistant

Florida International University

Miami, Florida

PRESENTATIONS AND PUBLICATIONS

Clarence-Smith, William Gervase (ed.) "Cocoa Pioneer Fronts Since 1800: The Role of Smallholders, Planters and Merchants.” New York: St. Martin's Press, 1996. P. 247. Journal of Third World Studies, XVI, 2(Fall, 1999). 
November 2000. "Collard Greens and Pigfoot, Palm Oil and Coffee: Evaluating the Evidence That Agriculture Was Neglected in $19^{\text {th }}$ Century Liberia." African Studies Association 43rd Annual Meeting, Nashville, Tennessee.

January 1999. "African Arts and African History: A Long Brush with the Past." University of Miami, The Lowe Arts Museum.

December 1999. "Demographic Significance in Liberian Commercial Agriculture, 18221843." Demographic Unit, University of Liberia, West Africa.

March 1998."Collard Greens, Pig Foot, and Coffee: A Historical Survey of Liberian Ecological History.” Liberian Studies Association Conference, Atlanta, GA. 